\title{
Gut-Pancreas-Liver Axis as a Target for Treatment of NAFLD/NASH
}

\author{
Gianluca Svegliati-Baroni ${ }^{1,2}$, Bárbara Patrício ${ }^{3,4,5}{ }^{\oplus}$, Gessica Lioci ${ }^{6}$, \\ Maria Paula Macedo $5,7,8, *$ (D) and Amalia Gastaldelli $3,4, *$ (D) \\ 1 Liver Injury and Transplant Unit, Ospedali Riuniti Ancona, 60020 Ancona, Italy; gsvegliati@gmail.com \\ 2 Obesity Center, Polytechnic University of Marche, 60121 Ancona, Italy \\ 3 Cardiometabolic Risk Unit, Institute of Clinical Physiology, CNR, 56124 Pisa, Italy; barbara_patricio@ifc.cnr.it \\ 4 Institute of Life Sciences, Sant' Anna School of Advanced Studies, 56127 Pisa, Italy \\ 5 APDP Diabetes Portugal, Education and Research Center (APDP-ERC), 1250-189 Lisbon, Portugal \\ 6 Department of Gastroenterology, Polytechnic University of Marche, 60121 Ancona, Italy; \\ gessicalioci@gmail.com \\ 7 CEDOC, NOVA Medical School/Faculdade de Ciências Médicas, Universidade Nova de Lisboa, \\ 1150-082 Lisboa, Portugal \\ 8 Department of Medical Sciences, Institute of Biomedicine-iBiMED, University of Aveiro, \\ 3810-193 Aveiro, Portugal \\ * Correspondence: paula.macedo@nms.unl.pt (M.P.M.); amalia@ifc.cnr.it (A.G.); \\ Tel.: +39-050-3152679/80 (A.G.)
}

Received: 1 July 2020; Accepted: 9 August 2020; Published: 13 August 2020

\begin{abstract}
Non-alcoholic fatty liver disease (NAFLD) represents the most common form of chronic liver disease worldwide. Due to its association with obesity and diabetes and the fall in hepatitis $\mathrm{C}$ virus morbidity, cirrhosis in NAFLD is becoming the most frequent indication to liver transplantation, but the pathogenetic mechanisms are still not completely understood. The so-called gut-liver axis has gained enormous interest when data showed that its alteration can lead to NAFLD development and might favor the occurrence of non-alcoholic steatohepatitis (NASH). Moreover, several therapeutic approaches targeting the gut-pancreas-liver axis, e.g., incretins, showed promising results in NASH treatment. In this review, we describe the role of incretin hormones in NAFLD/NASH pathogenesis and treatment and how metagenomic/metabolomic alterations in the gut microbiota can lead to NASH in the presence of gut barrier modifications favoring the passage of bacteria or bacterial products in the portal circulation, i.e., bacterial translocation.
\end{abstract}

Keywords: non-alcoholic fatty liver disease; non-alcoholic steatohepatitis; type-2 diabetes; gut-pancreas-liver axis; incretins; lipid metabolism; glucose metabolism

\section{Introduction}

The incidence of non-alcoholic fatty liver disease (NAFLD) is rapidly growing and it is estimated that in the general population about $25 \%$ of the individuals have hepatic steatosis [1]. The real prevalence of the disease is unknown, but it increases up to $57 \%$ in those with body mass index (BMI) of $30 \mathrm{~kg} / \mathrm{m}^{2}$ or greater (obesity), to $70 \%$ in diabetic subjects, and $90 \%$ in morbidly obese patients undergoing metabolic surgery [2,3].

The mechanisms that lead to hepatic triglyceride (TG) accumulation and the development of NASH are complex and still incompletely understood. It has been postulated that the initial accumulation of hepatic TG is a compensatory effect for hepatic lipid overflow without major metabolic effect (first hit). However, lipotoxicity and other factors are triggering hepatic inflammation and tissue fibrosis that can lead to non-alcoholic steatohepatitis (NASH, second hit) [4]. Several hypotheses 
have been postulated as regard to the second hit, including the involvement of an alteration in the gut-liver axis [5]. The intestine is a multifunctional organ connected with many body organs but its role in metabolism control was only revealed in recent years. The intestinal cells secrete several hormones-among these glucagon-like peptide-1 (GLP-1), glucose-dependent insulinotropic peptide (GIP), oxyntomodulin and possibly glucagon - that are involved with pancreatic hormones insulin and glucagon and are important for the maintenance of glucose and lipid homeostasis [6]. Moreover, the gut microbiota can influence whole body and liver metabolic and inflammatory status through the metabolism of nutrients and the release of anti- and pro-inflammatory compounds. The intestinal barrier might become compromised allowing bacterial translocation from the intestine to other organs (the liver in primis). The aim of this review is to discuss some of the mechanisms involved in the gut-pancreas-liver axis important for the development of NAFLD and its progression to NASH and other comorbidities like type-2 diabetes (T2D).

\section{Physiological Effects of Incretin Hormones}

It is now recognized that the intestine is an endocrine organ able to secrete hormones that regulate whole-body metabolism in response to food ingestion and also to regulate appetite and gastric emptying. Among these hormones, the most studied are the incretin hormones like GLP-1 and GIP that are secreted mainly by the intestine in response to a meal [7] (Figure 1).

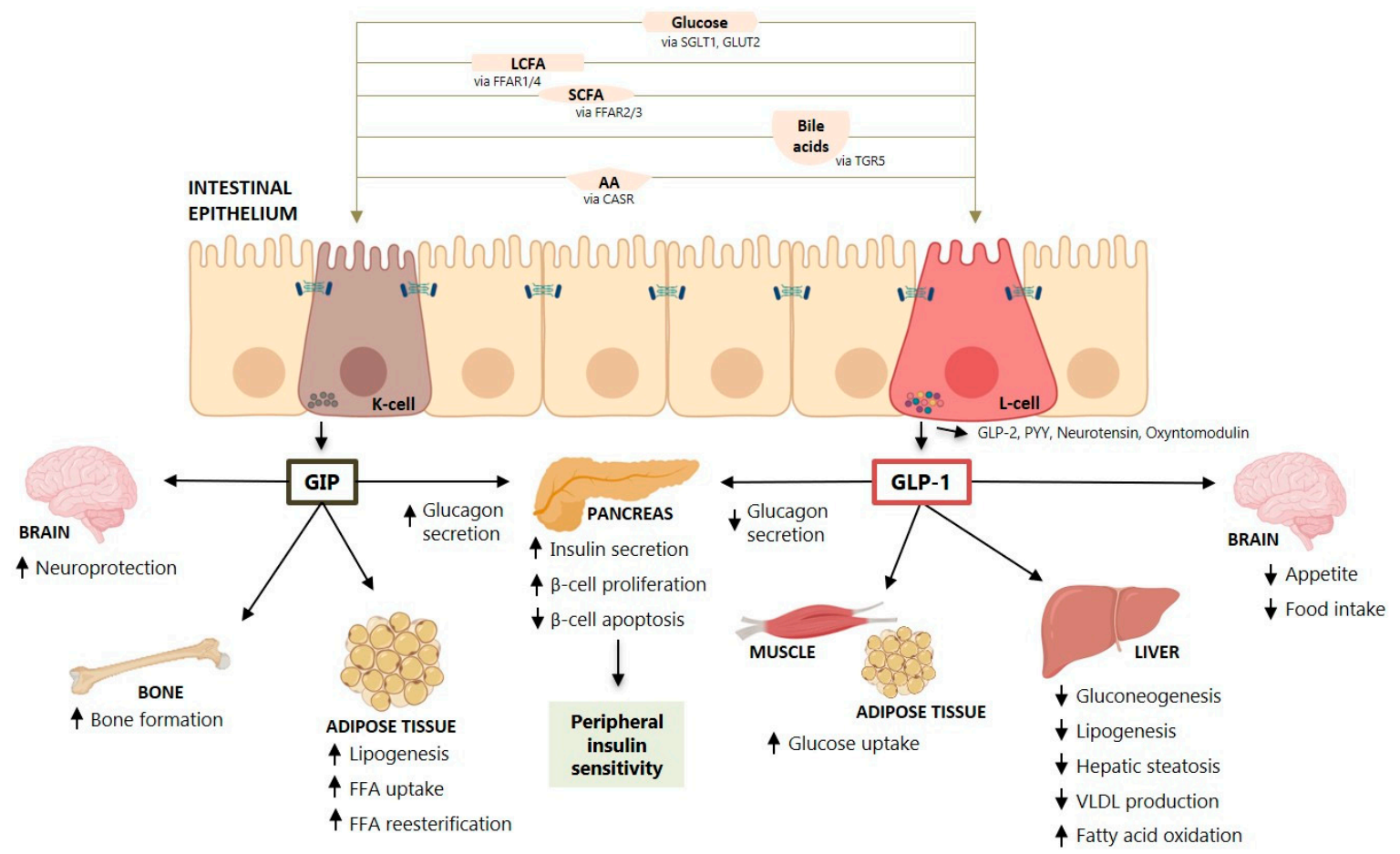

Figure 1. Secretion and physiological effects of incretin hormones GIP and GLP-1 in different organs and tissues. The intestinal epithelium is composed of several cell types, including enteroendocrine cells such as K-cells and L-cells, responsible for the secretion of GIP and GLP-1, respectively. The secretion of these hormones is triggered upon nutrient stimulation of G protein-coupled receptors (GPCRs) present in the cell membrane. Some of the nutrients responsible for GIP and GLP-1 secretion are glucose (and other carbohydrates), lipids, some amino acids and proteins. Bile acids can also stimulate incretin secretion. After secretion, GIP and GLP-1 exert their functions in the pancreas and extra-pancreatic tissues, such as the liver, adipose tissue, muscle, bone, and the central nervous system. Abbreviations: AA, Amino acids; CASR, Calcium-sensing receptor; FFAR, Free fatty acid receptor; GIP, Glucose-dependent insulinotropic peptide; GLP-1, Glucagon-like peptide-1; GLP-2, Glucagon-like peptide-2; GLUT, Glucose transporter; LCFA, Long-chain fatty acids; PYY, Peptide YY; SCFA, Short-chain fatty acids; SGLT, Sodium-dependent glucose cotransporter; TGR5, Takeda G protein-coupled receptor 5; VLDL, Very-low-density lipoprotein. 
After secretion, gut hormones are rapidly degraded by dipeptidyl peptidase-4 (DPP-4), resulting in an in vivo half-life of approximately two minutes. DPP-4 is a 110 kilodaltons (kDa) membrane-associated peptidase that is expressed on the apical surface of epithelial and acinar cells, endothelial cells, fibroblasts, and lymphocytes [8-10] and also exists as a soluble circulating form in plasma [11]. For this reason, synthetic forms of GLP-1 resistant to the action of DPP-4 (exenatide, liraglutide, lixisenatide, albiglutide, dulaglutide, semaglutide) or inhibitors of DPP-4 activity (e.g., gliptins) have been developed and commercialized in order to raise the plasma levels of GLP-1.

\subsection{Incretin Secretion and Physiological Effects}

The secretion of the incretin hormones GLP-1 and GIP occurs in the intestine in response to a meal [7] (Figure 1). Nutrients in a meal, such as glucose, fatty acids and triglycerides, amino acids and proteins stimulate incretin hormone secretion in the intestine [12]. Some studies showed that pancreatic alpha cells may also secrete GLP-1 [13]. The major effect of incretins is the potentiation of glucose-stimulated insulin secretion by pancreatic $\beta$-cells [14-17]. Despite similar effects on insulin secretion, GLP-1 and GIP have opposite effects on glucagon secretion by pancreatic $\alpha$ cells. While GLP-1 suppresses glucagon secretion at euglycemia, but not during hypoglycemia [18], GIP stimulates glucagon secretion at euglycemia, but not during hyperglycemia [19], being one of the reasons behind the apathy for GIP-based therapies for T2D. The early studies by Nauck and Holst have shown that the actions of GLP-1 and GIP on insulin secretion are nearly equal and additive in healthy humans [20,21], which is not observed in the set of T2D where the endocrine pancreas ceases responsiveness to GIP but remains responsive to GLP-1, explaining the reduced/absent incretin effect of GIP in T2D [22,23].

GLP-1 also has other pleiotropic effects (Figure 1), including delay in gastric emptying and glucose absorption [24,25], stimulation of brain areas involved in the regulation of glucose homeostasis and food reward [26], suppression of glucagon secretion [25], beneficial effects on cardiovascular risk factors, a natriuretic effect on the kidney and others [16,27]. Of importance, GLP-1 has been shown to have a central effect to promote satiety, to reduce appetite and food intake [28], and GLP-1 receptor agonists (GLP-1RA) have been shown to promote weight loss and decrease liver fat $[28,29]$ (Figure 1). GIP is also an incretin hormone but its power to stimulate insulin secretion was considered minor compared to GLP-1 [20]. A recent study showed that GIP's effects on glucose excursions and insulin secretion in response to a four-hour oral glucose tolerance tests $(75 \mathrm{~g})$ combined with an ad libitum meal test were more relevant than GLP-1's effects (i.e., higher postprandial plasma glucose excursions and lower insulin secretion) and that the two hormones contribute additively to postprandial glucose regulation in healthy individuals [30]. Secretion of these two hormones is altered by obesity, age, diabetes, weight loss and exercise [31-33]. However, the pleiotropic effects of GLP-1 and GIP seem to be directed to different organs (Figure 1), such as the adipose tissue, muscle, central nervous system, bone and the liver.

\subsection{Incretin Effects on Liver Enzymes, Steatosis, Inflammation and Fibrosis}

The long-term effects of GLP-1RA go beyond the improvement in glucose metabolism and weight loss [34-39] and it is now established their beneficial effects of hepatic metabolism and histology. Only a limited number of studies have evaluated in humans the impact of GLP-1RA or DPP-4 inhibitors on liver function and hepatic steatosis (Tables 1 and 2). In general, a reduction in hepatic TG content has been observed with GLP-1RA. All GLP-1RA have shown an improvement in liver enzymes that was more evident in subjects with elevated alanine aminotransferase (ALT) at baseline. 
Table 1. Drugs with known effect on parameters of NAFLD/NASH (divided by the clinical trial phase).

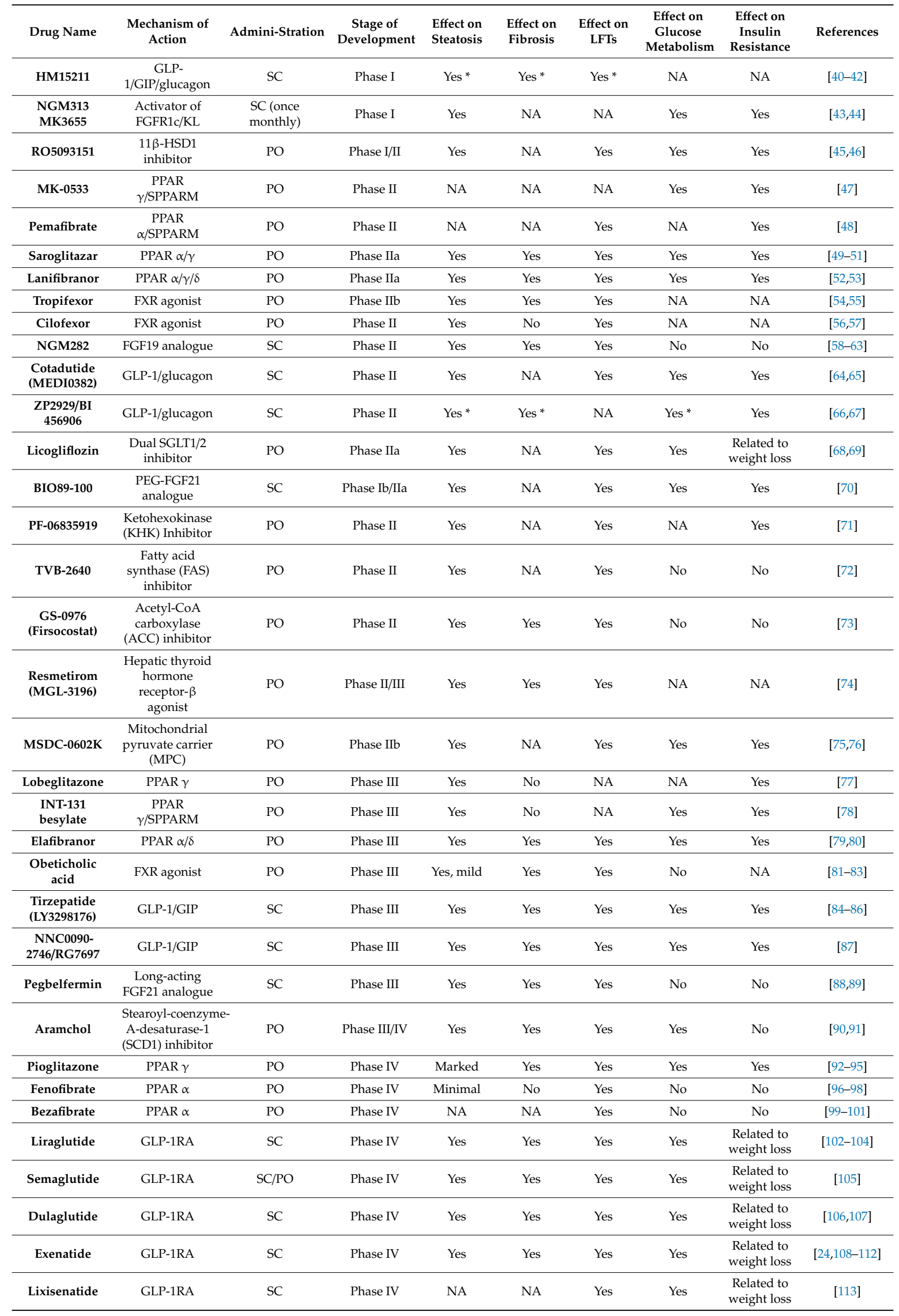


Table 1. Cont.

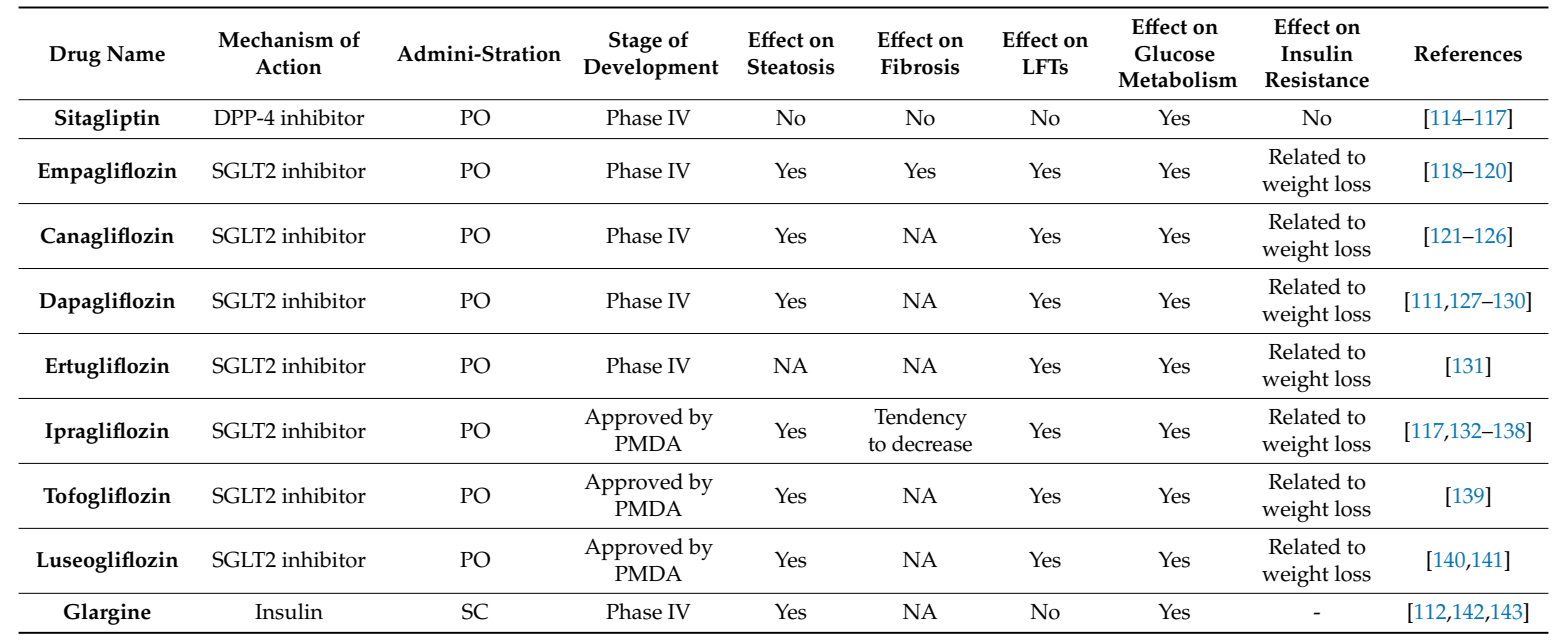

Only drugs approved or under investigation in clinical trials were reported. Abbreviations: ACC, Acetyl-CoA carboxylase $\alpha$; DPP-4, Dipeptidyl peptidase 4; FAS, Fatty acid synthase; FGF, Fibroblast growth factor; FGFR1c/KLB: fibroblast growth factor receptor 1c/ $\beta$ Klotho complex; FXR, Farnesoid X receptor; GIP, Glucose-dependent insulinotropic peptide; GLP-1, Glucagon-like peptide-1; GLP-1RA, Glucagon-like peptide-1 receptor agonists; HSD1, Hydroxysteroid dehydrogenase; KHK, Ketohexokinase; MPC, Mitochondrial pyruvate carrier; NA, Not available; PEG, PEGylated molecule attached to polyethylene glycol (PEG); PMDA, Pharmaceuticals and Medical Devices Agency; PO, Oral administration; PPAR, Peroxisome proliferator-activated receptor; SC, Subcutaneous administration; SCD1, Stearoyl-CoA desaturase 1; SGLT, Sodium-dependent glucose cotransporter; SPPARM, Selective PPAR $\gamma$ modulator. * Any changes in histological parameters were published only for preclinical studies (especially for the studies in phase 1).

Table 2. Liver-related outcome effects of treatment with GLP-1RA or DPP-4 inhibitors in humans.

\begin{tabular}{|c|c|c|c|c|c|c|c|c|c|c|}
\hline References & Subjects & $\begin{array}{l}\text { Weeks of } \\
\text { Treatment }\end{array}$ & Treatment Agent & $\begin{array}{l}\text { Histology } \\
\text { (Yes/No) }\end{array}$ & Fibrosis & Steatosis & $\begin{array}{l}\text { Visceral } \\
\text { Fat }\end{array}$ & ALT & BMI & HbA1c \\
\hline $\begin{array}{l}\text { Buse et al. } \\
\text { (2007) [144] }\end{array}$ & $\mathrm{T} 2 \mathrm{D}(n=283)$ & $\begin{array}{l}30+2 \text { years } \\
\text { follow up }\end{array}$ & Exenatide & No & - & - & - & $\begin{array}{c}\downarrow \\
\text { (if elevated } \\
\text { at baseline) }\end{array}$ & $\downarrow$ & $\downarrow$ \\
\hline $\begin{array}{l}\text { Klonoff et al. } \\
\text { (2008) [110] }\end{array}$ & $\mathrm{T} 2 \mathrm{D}(n=217)$ & $\begin{array}{l}30+3 \text { years } \\
\text { follow up }\end{array}$ & Exenatide & No & - & - & - & $\begin{array}{c}\downarrow \\
\text { (if elevated } \\
\text { at baseline) }\end{array}$ & $\downarrow$ & $\downarrow$ \\
\hline $\begin{array}{l}\text { Kenny et al. } \\
\text { (2010) [146] }\end{array}$ & $\begin{array}{c}\text { T2D and } \\
\text { biopsy-proven } \\
\text { NAFLD }(n=8)\end{array}$ & 28 & Exenatide & Yes & $\downarrow$ & $\downarrow$ & - & $\downarrow$ & $\downarrow$ & $\downarrow$ \\
\hline $\begin{array}{c}\text { Sathyanarayana } \\
\text { et al. (2011) } \\
{[147]}\end{array}$ & $\mathrm{T} 2 \mathrm{D}(n=21)$ & 52 & $\begin{array}{l}\text { Exenatide + } \\
\text { Pioglitazone }\end{array}$ & No & - & $\begin{array}{c}\downarrow \\
\text { (MRS) }\end{array}$ & - & $\downarrow$ & $\downarrow$ & $\downarrow$ \\
\hline $\begin{array}{l}\text { Ohki et al. } \\
\text { (2012) [149] }\end{array}$ & $\begin{array}{l}\text { T2D and NAFLD } \\
\quad(n=36)\end{array}$ & NA & Sitagliptin & No & $\begin{array}{c}= \\
\text { (APRI) }\end{array}$ & - & - & $\downarrow$ & $=$ & $\downarrow$ \\
\hline $\begin{array}{l}\text { Cuthberson et } \\
\text { al. (2012) [150] }\end{array}$ & $\begin{array}{c}\text { Obese, T2D and } \\
\text { NAFLD }(n=25 \\
19 / 6)\end{array}$ & 26 & $\begin{array}{l}\text { Exenatide or } \\
\text { Liraglutide }\end{array}$ & No & - & $\begin{array}{c}\downarrow \\
\text { (MRS) }\end{array}$ & $\stackrel{\downarrow}{(\mathrm{MRI})}$ & $\downarrow$ & $\downarrow$ & $\downarrow$ \\
\hline $\begin{array}{c}\text { Fan et al. (2013) } \\
{[151]}\end{array}$ & $\begin{array}{l}\text { T2D and NAFLD } \\
\quad(n=117)\end{array}$ & 12 & $\begin{array}{l}\text { Exenatide or } \\
\text { Metformin }\end{array}$ & No & - & - & - & $\downarrow$ & $\downarrow$ & $=$ \\
\hline $\begin{array}{l}\text { Suzuki et al. } \\
\text { (2013) [152] }\end{array}$ & $\mathrm{T} 2 \mathrm{D}(n=46)$ & 26 & $\begin{array}{l}\text { Liraglutide + } \\
\text { Pioglitazone }\end{array}$ & No & - & $\begin{array}{c}\downarrow \\
(\mathrm{CT})\end{array}$ & $\begin{array}{c}\downarrow \\
(\mathrm{CT})\end{array}$ & - & $\downarrow$ & $=$ \\
\hline $\begin{array}{l}\text { Bergenstal et al. } \\
\text { (2013) [153] }\end{array}$ & $\mathrm{T} 2 \mathrm{D}(n=534)$ & 52 & Exenatide & No & - & - & - & $\downarrow$ & $\downarrow$ & $\downarrow$ \\
\hline
\end{tabular}


Table 2. Cont.

\begin{tabular}{|c|c|c|c|c|c|c|c|c|c|c|}
\hline References & Subjects & $\begin{array}{c}\text { Weeks of } \\
\text { Treatment }\end{array}$ & Treatment Agent & $\begin{array}{c}\text { Histology } \\
\text { (Yes/No) }\end{array}$ & Fibrosis & Steatosis & $\begin{array}{l}\text { Visceral } \\
\text { Fat }\end{array}$ & ALT & BMI & HbA1c \\
\hline $\begin{array}{l}\text { Watanabe et al. } \\
\text { (2015) [115] }\end{array}$ & $\begin{array}{l}\text { T2D and NAFLD } \\
(n=7)\end{array}$ & 12 & Sitagliptin & No & - & $\begin{array}{c}\downarrow \\
\text { (MRS) }\end{array}$ & $\begin{array}{c}= \\
(\mathrm{MRI})\end{array}$ & $=$ & $=$ & $\downarrow$ \\
\hline $\begin{array}{l}\text { Tang et al. } \\
\text { (2015) [142] }\end{array}$ & $\mathrm{T} 2 \mathrm{D}(n=35)$ & 12 & $\begin{array}{l}\text { Liraglutide or Insulin } \\
\text { glargine }\end{array}$ & No & - & $\begin{array}{c}= \\
(\mathrm{MRS})\end{array}$ & - & $=$ & $\downarrow$ & $\downarrow$ \\
\hline $\begin{array}{l}\text { Eguchi et al.* } \\
\text { (2015) [155] }\end{array}$ & $\begin{array}{c}\text { Diabetic } \\
\text { NAFLD/NASH } \\
(n=19)\end{array}$ & $24+24$ & $\begin{array}{c}\text { Lifestyle + } \\
\text { Liraglutide }\end{array}$ & No & $\stackrel{\downarrow}{\text { (FIB-4) }}$ & $\stackrel{\downarrow}{\downarrow}$ & $\stackrel{\downarrow}{(\mathrm{CT})}$ & $\downarrow$ & $\downarrow$ & $\downarrow$ \\
\hline $\begin{array}{l}\text { Eguchi et al.* } \\
\text { (2015) [155] }\end{array}$ & $\begin{array}{c}\text { T2D+ } \\
\text { NAFLD/NASH } \\
\quad(n=10)\end{array}$ & $24+24+96$ & $\begin{array}{c}\text { Lifestyle + } \\
\text { Liraglutide + } \\
\text { Follow-up } \\
\text { Liraglutide }\end{array}$ & Yes & $\downarrow$ & $\downarrow$ & - & $\downarrow$ & $\downarrow$ & $\downarrow$ \\
\hline $\begin{array}{l}\text { Smits et al. } \\
\text { (2016) [156] }\end{array}$ & $\begin{array}{l}\text { Overweight T2D } \\
\quad(n=52)\end{array}$ & 12 & $\begin{array}{l}\text { Liraglutide or } \\
\text { Sitagliptin }\end{array}$ & No & $\begin{array}{c}= \\
\text { (APRI/FIB- } \\
4 / \text { NFS) }\end{array}$ & $\begin{array}{c}= \\
(\mathrm{MRS})\end{array}$ & - & $\downarrow$ & $=$ & $\downarrow$ \\
\hline $\begin{array}{c}\text { Cui et al. (2016) } \\
\text { [114] }\end{array}$ & $\begin{array}{c}\text { Prediabetic } \\
\text { NAFLD }(n=50)\end{array}$ & 24 & Sitagliptin & No & $\begin{array}{c}= \\
(\mathrm{MRE})\end{array}$ & $\begin{array}{c}= \\
(\mathrm{MRI})\end{array}$ & - & $=$ & $=$ & $=$ \\
\hline $\begin{array}{l}\text { Armstrong et } \\
\text { al. (2016) [103] }\end{array}$ & $\begin{array}{l}\text { Biopsy-proven } \\
\text { NASH }(n=23)\end{array}$ & 48 & Liraglutide & Yes & $\downarrow$ & $\downarrow$ & - & $\downarrow$ & $\downarrow$ & $\downarrow$ \\
\hline $\begin{array}{c}\text { Joy et al. (2017) } \\
\text { [116] }\end{array}$ & $\begin{array}{l}\text { Biopsy-proven } \\
\text { NASH }(n=12)\end{array}$ & 26 & Sitagliptin & Yes & $\begin{array}{c}= \\
(\mathrm{NAS})\end{array}$ & $\begin{array}{c}= \\
(\mathrm{MRI})\end{array}$ & $\begin{array}{c}= \\
(\mathrm{MRI})\end{array}$ & $=$ & $=$ & $\downarrow$ \\
\hline $\begin{array}{l}\text { Petit et al. } \\
\text { (2017) [157] }\end{array}$ & $\mathrm{T} 2 \mathrm{D}(n=68)$ & 26 & Liraglutide & No & - & $\begin{array}{c}\downarrow \\
\text { (MRS) }\end{array}$ & - & $\downarrow$ & $\downarrow$ & $\downarrow$ \\
\hline $\begin{array}{l}\text { Feng et al. } \\
\text { (2017) [158] }\end{array}$ & $\begin{array}{l}\text { T2D and NAFLD } \\
\quad(n=87)\end{array}$ & 24 & $\begin{array}{l}\text { Liraglutide, } \\
\text { Metformin or } \\
\text { Gliclazide }\end{array}$ & No & - & $\stackrel{\downarrow}{\downarrow}$ & - & $\downarrow$ & $\downarrow$ & $\downarrow$ \\
\hline $\begin{array}{l}\text { Khoo et al. } \\
\text { (2017) [159] }\end{array}$ & $\begin{array}{c}\text { Obese NAFLD }(n \\
=24)\end{array}$ & 26 & $\begin{array}{l}\text { Liraglutide versus } \\
\text { Lifestyle }\end{array}$ & No & - & $\begin{array}{c}\downarrow \\
(\mathrm{MRI})\end{array}$ & - & $\downarrow$ & $\downarrow$ & - \\
\hline $\begin{array}{l}\text { Seko et al. } \\
\text { (2017) [107] }\end{array}$ & $\begin{array}{c}\text { T2D and } \\
\text { biopsy-proven } \\
\text { NAFLD }(n=15)\end{array}$ & 12 & Dulaglutide & Yes & $\downarrow$ & $\downarrow$ & - & $\downarrow$ & $\downarrow$ & $\downarrow$ \\
\hline $\begin{array}{l}\text { Cusi et al. } \\
\text { (2018) [106] }\end{array}$ & $\mathrm{T} 2 \mathrm{D}(n=971)$ & 26 & Dulaglutide & No & - & - & - & $\downarrow$ & - & $\downarrow$ \\
\hline $\begin{array}{c}\text { Yan et al. (2019) } \\
\text { [143] }\end{array}$ & $\begin{array}{l}\text { T2D and NAFLD } \\
(n=18)\end{array}$ & 26 & $\begin{array}{l}\text { Liraglutide }+ \\
\text { Metformin }\end{array}$ & No & - & $\begin{array}{c}\downarrow \\
\text { (MRI) }\end{array}$ & $\begin{array}{c}\downarrow \\
(\mathrm{MRI})\end{array}$ & - & $\downarrow$ & $\downarrow$ \\
\hline $\begin{array}{l}\text { Gastaldelli et } \\
\text { al. (2019) [111] }\end{array}$ & $\mathrm{T} 2 \mathrm{D}(n=228)$ & $28 / 52$ & $\begin{array}{c}\text { Exenatide }+ \\
\text { Dapagliflozin }\end{array}$ & No & - & - & - & $\downarrow$ & - & $\downarrow$ \\
\hline \multicolumn{11}{|c|}{$\begin{array}{l}\text { Abbreviations: ALT, alanine aminotransferase; APRI, AST to platelet ratio index; BMI, body mass index; CT, } \\
\text { computed tomography; FIB-4, fibrosis- } 4 \text { index; HbA1c, glycosylated hemoglobin; MRE, magnetic resonance } \\
\text { elastography; MRI, magnetic resonance imaging; MRS, magnetic resonance spectroscopy; NAFLD, non-alcoholic } \\
\text { fatty liver disease; NAS, NAFLD Activity Score; NASH, Non-alcoholic steatohepatitis; NFS, NAFLD fibrosis score; } \\
\text { T2D, type-2 diabetes; US, ultrasound. } \downarrow \text { represent a decrease; = represent no change. }{ }^{*} 24 \text { weeks lifestyle intervention, } \\
\text { followed by } 24 \text { weeks with liraglutide. } 10 \text { subjects continued liraglutide until } 96 \text { weeks and were followed up with }\end{array}$} \\
\hline
\end{tabular}

The effect of GLP-1RA on hepatic steatosis was observed in several mice models (including leptin-deficient ob/ob mice, leptin receptor-deficient $\mathrm{db} / \mathrm{db}$ mice, and high-fat diet (HFD) fed mice that showed a decrease after exenatide treatment [160-162] or liraglutide [163].

Liraglutide treatment reduced ALT in a dose-dependent matter (although the difference was significant only at the maximum dose, i.e., at $1.8 \mathrm{mg}$ ) [34,164]. Post-hoc analyses on the effects of other GLP-1RA on liver enzymes showed a reduction in liver enzymes with lixisenatide [113] and exenatide $[110,144,153]$. Among the long-acting GLP-1RA, both dulaglutide $[106,107]$ and semaglutide treatments were associated with improvement in ALT more evident in subjects with elevated ALT before treatment and in a dose-dependent way. Liraglutide promoted weight loss and beneficially altered the fat distribution by decreasing waist circumference, waist/hip ratio, and the amount of subcutaneous and visceral fat content and liver steatosis [145,150,152,155]. An ancillary study of the LEAD-2 (Liraglutide Effect and Action in Diabetes) trial analyzed the changes in liver, visceral and subcutaneous fat by computed tomography as liver-to-spleen attenuation ratio in 131 subjects treated with various doses of liraglutide+metformin versus placebo or glimepiride [145]. Liraglutide decreased liver fat only in the $1.8 \mathrm{mg} /$ day+metformin group while changes in 0.6 and $1.2 \mathrm{mg} /$ day liraglutide, placebo+metformin or glimepiride+metformin were not significantly different from baseline [145]. The LEAN (Liraglutide Efficacy and Action in Non-Alcoholic Steatohepatitis) trial is the largest trial 
so far that evaluates the efficacy of a GLP-1RA (i.e., liraglutide) in biopsy-proven NASH patients. Fifty-two patients were randomly assigned 1:1 to subcutaneous injections of liraglutide (1.8 $\mathrm{mg}$ daily) or placebo for 48 weeks [103]. Liraglutide induced resolution of NASH in 39\% of patients versus $9 \%$ of placebo.

Treatment with exenatide reduced liver steatosis $[109,146,150]$ and when added to pioglitazone, an oral hypoglycemic and insulin sensitizing drug approved for the treatment of T2D that acts on nuclear peroxisome proliferator activated receptor-gamma (PPAR- $\gamma$ ) [147], potentiated the known action of pioglitazone in reducing hepatic fat [92]. Similar effects were observed in the Duration-8 trial where exenatide alone or in combination with SGLT2 inhibitor dapagliflozin significantly reduced the liver fat scores [111].

Studies in animal models indicate that GLP-1RA treatment might be beneficial also for liver fibrosis. However, conclusive data on the effects of GLP-1RA on hepatic fibrosis and parameters of liver disease in humans are lacking (Table 2). In the LEAN trial fewer patients in the liraglutide group (2/23) showed progression in fibrosis compared to the placebo group (8/22), and a greater proportion of liraglutide-treated patients improved steatosis and hepatocyte ballooning, while no differences were seen in lobular inflammation and overall NAFLD activity score [103]. Trevaskis et al. showed that liraglutide treatment reduced immunostaining for type I collagen, the most abundant type in hepatic fibrosis [165]. In a retrospective study, liraglutide and pioglitazone, but not sitagliptin, decreased liver fibrosis index APRI (calculated as the aspartate aminotransferase (AST) to platelet count ratio), and the improvement was associated with weight loss and a marked reduction in AST and ALT levels [149]. An open-labeled, prospective study examined the effect of exenatide in eight T2D patients with biopsy-proven NAFLD [146]. After 28 weeks, liver histology assessed using the NAFLD Activity Score improved in three of eight subjects and fibrosis was reduced in four of eight subjects [146]. However, the lack of a control group and the small number of subjects is a major limitation in this study. In the study by Eguchi, 10 patients that received over two-year treatment with liraglutide showed improved histology while only 1 subject worsened his condition [155].

The number of patients enrolled in studies with GLP-1RA was often limited, without a control group. However, the meta-analysis performed by Dong et al. that included six studies (three with liraglutide and three with exenatide, but only three with liver biopsy including the LEAN study) showed that treatment with GLP-1RA reduced, compared to placebo, the degree of NASH activity (in terms of steatosis, lobular inflammation and hepatocytes ballooning) and the stage of fibrosis [166].

\subsection{Effect of GLP-1 and GLP-1RA on Hepatic Glucose and Lipid Metabolism}

The liver has a crucial role in maintaining glucose homeostasis, which is tightly orchestrated by the action of pancreatic insulin and glucagon. Gut hormones, particularly incretins, are also involved in this regulation (Figure 2) not only through the potentiation of insulin secretion. Several studies have shown an improvement in hepatic glucose and lipid metabolism after GLP-1 injection $[167,168]$ or GLP-1RA treatment $[24,102,169-171]$ either in humans and animal studies.

The positive effect of GLP-1RA on diabetic hyperglycemia and hepatic metabolism appears to be due in part to weight loss through their effects on appetite and food consumption and in part to reduced glucotoxicity in T2D. However, infusion of native GLP-1 showed acute effects on glucose metabolism by reducing hepatic glucose production $[167,168]$.

GLP-1 receptor was found in nerves that innervate hepatocytes [172], but their presence on human liver or hepatocytes is debated as found by some [169,170] but not others $[173,174]$. A recent study that used incretins (GLP-1 and Exendin-4) radiolabeled with technetium-99m showed that the tracer was highly taken up both by the liver and the pancreas and that the uptake was reduced in both organs after diet-induced obesity (DIO), similarly to alloxan diabetes controls [175].

In addition to the glucose-lowering actions, GLP-1RA based therapies have been reported to improve both fasting and postprandial lipid profiles in patients with T2D, in particular triglyceride concentrations $[104,147,153,176,177]$. Native GLP-1 did not change free fatty acid (FFA) concentrations 
or glycerol rate of appearance [168]. On the other hand, peripheral lipolysis is often found reduced after GLP-1RA treatment $[102,178]$ possibly because of weight loss. However, it is now evident that GLP-1RA improves the antilipolytic effect of insulin by reducing adipocyte insulin resistance and the overflow of FFA to the liver [24,102].

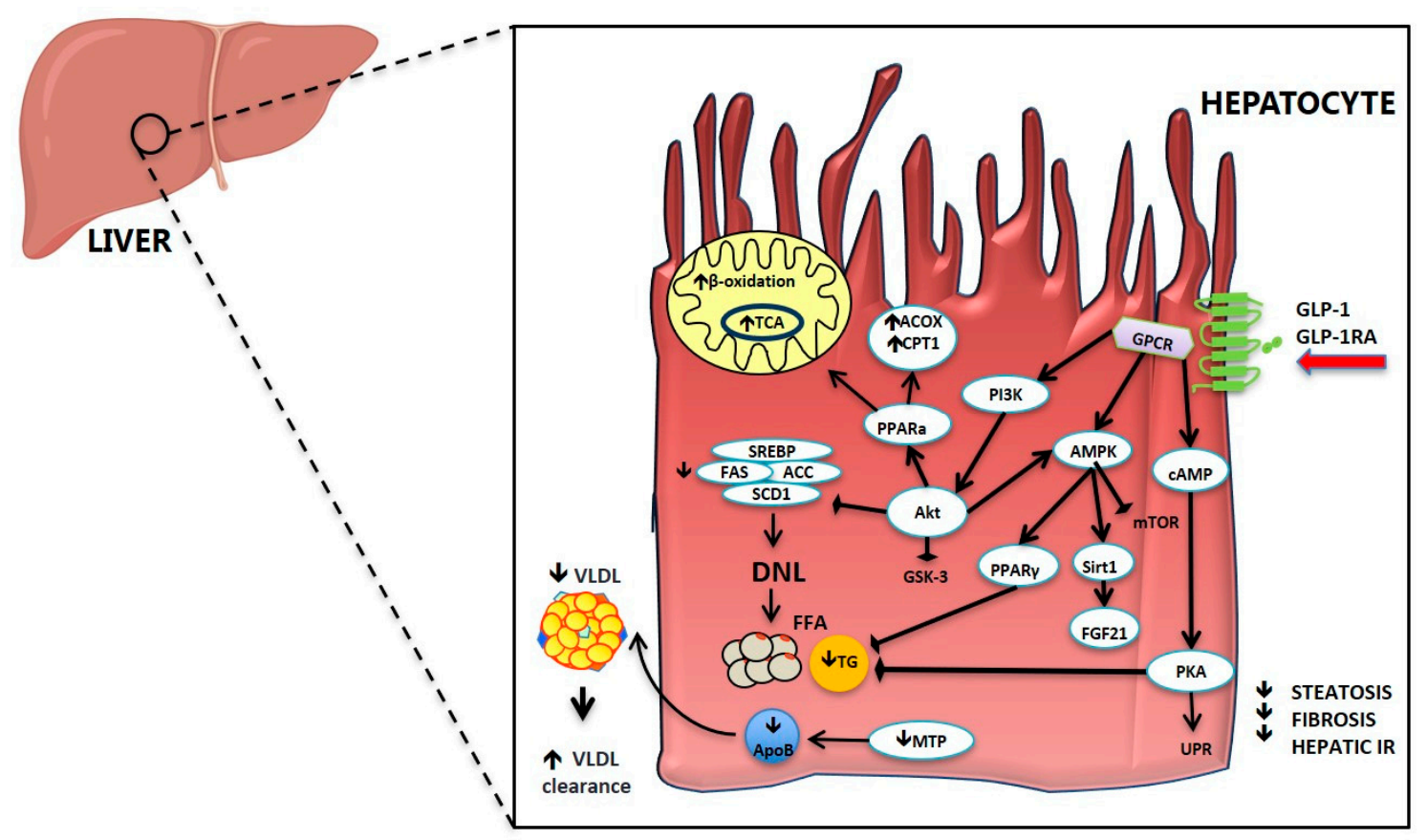

Figure 2. Mechanistic effects of GLP-1 and GLP-1 receptor agonists in hepatic lipid metabolism. GLP-1 and GLP-1 receptor agonists act via G protein-coupled receptors (GPCRs) in hepatocytes to target several signaling pathways, resulting in increased $\beta$-oxidation in mitochondria, decreased hepatic mRNA expression of several lipogenic genes (SREBP1, FAS, ACC and SCD1), reduced de novo lipogenesis (DNL) and reduced steatosis. Abbreviations: ACC, Acetyl-CoA carboxylase $\alpha$; ACOX, Peroxisomal acyl-coenzyme A oxidase; Akt, Serine/threonine protein kinase B/Akt; AMPK, 5' AMP-activated protein kinase; ApoB, Apolipoprotein B 100; cAMP, Cyclic adenosine monophosphate; CPT1, Carnitine palmitoyltransferase 1; DNL, de novo lipogenesis; FAS, Fatty acid synthase; FFA, Free fatty acids; FGF21, Fibroblast growth factor 21; GLP-1, Glucagon-like peptide-1; GLP-1RA, Glucagon-like peptide-1 receptor agonists; GPCR, G-protein-coupled receptors; GSK-3, Glycogen synthase kinase 3; MTP, Microsomal triglyceride transfer protein; mTOR, mammalian target of rapamycin; PI3K, Phosphoinositide 3-kinase; PKA, Protein kinase A; PPAR, Peroxisome proliferator-activated receptor; SCD1, Stearoyl-CoA desaturase 1; Sirt1, Sirtuin 1; SREBP, Sterol regulatory element-binding protein; TCA, Tricarboxylic acid cycle; TG, Triglyceride; UPR, Unfolded protein response; VLDL, Very-low-density lipoprotein.

The mechanism(s) through which gut hormones regulate hepatic lipid metabolism are still unclear. In Figure 2 we have summarized some of the proposed mechanisms for GLP-1 and GLP-1RA. In vitro studies have demonstrated a direct effect of GLP-1 and GLP-1RA on hepatocyte fatty acid metabolism [102,170,179]. It has been proposed that GLP-1RA ameliorate hepatic steatosis by increasing fatty acid oxidation, enhancing very-low-density lipoprotein (VLDL) secretion and inhibiting lipogenesis [170,180]. Treatment of Huh7 and HepG2 hepatoma cells with exenatide decreased intracellular lipid accumulation [181,182] by enhancing fatty acid oxidation and reducing lipogenesis $[160,161,179,183]$. In hepatocytes from rats that developed NASH after HFD, exenatide activated genes involved in hepatic fatty acid $\beta$-oxidation and insulin sensitivity such as PPAR- $\gamma$ expression, protein kinase A activity, serine/threonine protein kinase B/Akt and AMP-activated protein kinase (AMPK) phosphorylation, and PPAR- $\alpha$ activity, that were altered by HFD treatment [170] (Figure 2). GLP-1-treated hepatocytes manifested a significant increase in cAMP production and a 
reduction in mRNA expression of stearoyl-CoA desaturase 1 and genes associated with fatty acid synthesis, such as acetyl-CoA carboxylase and fatty acid synthase $[160,184]$. The converse was true for genes associated with fatty acid oxidation [160].

GLP-1RA treatment has been associated with alterations in lipid and lipoprotein metabolism in patients with T2D. Administration of a single subcutaneous injection of exenatide $(10 \mu \mathrm{g})$ prior to a meal was shown to reduce postprandial TG, apolipoproteins B-48 and CIII, remnant lipoprotein (RLP)-cholesterol and RLP-TG in comparison to saline injection [185]. Other studies reported similar results with liraglutide once-daily for three weeks [186] and 16 weeks [104]. Whyte et al. showed that a four-week treatment with lixisenatide reduced chylomicron $(\mathrm{CM})$-TG pool-size and $\left[{ }^{13} \mathrm{C}\right]$ oleate concentrations, and increased CM-TG clearance without affecting CM-TG production rate. These data lead the authors to conclude that the decreased CM-TG concentration may result from increased clearance rather than decreased production of lipoproteins [187]. Additionally, a four-week treatment with DPP-4 inhibitor vildagliptin was also found to induce reductions in the postprandial TG and apolipoprotein B-48 containing TG-rich lipoprotein particle metabolism after a fat meal [177].

\subsection{Impact of DPP-4 and Its Inhibition on NAFLD}

The dipeptidyl peptidase-4 (DPP-4), also known as CD26, is a ubiquitously expressed protease that degrades several substrates, such as incretin hormones and thereby is a therapeutic target in diabetes treatment. DPP-4 is highly expressed in liver and DPP-4 mRNA expression is increased in the liver of patients with NAFLD, compared to healthy subjects [188]. Moreover, serum DPP-4 activity and hepatic staining of DPP-4 are correlated with NASH grade but do not correlate with the fasting blood glucose concentration or glycosylated hemoglobin $(\mathrm{HbA1c})[189,190]$. These observations suggest that hepatic DPP-4 expression in NAFLD might be directly associated with hepatic lipogenesis and liver injury but not with alteration in glucose metabolism.

Few data are available with DPP-4 inhibitors and NAFLD/NASH (Table 2). Studies in mice reported a reduction in liver TG and histologic grade of hepatic steatosis with sitagliptin [183] but if this is a direct or indirect effect is uncertain. DPP-4 deficient rats have three-fold higher basal GLP-1 levels and significantly reduced serum and hepatic TG level compared with controls [179]. Patients with NASH have increased serum DPP-4 activity compared to controls and also increased hepatic staining of DPP-4 that correlated with hepatic steatosis and histopathological grade of NASH but were not correlated to each other [190]. In a small cohort of T2D patients with NASH, one-year treatment with the DPP-4 inhibitor sitagliptin decreased hepatocyte ballooning and improved NASH score [148]. The improvement in hepatic histology was correlated to the reduction in BMI and serum AST and ALT levels. However, the reduction in steatosis score was of borderline statistical significance and no change was observed in either liver fibrosis or lobular inflammation $[115,148]$ (Table 2). The available data suggest that treatment with DPP-4 inhibitors may have a mild beneficial effect on NAFLD, probably mediated by the increase in GLP-1 concentrations after blocking DPP-4 activity.

It is important to note that DPP-4, also known as CD26, can also derive from the gut, due to the microbiota DPP-4-like activity [191]. Recently, reduction of DPP-4 activity by vildagliptin was linked with the prevention of gut permeability disruption in mice subjected to western diet [191]. Moreover, Olivares et al. suggested that this effect is in part due to the vildagliptin properties on the microbiota-derived DPP-4. Even though DPP-4/CD26 is expressed at high levels in the intestine, specifically in the jejunum and ileum, its role in promoting gut permeability is still unclear [192].

\subsection{GLP-1 Co-Agonists in the Treatment of Lipid Disorders and NAFLD/NASH}

Several drugs that combine GLP-1RA and other hormones-e.g., combined double co-agonism of GLP-1 receptors and glucagon, an analogue of oxyntomodulin, combination GLP-1/GIP or triple co-agonism of the of GLP-1/GIP/glucagon receptors-are in the pipeline for the treatment of T2D and obesity, and have been studied in the context of NAFLD/NASH [193-195] (Tables 1 and 3). GIP targets the white adipose tissue (Figure 1) improving its buffering capacity by promoting postprandial 
triglyceride storage and fatty acids re-esterification [196]. Glucagon has also effects on lipid metabolism stimulates lipolysis and hepatic fatty acid oxidation [197] but its effects should be always be considered relative to the insulin levels since insulin exerts opposite effects on lipid metabolism [198].

Table 3. Current GLP-1, GIP, and glucagon receptor co-agonists in development for treatment of T2D/obesity.

\begin{tabular}{|c|c|c|c|c|}
\hline Co-agonism & Drug & Company & $\begin{array}{c}\text { Stage of } \\
\text { Development }\end{array}$ & References \\
\hline \multirow[t]{9}{*}{ GLP-1/glucagon } & Cotadutide (MEDI0382) & Medimmune & Phase II & {$[64,65]$} \\
\hline & HM12525A; JNJ-64565111 & Hanmi Pharmaceuticals & Phase II & [67] \\
\hline & MK- 8521 & Merck & Phase II & [67] \\
\hline & SAR425899 & Sanofi & Phase II & [199] \\
\hline & ZP2929; BI 456906 & Zealand Pharma & Phase II & {$[66,67]$} \\
\hline & JNJ-54728518 & Janssen Pharmaceuticals & Phase I & {$[200]$} \\
\hline & NN9277; NNC 9204-1177 & Novo Nordisk & Phase I & - \\
\hline & MOD-6030 & Prolor/OPKO Biologics & Phase I & [201] \\
\hline & VPD-107 & Spitfire Pharma & Pre-clinical & - \\
\hline \multirow[t]{5}{*}{ GLP-1/GIP } & Tirzepatide (LY3298176) & Eli Lilly & Phase III & [84-86] \\
\hline & $\begin{array}{c}\text { NNC0090-2746; NN970 9; } \\
\text { MAR709; RG7697 }\end{array}$ & Novo Nordisk/Marcadia & Phase III-stopped & [87] \\
\hline & CPD86 & Eli Lilly & Pre-clinical & - \\
\hline & ZP-I-98 & Zealand Pharma & Pre-clinical & - \\
\hline & ZP-DI-70 & Zealand Pharma & Pre-clinical & - \\
\hline \multirow[t]{2}{*}{ GLP-1/GIP/glucagon } & HM15211 & Hanmi Pharmaceuticals & Phase I & [40-42] \\
\hline & $\begin{array}{l}\text { NN9423; NNC 92041706; } \\
\text { Tri-agonist } 1706\end{array}$ & Novo Nordisk & Phase I & [67] \\
\hline
\end{tabular}

Abbreviations: GIP, Glucose-dependent insulinotropic peptide; GLP-1, Glucagon-like peptide-1; GLP-1RA, Glucagon-like peptide-1 receptor agonists; NA, Not available; LFT, Liver function tests; DPP-4, Dipeptidyl peptidase-4; PO, Oral administration; SC, Subcutaneous administration.

Once per week administration of a dual GLP-1/glucagon co-agonist attached to polyethylene glycol (PEG), a process called PEGylation, improved glucose tolerance, reduced body weight and body fat by decreasing food intake and increasing energy expenditure, while normalizing liver lipid content, within a four-week treatment in DIO mice [202]. Day et al. further optimized the co-agonism to equally align activity at each receptor, which maximized weight-loss and glucose-lowering effects [203]. Another study in DIO mice injected with a protease-resistant dual GLP-1/glucagon co-agonist showed similar results in terms of weight loss, lipid-lowering activity, anti-hyperglycemic efficacy, increased fatty acid oxidation and reduced hepatic steatosis [204]. In methionine/choline-deficient diet-fed mice, two-week treatment with a dual GLP-1/glucagon co-agonist (G49) ameliorated NASH by reducing inflammation, steatosis, oxidative stress, and apoptosis and increased mitochondrial biogenesis [205]. Interestingly, PEGylated dual GLP-1/glucagon co-agonism was also shown to restore leptin sensitivity in DIO mice continuously exposed to HFD, and the combination with PEGylated leptin resulted in a greater weight loss and improvement in lipid and glucose metabolism when compared with PEGylated GLP-1/glucagon alone [206]. In HFD-induced NAFLD mice, treatment with a dual GLP-1/glucagon co-agonist for 40 weeks prevented body weight gain, glucose intolerance and insulin resistance, while it decreased circulating and hepatic lipid content. Histological assessment of these animals showed a reduced fat accumulation, inflammation and fibrosis in co-agonist treated animals [207]. In comparison with liraglutide alone, MEDI0382, a dual GLP-1/glucagon co-agonist achieved greater weight loss and comparable glucose-lowering actions in DIO mice and non-human primates [208]. In patients with

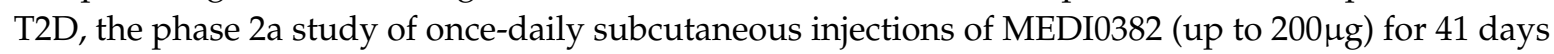
significantly decreased glucose area under the curve after four hours of a mixed-meal tolerance test, and body weight in comparison with placebo [64]. In another trial, SAR425899, a dual GLP-1/glucagon co-agonist, significantly reduced fasting plasma glucose, $\mathrm{HbA1c}$, and body weight in patients with T2D as well as in healthy volunteers when compared to placebo [199]. 
Another class of drugs are the dual GIP/GLP-1 co-agonists (Tables 1 and 3). Once-weekly administration of tirzepatide (LY3298176), a dual GIP/GLP-1 co-agonist, for 26 weeks significantly reduced $\mathrm{HbA1c}$ and body weight in a dose-dependent way, and at the highest dose $(15 \mathrm{mg})$ reduced total cholesterol and TG concentrations in comparison both with placebo and dulaglutide $1.5 \mathrm{mg}$ in patients with T2D [84]. More recently, Hartman et al. found that once-weekly administration of tirzepatide for 26 weeks significantly reduced biomarkers of NASH and fibrosis (ALT, AST, keratin-18, and procollagen-C3) and increased adiponectin compared with placebo at a higher tirzepatide dose (15 mg) in patients with T2D [85].

The fatty-acylated dual GLP-1/GIP co-agonist NNC0090-2746, also known as NN9709, MAR709, and RG7697, significantly improved glycemic control and reduced body weight and total cholesterol compared with placebo after a 12-week phase 2 trial [87]. Similarly, treatment with RG7697 for 14 days yielded a reduction in fasting and postprandial plasma glucose in a dose-dependent way in patients with T2D in comparison with placebo, as well as a decrease in postprandial insulin, suggesting an improvement in insulin sensitivity [209].

A triple agonist of GLP-1, GIP and glucagon receptors (Tables 1 and 3) was found to have better results in terms of reduction of body weight, improvement in glycemic control and reversion of hepatic steatosis in rodents in comparison with existing dual co-agonists and best-in-class mono-agonists [210]. The authors showed that the metabolic efficacy of the triple agonist results from the synergistic action of glucagon to increase energy expenditure, GLP-1 to reduce food intake and improve glucose homeostasis, and GIP to potentiate incretin role and protect against the glucagon diabetogenic effect [210]. In body fat mass matched male and female mice, treatment with GLP-1/GIP/glucagon triple agonism inhibited food intake, improved dyslipidemia, and decreased body weight and body fat mass in both groups, and reversed diet-induced steatohepatitis to a larger extent in female mice compared to male mice [211]. Therefore, development of therapies based on dual and triple co-agonists of GLP-1, GIP and glucagon receptors might be of interest (Table 3), not only for T2D or obesity but also for NAFLD/NASH; however, more studies are needed.

\section{Gut Microbiota Dysbiosis and the Gut-Liver Axis in NAFLD}

The intestine is anatomically wired to the liver and brain through blood circulation and systemic innervation. In this perspective, intestinal dysfunction has been investigated as a determinant of hepatic impairment. A large body of evidence collected in recent years supports the novel concept that the gut-liver axis wires physiological mechanisms of inter-organ control affected in many metabolic diseases. The gut is colonized by a wide range of microorganisms, including bacteria that co-evolved with the host in a symbiotic relationship - the gut microbiota. The gut microbiota includes a diverse range of symbiotic bacteria and other microorganisms that colonize the human intestine [212]. These bacteria produce a large array of metabolites that serve as important signaling factors and energy substrates, such as bile acids (BA), choline, neurotransmitters, and short-chain fatty acids (SCFA) [213]. The crosstalk between these metabolites and the host modulates the immune system, regulates metabolic phenotypes, and influences risk factors for disease and response to therapy (Figure 3). The gut microbiota composition differs along the intestinal tract depending on physiological conditions, such as gastrointestinal content flow rates, availability of substrates for microorganisms, lumen $\mathrm{pH}$, oxygen availability and immunological features [214]. For example, a large number of species and diversity are lowered in the small intestine compared to the colon, since the small intestine is characterized by adverse conditions for bacterial growth, such as low $\mathrm{pH}$, antimicrobials response and short transit time; in this tract, the most abundant species are Lactobacillaceae and Enterobacteriaceae [215]. At the phylum level, gut microbiota composition is dominated by Firmicutes and Bacteroidetes, followed by Proteobacteria and Verrucomicrobia [216]. 


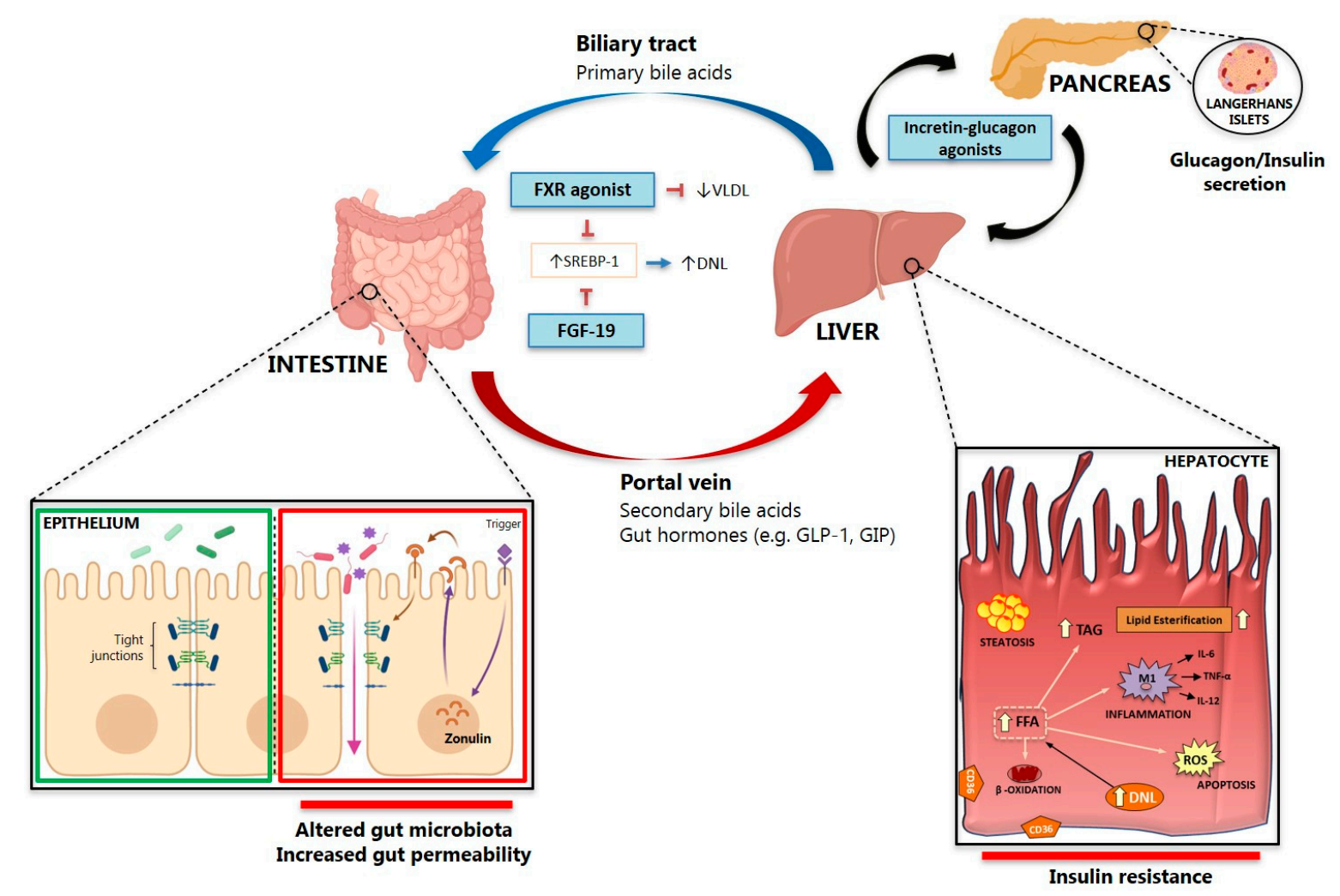

Figure 3. The gut-pancreas-liver axis in the context of non-alcoholic fatty liver disease (NAFLD). The intestine and the liver are in constant communication through the portal vein and the biliary tract. In the intestine, the maintenance of the intestinal endothelial cell barrier achieved through tight junctions is crucial. In pathological conditions, an alteration in the diversity and composition of gut microbiota could lead to the secretion of harmful bacterial products, which consequently damages the intestinal epithelium by disrupting tight junctions. Another mechanism that has been indicated to explain increased intestinal permeability is zonulin, a protein secreted within intestinal cells upon a trigger (e.g., gluten), which is thought to be responsible for tight junction disassembling. In such conditions, harmful bacteria/bacterial products cross the intestinal wall and reach the liver via portal circulation, where they activate toll-like receptors (TLRs) on hepatocyte cell surface, promoting steatosis, inflammation, apoptosis, and insulin resistance. The intestine is also responsible for the secretion of the incretin hormones GLP-1 and GIP upon nutrient stimulation, which go through the liver, reach circulation, and target the pancreas to regulate insulin and glucagon secretion. On the other hand, the liver secretes primary bile acids into the intestine to aid digestion, which are converted into secondary bile acids by gut microbiota, and the majority are reabsorbed back to the liver. A rearrangement in the gut-pancreas-liver axis has been hypothesized to play a role in the pathogenesis and development of NAFLD. Abbreviations: CD36, Cluster of differentiation 36; DNL, de novo lipogenesis; FFA, Free fatty acids; GIP, Glucose-dependent insulinotropic peptide; GLP-1, Glucagon-like peptide-1; IL, Interleukin; ROS, Reactive oxygen species; TAG, Triglycerides; TNF- $\alpha$, Tumor necrosis factor $\alpha$.

"Normal" gut flora maintains a symbiotic relationship with the host, which confers benefits to both species in terms of immune system development and efficiency and energy metabolism regulation [217]. However, when qualitative and quantitative modifications of the gut microbiota occur, i.e., dysbiosis, the development of chronic diseases, including obesity, diabetes and NAFLD is promoted [218]. The association between dysbiosis and these metabolic conditions was firstly suggested by Turnbaugh et al. [219] where the authors showed that transferring gut microbiota from obese to lean rodents induced in the recipient the same metabolic alterations observed in the donor.

From then, it has been shown that dysbiosis can influence the occurrence of progression of NAFLD through several mechanisms. The gut microbiomes of patients with advanced liver disease 
and cirrhosis are characterized by an increase in potentially pathogenic bacteria, along with reduced numbers of bacteria with beneficial properties [220-225]. Mouzaki et al. found that patients with NASH have a lower fecal percentage of Bacteroidetes compared to both patients with simple hepatic steatosis and healthy controls [224]. Zhu et al. have found in pediatric patients that Proteobacteria, Enterobacteriaceae, and Escherichia were the only phylum, family and genus types exhibiting a significant difference between obese and NASH microbiomes. They also found that Proteobacteria produced significant ethanol levels that could be responsible for the higher degree of liver injury [225].

In NAFLD models, lack of inflammasomes has been demonstrated to select a pathogenetic microbiota which was associated with a more severe degree of liver injury [226]. In addition, it has been recently shown that a Western lifestyle diet associated with lack of NLRP3-inflammasome, increased fat storage in adipose tissue and liver leading to a more severe liver injury. This effect was associated with the expansion of Gram-negative Proteobacteria and Verrucomicrobia [227], the main pathobionts responsible of liver injury in a model of HFD and fibrosis [228], and together with Verrucomicrobia are known to be mucus-degrading bacteria, favoring bacterial translocation. In patients with hepatocellular carcinoma (HCC), Bacteroides and Ruminococcaceae were increased, while Bifidobacterium was reduced, and Akkermansia and Bifidobacterium were inversely correlated with calprotectin, a marker of intestinal inflammation that was increased in HCC patients [229].

In addition to its role in modulating the progression of chronic liver disease, differences in microbiota composition have been attempted to stratify NAFLD patients by degree of liver injury. Boursier et al. found that NAFLD severity was associated with gut dysbiosis and a shift in the metabolic function of the gut microbiota with Bacteroides independently associated with the occurrence of NASH, and Ruminococcus with the presence of significant fibrosis [230]. Del Chierico et al. [231] showed that either in obese or in NAFLD/NASH pediatric patients, microbiota diversity was reduced from controls to obese, NAFLD and NASH patients, and the combination of specific microbiota and metabolite modifications was able to discriminate control patients from those with NAFLD or NASH [231]. Similarly, Loomba et al. constructed a metagenomic-based model to distinguish advanced fibrosis in adult patients with NASH based on increased Proteobacteria (mostly E. Coli) levels and a decrease in Firmicutes [232]. Studies performed in cohorts of morbidly obese women confirmed the increased in Gram- proteobacteria and linked, for the first time, steatosis occurrence with alterations in aromatic and branched-chain amino acid metabolism [233].

\section{Alterations of Lipid and Glucose Metabolism by Gut Bacteria}

Bacterial biodiversity has been associated with a most favorable metabolic profile, but bacterial products can, directly and indirectly, influence glucose and lipid metabolism. Changes in synthesis and production of SCFA by colonic bacterial fermentation of polysaccharides (such as acetate, propionate, and butyrate) are the most studied mechanisms relating the association between gut microbiota and development/progression of NAFLD. A close correlation between SCFA and NAFLD development have been demonstrated both in experimental models of NAFLD and obese patients that have increased concentration of stool SCFA [219,234]. SCFA can bind specifically to GPCRs such as GPR41 and GPR43, which are expressed in the adipose tissue, liver, and intestine and induce metabolic modifications influencing de novo lipogenesis, cholesterol synthesis and glucose homeostasis [235]. Increased acetate in the liver can cause TG accumulation as acetate is an important substrate for fatty acid synthesis, while increased levels of propionate promote gluconeogenesis in the liver since propionate is a precursor for gluconeogenesis [236].

Moreover, SCFA can stimulate the release of GLP-1 in vitro and in vivo dependently of the FFA receptor 2 (Figure 1) [237]. Furthermore, SCFA can modulate food intake by regulating neuronal activity and thus appetite regulation [219]. Although SCFA directly or via binding to G-protein-coupled receptors (GPCR) appear to promote NAFLD, other effects of SCFA might be beneficial for NAFLD mostly by modulating AMPK activity in the liver [236]. Furthermore, butyrate has been demonstrated to influence colonic epithelium regeneration, thus providing an important mechanism in the regulation 
of gut integrity [238]. Propionate can also bind to GPCR-43 expressed on lymphocytes to maintain appropriate immune defense. Butyrate activates PPAR- $\gamma$ leading to beta-oxidation and oxygen consumption, a phenomenon contributing to maintaining anaerobic condition in the gut lumen [239].

A second mechanism relates to the direct effect on lipid metabolism. One of the most known effects is the capacity of intestinal bacteria to inhibit the synthesis of fasting-induced adipocyte factor (also known as angiopoietin-related protein 4), a specific inhibitor of the lipoprotein lipase. Lack of inhibition of lipoprotein lipase leads to a stronger release (spillover) of FFA from VLDL particles to the liver, favoring the development of steatosis [240]. Finally, the host response to translocated microbial products predicts outcomes also in patients with hepatitis B and $C$ virus infections, indicating that bacterial translocation contributes to the progression of chronic liver injury not only in the presence of metabolic or alcoholic disease [241].

\section{Bile Acid Signaling in NAFLD}

One of the most intriguing aspects of the role of dysbiosis in the progression of chronic liver injury is related to the interactions between gut microbiota and bile acids (BA). In hepatocytes, BA are synthesized via cytochrome P450 (CYP)-mediated oxidation of cholesterol by two biosynthetic pathways: the "classical" and "alternative" pathways. The "classical" pathway produces the primary BA cholic acid and chenodeoxycholic acid through the enzymatic actions of cholesterol hydroxylase enzymes CYP7A1, CYP8B1, and CYP27A1. The "alternative" pathway yields chenodeoxycholic acid via the hydroxylation of the cholesterol sidechain by CYP27A1, followed by $7 \alpha$-hydroxylation of 27-hydroxycholesterol and other oxysterols by CYP7B1. Following the conjugation of cholic acid and chenodeoxycholic acid to either taurine or glycine to form taurocholic acid, glycocholic acid, taurochenodeoxycholic acid (TCDCA) and glycochenodeoxycholic acid (GCDCA), primary BA are secreted from the liver into the bile canaliculus via the canalicular bile salt export pump [242].

In the gut, gut bacteria metabolize BA, and glyco-conjugated and tauro-conjugated cholic and chenodeoxycholic acids are deconjugated via bile salt hydrolases and $7 \alpha$-dehydroxylated to form secondary BA deoxycholic acid (DCA) and lithocholic acid (LCA) [243]. The ability of the gut microbiota to metabolize intestinal BA into their unconjugated forms is central to metabolic homeostasis since these unconjugated BA can activate BA signaling receptors such as farnesoid $X$ receptor (FXR), pregnane $X$ receptor, constitutive androstane receptor, vitamin $D$ receptor and Takeda $G$ protein receptor 5 (TGR5) [242].

Normal intestinal FXR activity maintains an efflux of BA back into the portal vein and a controlled reuptake of BA into enterocytes. This limits intracellular BA levels and regulates the expression of fibroblast growth factor (FGF)-15 in mice and its orthologue FGF19 in humans, which inhibit BA synthesis in hepatocytes via the activation of hepatic FGF receptor 4 [243]. During intestinal inflammation, the expression of FXR is downregulated leading to an increased influx of BA into the enterocytes and reduced BA efflux back into the portal vein, with the net effect of higher BA levels in the intestinal mucosa. Thus, intestinal FXR downregulation diminishes signaling via the FGF19-FGF receptor 4 axis leading to (a) increased BA synthesis in the liver; (b) increased hepatic influx of BA; (c) detoxification and BA biliary secretion blockage. These series of events induce cholestasis followed by alterations in carbohydrate and lipid metabolisms, and induces inflammation, leading to the upregulation and activation of factor nuclear kappa B (NF- $\mathrm{kB}$ ), which then binds directly to the FXR promoter to inhibit its transcription [244]. An example of the complex interactions between diet, dysbiosis and BA comes from the observation that coupling an HFD with a chemical carcinogen to induce a shift to a Gram-positive microbiota was able to increase DCA levels, to induce a senescence-associated secretory phenotype in hepatic stellate cells that activated the inflammasome system, leading to increased HCC formation. This was confirmed with a non-selective antibiotic cocktail that induced tumor reduction and by the use of the antibiotic vancomycin that selectively acts on Gram-positive bacteria [245]. 
The secondary BA DCA is known to promote DNA damage and hepatic carcinoma and accumulates significantly on an animal product-based diet in humans [246]. Increased circulating DCA levels have been found in patients with NASH [247]. Neonatal mice mimicking all the histological spectrum of NAFLD that were treated with streptozocin to induce diabetes and HFD-fed showed increased lipopolysaccharide (LPS) levels both in the liver and in feces, increased hepatic BA levels, and down-regulation of the FXR/FGF15 axis. The progression of chronic liver injury was associated with a relationship between dysbiosis and specific BA formation (DCA, LCA, TCDCA, GCDCA) with an increase in specific bacteria genera (Clostridium, Bacteroides, E. Coli) and reduction in A. muciniphila that significantly correlated with specific increases in secondary BA $[248,249]$. These BA (DCA, TCDCA, GCDCA) are significantly increased in patients with NASH [247].

Targeting BA Receptors as a Therapeutic Option for NAFLD

FXR agonism has shown benefit in several preclinical models of NAFLD/NASH, inducing metabolic effects that reduce steatosis and inflammation (Figure 3) [250]. On the other hand, a direct effect of FXR agonism on hepatic fibrosis is controversial [251]. This has led to the design of clinical trials involving the FXR agonist obeticholic acid (OCA) in human patients (Table 1). In the first trial, Mudaliar et al. found improved insulin resistance and decreased liver fibrosis markers in diabetic patients with NAFLD treated with OCA [82]. Then, the FLINT trial (FXR Ligand Obeticholic Acid in NASH Treatment, NCT01265498) included NASH patients treated with OCA ( $25 \mathrm{mg} /$ day) for 72 weeks [83]. Although patients treated with OCA showed a significant improvement in the NAFLD activity score (i.e., the primary histological outcome) and a significant decrease in liver fibrosis, NASH resolution occurred in only $22 \%$ of patients treated with OCA (without a statically significant effect compared to placebo), and no effect was observed in patients with advanced fibrosis. Although OCA was generally well tolerated, concerns were raised by the occurrence of side effects such as pruritus, which developed in $23 \%$ of patients on OCA without leading to drug discontinuation, increased total serum cholesterol and low-density lipoprotein (LDL)-cholesterol levels and a modest, but significant, reduction in high-density lipoprotein (HDL)-cholesterol [83]. More recently, the interim analysis at month 18 of the phase 3 trial REGENERATE showed that $23 \%$ and $18 \%$ of the subjects in the $25 \mathrm{mg}$ and $10 \mathrm{mg}$ group respectively vs $12 \%$ in the placebo group met the primary endpoint, i.e., fibrosis improvement by at least one stage with no worsening of NASH with a similar adverse event and safety profile compared to the phase 2 trial [81]. However, these results were not sufficient to receive FAD accelerated approval for the treatment of patients with liver fibrosis due to NASH [252].

The side effect on cholesterol levels might be important when considering that patients with NAFLD/NASH have an increased risk of cardiovascular diseases and high cholesterol is a major risk factor for atherosclerosis. Thus, further studies are needed to better define the clinical usefulness of FXR agonism in NASH. Firstly, the site of FXR agonism can be of critical importance. Moreover, while mice with whole-body FXR deficiency spontaneously develop liver tumors [253], De Girolamo et al. showed that no tumor formation was observed in mice expressing FXR only at the intestine level [254]. The gut-restricted FXR agonist fexaramine robustly induces enteric FGF15, leading to alterations in BA composition, without activating FXR target genes in the liver and reducing diet-induced weight gain, body-wide inflammation, hepatic glucose production, while enhancing thermogenesis and browning of white adipose tissue [255]. Conversely, some data also indicate that antagonism of intestinal FXR signaling could improve metabolic parameters in murine models of NAFLD $[256,257]$. The underlying mechanisms are still unclear but may be related to the existence of an "intestinal FXR/ceramide axis" whereby ileal production of ceramides, mediated by BA modification by the microbiota, controls the hepatic lipogenic pathway via sterol regulatory element-binding protein 1c (SRBEP1c).

Finally, concerns can be raised regarding the chronically increased levels of FGF19 resulting from FXR agonism. FGF19 has the potential to regulate several pathways involved in NASH pathogenesis since it can act on CYP7A1, the rate limiting enzyme in BA synthesis from cholesterol, in addition to mimicking the effect of insulin on glycogen synthesis and gluconeogenesis [258]. However, 
the therapeutic potential of FGF19 has been hindered by its effect on potential occurrence of HCC, since mice expressing an FGF19 transgene developed liver tumors while tumor FGF19 hepatic mRNA expression was an independent prognostic factor for overall and disease-free survival $[259,260]$. It has been found that the tumorigenic effect of FGF19 is mediated by the release of interleukin 6 (IL6) by Kupffer cells that activate the signal transducer and activator of transcription (STAT3) pathway in hepatocytes [261]. On the other hand, an engineered FGF19 analogue (NGM82) has shown efficacy in animal models of NASH. Furthermore, NGM282 can block hepatocarcinogenesis associated with human FGF19. In animal models of NASH, treatment with NGM282 resulted in the reduction of ALT and AST, as well as improvement in all histological features associated with NASH-hepatic steatosis, inflammation, ballooning degeneration, and fibrosis - thus leading to test NGM282 in clinical trials [262-264] (Table 1). In the first clinical trial, NGM282 showed significant reductions in liver fat content, as measured by magnetic resonance imaging proton density fat fraction, with an acceptable safety profile in patients with NASH [59]. Following this, in a recent open-label study, NGM282 improved the histological features of NASH with significant reductions in NAS and fibrosis scores, accompanied by improvements in noninvasive imaging and serum markers, although this effect was observed after only 12 weeks of treatment [60].

\section{Gut Permeability}

The term intestinal permeability refers to the intestinal epithelium as a barrier that physiologically controls the exchange of ions, water and macromolecules between the luminal content and the underlying tissues, and that is protected from direct contact with bacteria, food allergens, toxins, and excreted metabolic byproducts by a mucus layer. The apical surface of the epithelium is a continuum of single cells whose paracellular space is sealed by a series of intercellular junctions, of which tight junctions (TJ) (Figure 3). One type of TJ is involved in the high-capacity pore pathway to transport ions and small molecules, and the other type is involved in the leak pathway, modulating the flux of large macromolecules [265]. Proteins of the TJ such as claudins play a relevant role in the high capacity pore pathway, whereas zonula occludens-1 (ZO-1 or Tjp1), occludin, and tricellulin (also known as Marveld2) control the low-capacity leak pathway [265].

Zonulin, the only physiological modulator of tight junctions described to date, was discovered as the precursor of haptoglobin-2 (pre-Hp2) [266] and is essential for the regulation of intestinal permeability [267-269] (Figure 3). Zonulin is the only measurable blood protein that reflects intestinal permeability, and increased zonulin levels are considered to be a marker of impaired intestinal barrier [269]. The epithelial barrier dysfunction may be triggered by the presence of some microbial communities and their derived metabolites $[270,271]$, which can be assessed by circulating zonulin as well as by circulating LPS. Additionally, intestinal permeability can also be assessed by orally administered inert or metabolic active probes, which can be differentially transported through the intestinal epithelium and detected in the blood or urine. For example, lactulose/mannitol ratio in urine is informative on detecting the small intestine permeability, while increased levels of sucrose or sucralose excretion are associated with large intestine permeability [272]. However, the development of a unique gold standard and complete evaluation of this phenomenon are needed, since only $39 \%$ of NAFLD patients and $49 \%$ of NASH patients have demonstrated intestinal permeability [273].

Increased intestinal permeability has been found in several conditions including exposure to HFD, specific microbiota, gliadin, allergens or even hyperglycemia $[227,269]$. Thaiss et al. clearly showed that hyperglycemia drives intestinal permeability by the glucose transporter GLUT2-dependent transcriptional reprogramming of intestinal epithelial cells, resulting in changes in tight and adherence junction integrity, and a systemic influx of microbial products into portal blood [274]. Moreover, the inflammasome, a multiprotein complex that orchestrates host defense mechanisms against infectious agents, appears to be also linked to intestinal permeability. HFD impinged intestinal permeability which was more pronounced in the NLRP3-inflammasome deficient mice in a ZO-1 dependent manner [227]. This phenomenon was associated with changes in diet-induced anti-microbial peptides secretion 
and with an inflammasome-dependent downregulation of angiogenin-4, an intestinal protein with important antibacterial functions [227]. The authors proposed that the combination of a Western lifestyle diet with inflammasome alteration modified antimicrobial activity, which might lead to a boosted abundance of mucus degrading bacteria, allowing passage of pathogens into the portal circulation [227]. Another mechanism involved in the regulation of intestinal barrier function is the COX-2/prostaglandin E2 (PGE2)/EP-2/p-ERK integrated signal pathways that modulate the expression of intestinal ZO-1 and cell adhesion molecule E-cadherin [275]. Gao J et al. observed that the restore of the COX-2/prostaglandin E2 (PGE2)/EP-2/p-ERK pathway using celecoxib in a thioacetamide rat model improved intestinal permeability by blocking the inflammatory response, as shown by decreased levels of LPS, tumor necrosis factor (TNF)- $\alpha$ and interleukin (IL)-6, thus reducing the progression of liver injury to cirrhosis [275].

\subsection{Gut Permeability and Bacterial Translocations}

Bacterial translocation can be defined as the passage of bacteria, or bacterial products such as LPS, into the portal circulation and happens when the complex regulation of the mechanisms of the gut barrier is lost [276], which has been linked with the occurrence of NAFLD, NASH, hepatic fibrosis, and HCC in several rodent models $[227,228,277]$. The association between increased gut permeability and NAFLD has also been demonstrated in human studies, and bacterial translocation occurs in those patients that develop NASH, at least in a pediatric study [278]. In NASH patients, serum LPS and hepatocytes LPS localization was higher than controls, which was correlated with serum zonulin and pNF- $\kappa B$ expression [279]. Recently it has been shown that disruption of the intestinal epithelial barrier and gut vascular barrier are early events in NASH pathogenesis and that OCA is able to protect against barrier disruption and thereby prevents the development of NASH, providing further evidence for its use in the prevention or treatment of NASH [280].

Specifically, bacterial components can increase the expression of specific receptors, such as Toll-Like Receptors (TLRs). TLRs can bind PAPMs (small molecular motifs conserved within a class of microbes) and DAMPs (host biomolecules that can initiate and perpetuate a noninfectious inflammatory response) leading to increased gene expression of pro-inflammatory mediators such as TNF $\alpha$, IL-1 $\beta$, and interferons. In NASH, TLR4 (that recognizes LPS, a gram-negative bacteria wall component), TLR5 (known to recognize bacterial flagellin from invading mobile bacteria), TLR2 (that recognizes many bacterial, fungal, viral, and endogenous substances) and TLR9 (a specific receptor for double-stranded bacterial DNA) have been shown to play a key pathogenetic role [281]. Increased levels of LPS activate TLR4 and have been observed in the serum of steatotic patients and in diet-induced NAFLD/NASH models (HFD, fructose-rich diet, methionine/choline-deficient diet, and choline-deficient L-amino acid-defined diet), where lack of TLR4 showed reduced liver damage, in terms of steatosis or steatohepatitis $[279,282]$. Similar results indicating a pathogenetic role of TLR have been obtained also for TLR9 using the choline-deficient L-amino acid-defined diet model of NASH [283]. Furthermore, FAs also have been recognized as TLR4 ligands that can activate pro-inflammatory signaling leading to TNF $\alpha$ secretion [284]. In a HFD plus fructose model of NASH, liver injury development was associated with dysbiosis, bacterial translocation mediated by alterations in intestinal permeability due to reduced tight junctions' expression, and reduced gut antimicrobial capacity. These results indicate that complex interactions between the diet, the innate immunity, bacteria and intestinal function occurs in the development of NASH [226,227], and similar observations were obtained in experimental models of HCC development [285-287].

TLRs signaling can also act via the activation of inflammasomes. Once activated, the inflammasomes trigger an intracellular cascade which results in the secretion of pro-inflammatory and pro-fibrotic IL-1 $\beta$ and IL-18. Either in patients with NASH or animal models, the expression of inflammasome components was increased, indicating the potential role in the pathogenesis of liver injury $[226,227,288-291]$. The mechanisms behind the effects of the inflammasomes in NAFLD are complex and might involve metabolic, inflammatory and pro-fibrogenic effect in the liver (either parenchymal and 
in non-parenchymal cells), adipose tissue, and immune system. In the last few years, the role of the inflammasome in the modification of the gut microbiota have been highlighted. The inflammasome can indeed strongly affect gut microbiota composition as deletion of inflammasome components was associated with loss of epithelial integrity and gut inflammation associated with dysbiosis and bacteremia [292].

In comparison with healthy controls, patients with NASH are more likely to present an increased intestinal permeability. Luther et al. [273] also showed that an initial stage of hepatic damage and inflammation is associated with an alteration in intestinal permeability. Moreover, intestinal permeability and the prevalence of small intestinal bacterial overgrowth are correlated with the severity of liver steatosis [293]. The same pattern is seen in obese subjects with steatosis who present an increase in intestinal permeability in comparison with obese patients [294]. Patients with NAFLD ranging from simple NAFLD to NASH showed higher intestinal permeability as assessed by a lactulose/mannitol test, alcohol, and endotoxin levels in plasma in comparison with controls [295]. It has been also shown that individuals with celiac disease, characterized by increased gut permeability, are at increased risk of NAFLD compared to the general population [296,297].

\subsection{Gut-Derived Inflammatory Mediators Triggering NAFLD/NASH}

The increase in gut permeability allows a constant flow of pro-inflammatory mediators to the liver, which firstly target the liver resident macrophages, the Kupffer cells. Several compounds bind to TLRs expressed in Kupffer cells and also in hepatic stellate cells, namely methylamine, volatile organic compounds and pathogen-associated molecular patterns, which include LPS, lipoteichoic acid, peptidoglycan, flagellin and unmethylated CpG DNA, and activate inflammatory signaling pathways like the NF-kB [298]. Kupffer cell activation results in a subclinical hepatic inflammatory state that may lead to the development of NAFLD/NASH. Of relevance among TLRs, TLR4 identifies LPS from gram-negative bacteria and TLR9 recognizes bacteria-derived GpG-containing DNA. Hence, TLR4 knockout mice show protection towards the manifestation of liver injury. Even though Kupffer cells contain the highest expression of TLR4, stellate cells TLR4 signaling appear to be critical in transforming growth factor $\beta$ secretion and fibrosis development in a myeloid differentiation primary response 88 (MyD88) dependent manner [299]. Kupffer cells are not only sensitive to inflammatory signals but also to metabolic challenges such as dyslipidemia, which affects Kupffer cell activation in models of liver steatosis and steatohepatitis [300,301]. Another molecule that has been implicated in liver fibrosis resolution is DPP-4/CD26, whose increased circulating activity is inversely correlated with a drastic reduction in Kupffer cell population upon liver injury [302]. Latest studies strongly suggest that Western diet-fed mice under inflamed gut conditions driven by dextran sulfate sodium $1 \%$ exacerbate hepatic steatosis, inflammation and fibrosis progression with increased IL-1, IL-6, TNF- $\alpha$, monocyte chemoattractant protein (MCP)-1 and profibrogenic factors, such as transforming growth factor (TGF)- $\beta, \alpha 2$-Actin, tissue inhibitor of metalloproteinase (TIMP)- 1 and plasminogen activator inhibitor (PAI)-1 [303].

\section{Targeting the Gut Permeability to Improve NAFLD/NASH}

Two types of strategies can be used to improve gut permeability to target NAFLD/NASH pathogenesis and progression. The first one is to address gut microbiota in a way that gut inflammation is rescued, and permeability is restored. The second strategy is to target gut inflammation/permeability itself but there are still a few therapeutic strategies nowadays.

For the first strategy, a pharmacological approach to simultaneously impact on the microbiota and the gut permeability and ultimately target the liver can be applied. Biguanides/metformin, the first-line therapeutics for T2D, modifies microbiota leading to an increase in A. muciniphila, as well as several SCFA-producing microbiota, favoring an improvement on mucin-producing goblet cells, pro-inflammatory IL-6, and glucose tolerance [304]. A direct effect of metformin on the ileal epithelial barrier was also observed and the authors associated this improvement to increased activation of 
AMPK [305]. In another study, metformin improved tight junction integrity and permeability by increasing occludin-1 levels and increasing A. muciniphila levels [306]. Thus, metformin not only directly improved NAFLD but also affected the epithelial intestinal barrier.

Similarly, DPP-4 inhibitors are also able to modify gut microbiota by increasing Firmicutes and Tenericutes phyla and decreasing Bacteroidetes in DIO rodents [307]. Nonetheless, vildagliptin reduces Firmicutes to Bacteroidetes ratio, increases Lactobacilli spp. and increases propionate production [308]. Moreover, Olivares et al. suggested that this vildagliptin effect is in part due to its properties on the microbiota-derived DPP-4 [191]. Regarding GLP-1RA, scarce literature is available. However, liraglutide appears to enhance SCFA-producing bacteria including Bacteroides, Lachnospiraceae and probiotic bacteria, Bifidobacterium, and the authors attribute the change in local inflammation to this gut microbiota structural modifications [309]. Whether individuals that are more responsive to GLP-1 secretion have a gut microbiota more shielded towards NAFLD and dysmetabolism is unveiled. The SGLT2 inhibitor dapagliflozin also showed some improvement in NAFLD, affecting microbiota by promoting a reduction of the Firmicutes/Bacteroidetes ratio in diabetic mice [310]. As previously described, disruption of the intestinal epithelial barrier and gut vascular barrier represents early events in NASH pathogenesis and are mediated by the occurrence of dysbiosis. OCA repairs these impairments through its FXR-dependent effect [280]. It has been already demonstrated that intestinal FXR modifies the gut microbiota and activates the TGR5/GLP-1 axis and this lead to improvement of hepatic glucose and insulin sensitivity and increase adipose tissue browning [311]. These studies reinforce the hypothesis of a direct link between intestinal nuclear receptors and gut microbiota in modifying the gut-liver axis function in the host metabolic control.

More recently, a few papers have evaluated the role of A. Muciniphila [312-314]. In humans, studies have provided evidence for a negative correlation between A. Muciniphila abundance and overweight, obesity, untreated T2D or hypertension. In mice, it has been shown that administration of A. Muciniphila prevents the development of obesity and associated complications. However, the sensitivity of $A$. Muciniphila to oxygen limited the development of translational approaches for human medicine. However, it was found that both pasteurization of A. Muciniphila and a specific protein isolated from its outer membrane (Amuc_1100) recapitulates the beneficial effect of the entire bacterium facilitating the possibility of its use in clinical trial in humans. In a proof-of-concept study, administration of live or pasteurized A. Muciniphila improved insulin sensitivity and reduced insulinemia and plasma total cholesterol without affecting body weight, fat mass and hip circumference.

Moreover, the beneficial effects of probiotics in the modulation of gut microbiota to achieve metabolic improvements in the host are minimal [315]. In a preliminary report, human-to-human fecal microbial transplantation has demonstrated a beneficial influence of the microbiota from a lean donor in obese recipients, resulting in improved insulin sensitivity [316].

However, no further data are available on direct manipulation of gut microbiota. Several signs of progress have been made on knowledge of NASH pathogenesis, but several aspects still need to be clarified and they are mostly related to the gut-liver axis mechanisms. This is the reason why there is nowadays a lack of effective therapies directly targeting the gut-microbiota-liver axis for the treatment of NASH and its progression to hepatic cirrhosis and end-stage liver disease.

\section{Conclusions}

Currently, available data reviewed herein suggest a role for GLP-1RA in ameliorating hepatic insulin resistance and improving NAFLD with beneficial effects on hepatic lipid metabolism. Given their beneficial effects on liver enzymes, weight loss and hepatic metabolism, GLP-1RA (currently approved for the treatment of diabetic hyperglycemia and obesity) may prove to be an effective treatment for NAFLD/NASH in nondiabetic subjects, as well as individuals with diabetes. Because DPP-4 inhibitors do not increase (only prolong) the elevation of circulating GLP-1 levels nor induce major weight loss, it is unclear whether they will have a significant beneficial effect on the prevention/treatment of NASH/NAFLD, as opposed to the GLP-1RA which are administered in pharmacologic amounts. 
Further studies are required to assess their efficacy, mechanism of action, and safety of GLP-1RA and DPP-4 inhibitors in patients with NAFLD/NASH. Other drugs with known beneficial effects on NASH (pioglitazone) or with significant effects in phase 2 (GLP-1RA) or 3 (FXR agonists) trial indicate the key role of gut-liver axis alterations in promoting the progression of NAFLD to NASH. Although alterations in gut microbiota have been associated with obesity and NAFLD there is no evidence indicating that in humans a long-term change in gut bacterial composition can be achieved and improves NAFLD/NASH. A better knowledge of the mechanisms leading to increased intestinal permeability and small metabolites produced during dysbiosis will provide novel therapeutic targets to prevent the development and progression of NAFLD to NASH.

Author Contributions: Conceptualization, G.S.-B., A.G. and M.P.M.; Searching PubMed, B.P., G.L.; writing-original draft preparation, G.S.-B., B.P. and A.G.; writing-review and editing, G.S.-B., M.P.M., G.L.; funding acquisition, A.G. and M.P.M. All authors have read and agreed to the published version of the manuscript.

Funding: This study was supported by internal funds of the Italian National Research Council (CNR, B54I19000370005). M.P.M. and A.G. acknowledge the financial support from the European Union's Horizon 2020 Research and Innovation Programme under the Marie Skłodowska-Curie Grant Agreement No. 722619 (FOIE GRAS project) and Grant Agreement No. 734719 (mtFOIE GRAS project), and BP is recipient of an Early Stage Researcher grant under the FOIE GRAS project. M.P.M. also acknowledge the financial support from PTDC/BIM-MET/2115/2014 and PTDC/MEC-MET/29314/2017; and iNOVA4Health (UID/Multi/04462/2013).

Conflicts of Interest: The authors have no potential conflict of interest relevant to this article.

\section{Abbreviations}

$\begin{array}{ll}\text { ALT } & \text { Alanine aminotransferase } \\ \text { AMPK } & \text { AMP-activated protein kinase } \\ \text { APRI } & \text { AST to platelet ratio index } \\ \text { AST } & \text { Aspartate aminotransferase } \\ \text { BA } & \text { Bile acids } \\ \text { BMI } & \text { Body mass index } \\ \text { CM } & \text { Chylomicron } \\ \text { CYP } & \text { Cytochrome P450 } \\ \text { DCA } & \text { Deoxycholic acid } \\ \text { DIO } & \text { Diet-induced obesity } \\ \text { DPP-4 } & \text { Dipeptidyl peptidase } 4 \\ \text { FXR } & \text { Farnesoid X receptor } \\ \text { FGF } & \text { Fibroblast growth factor } \\ \text { FFA } & \text { Free fatty acid } \\ \text { GCDCA } & \text { Glycolchenodeoxycholic acid } \\ \text { GIP } & \text { Glucose-dependent insulinotropic peptide } \\ \text { GLP-1 } & \text { Glucagon-like peptide-1 } \\ \text { GLP-1RA } & \text { GLP-1 receptor agonists } \\ \text { GPCR } & \text { G-protein-coupled receptors } \\ \text { HbA1c } & \text { Glycosylated hemoglobin } \\ \text { HCC } & \text { Hepatocellular carcinoma } \\ \text { HFD } & \text { High-fat diet } \\ \text { IL } & \text { Interleukin } \\ \text { LCA } & \text { Lithocholic acid } \\ \text { LPS } & \text { Lipopolysaccharide } \\ \text { NAFLD } & \text { Non-alcoholic fatty liver disease } \\ \text { NASH } & \text { Non-alcoholic steatohepatitis } \\ \text { OCA } & \text { Obeticholic acid } \\ \text { PPAR } & \text { Peroxisome proliferator-activated receptor } \\ \text { RLP } & \text { Remnant lipoprotein } \\ \text { SCFA } & \text { Short-chain fatty acids } \\ \text { STAT3 } & \text { Signal transducer and activator of transcription 3 } \\ \text { T2D } & \text { Type-2 diabetes } \\ & \end{array}$


TCDCA Taurochenodeoxycholic acid

TG Triglycerides

T2D Type-2 diabetes

TLR Toll-Like Receptors

TNF Tumor necrosis factor

VLDL Very low-density lipoprotein particles

ZO-1 Zonula occludens-1

\section{References}

1. Younossi, Z.; Tacke, F.; Arrese, M.; Chander Sharma, B.; Mostafa, I.; Bugianesi, E.; Wai-Sun Wong, V.; Yilmaz, Y.; George, J.; Fan, J.; et al. Global Perspectives on Nonalcoholic Fatty Liver Disease and Nonalcoholic Steatohepatitis. Hepatology 2019, 69, 2672-2682. [CrossRef] [PubMed]

2. Bedossa, P.; Tordjman, J.; Aron-Wisnewsky, J.; Poitou, C.; Oppert, J.M.; Torcivia, A.; Bouillot, J.L.; Paradis, V.; Ratziu, V.; Clement, K. Systematic review of bariatric surgery liver biopsies clarifies the natural history of liver disease in patients with severe obesity. Gut 2017, 66, 1688-1696. [CrossRef] [PubMed]

3. Souto, K.P.; Meinhardt, N.G.; Ramos, M.J.; Ulbrich-Kulkzynski, J.M.; Stein, A.T.; Damin, D.C. Nonalcoholic fatty liver disease in patients with different baseline glucose status undergoing bariatric surgery: Analysis of intraoperative liver biopsies and literature review. Surg. Obes. Relat. Dis. 2018, 14, 66-73. [CrossRef] [PubMed]

4. Day, C.P.; James, O.F. Steatohepatitis: A tale of two "hits"? Gastroenterology 1998, 114, 842-845. [CrossRef]

5. Tilg, H.; Moschen, A.R. Evolution of inflammation in nonalcoholic fatty liver disease: The multiple parallel hits hypothesis. Hepatology 2010, 52, 1836-1846. [CrossRef]

6. Sun, E.W.L.; Martin, A.M.; Young, R.L.; Keating, D.J. The Regulation of Peripheral Metabolism by Gut-Derived Hormones. Front. Endocrinol. 2018, 9, 754. [CrossRef]

7. Herrmann, C.; Goke, R.; Richter, G.; Fehmann, H.C.; Arnold, R.; Goke, B. Glucagon-like peptide-1 and glucose-dependent insulin-releasing polypeptide plasma levels in response to nutrients. Digestion 1995, 56, 117-126. [CrossRef]

8. Drucker, D.J.; Nauck, M.A. The incretin system: Glucagon-like peptide-1 receptor agonists and dipeptidyl peptidase-4 inhibitors in type 2 diabetes. Lancet 2006, 368, 1696-1705. [CrossRef]

9. McCaughan, G.W.; Gorrell, M.D.; Bishop, G.A.; Abbott, C.A.; Shackel, N.A.; McGuinness, P.H.; Levy, M.T.; Sharland, A.F.; Bowen, D.G.; Yu, D.; et al. Molecular pathogenesis of liver disease: An approach to hepatic inflammation, cirrhosis and liver transplant tolerance. Immunol. Rev. 2000, 174, 172-191. [CrossRef]

10. Mentzel, S.; Dijkman, H.B.; Van Son, J.P.; Koene, R.A.; Assmann, K.J. Organ distribution of aminopeptidase A and dipeptidyl peptidase IV in normal mice. J. Histochem. Cytochem. 1996, 44, 445-461. [CrossRef]

11. Kikuchi, M.; Fukuyama, K.; Epstein, W.L. Soluble dipeptidyl peptidase IV from terminal differentiated rat epidermal cells: Purification and its activity on synthetic and natural peptides. Arch. Biochem. Biophys. 1988, 266, 369-376. [CrossRef]

12. Parker, H.E.; Reimann, F.; Gribble, F.M. Molecular mechanisms underlying nutrient-stimulated incretin secretion. Expert Rev. Mol. Med. 2010, 12, e1. [CrossRef] [PubMed]

13. Fava, G.E.; Dong, E.W.; Wu, H. Intra-islet glucagon-like peptide 1. J. Diabetes Complicat. 2016, 30, 1651-1658. [CrossRef] [PubMed]

14. Dupre, J.; Ross, S.A.; Watson, D.; Brown, J.C. Stimulation of insulin secretion by gastric inhibitory polypeptide in man. J. Clin. Endocrinol. Metab. 1973, 37, 826-828. [CrossRef]

15. Kreymann, B.; Williams, G.; Ghatei, M.A.; Bloom, S.R. Glucagon-like peptide-1 7-36: A physiological incretin in man. Lancet 1987, 2, 1300-1304. [CrossRef]

16. Campbell, J.E.; Drucker, D.J. Pharmacology, physiology, and mechanisms of incretin hormone action. Cell Metab. 2013, 17, 819-837. [CrossRef]

17. Holst, J.J. Glucagon-like peptide-1: From extract to agent. The Claude Bernard Lecture, 2005. Diabetologia 2006, 49, 253-260. [CrossRef]

18. Nauck, M.A.; Heimesaat, M.M.; Behle, K.; Holst, J.J.; Nauck, M.S.; Ritzel, R.; Hüfner, M.; Schmiegel, W.H. Effects of glucagon-like peptide 1 on counterregulatory hormone responses, cognitive functions, and insulin secretion during hyperinsulinemic, stepped hypoglycemic clamp experiments in healthy volunteers. J. Clin. Endocrinol. Metab. 2002, 87, 1239-1246. [CrossRef] 
19. Meier, J.J.; Gallwitz, B.; Siepmann, N.; Holst, J.J.; Deacon, C.F.; Schmidt, W.E.; Nauck, M.A. Gastric inhibitory polypeptide (GIP) dose-dependently stimulates glucagon secretion in healthy human subjects at euglycaemia. Diabetologia 2003, 46, 798-801. [CrossRef]

20. Vilsboll, T.; Krarup, T.; Madsbad, S.; Holst, J.J. Both GLP-1 and GIP are insulinotropic at basal and postprandial glucose levels and contribute nearly equally to the incretin effect of a meal in healthy subjects. Regul. Pept. 2003, 114, 115-121. [CrossRef]

21. Nauck, M.A.; Bartels, E.; Orskov, C.; Ebert, R.; Creutzfeldt, W. Additive insulinotropic effects of exogenous synthetic human gastric inhibitory polypeptide and glucagon-like peptide-1-(7-36) amide infused at near-physiological insulinotropic hormone and glucose concentrations. J. Clin. Endocrinol. Metab. 1993, 76, 912-917. [CrossRef] [PubMed]

22. Nauck, M.A.; Meier, J.J. The incretin effect in healthy individuals and those with type 2 diabetes: Physiology, pathophysiology, and response to therapeutic interventions. Lancet. Diabetes Endocrinol. 2016, 4, 525-536. [CrossRef]

23. Nauck, M.A.; Heimesaat, M.M.; Orskov, C.; Holst, J.J.; Ebert, R.; Creutzfeldt, W. Preserved incretin activity of glucagon-like peptide 1 [7-36 amide] but not of synthetic human gastric inhibitory polypeptide in patients with type-2 diabetes mellitus. J. Clin. Investig. 1993, 91, 301-307. [CrossRef] [PubMed]

24. Gastaldelli, A.; Gaggini, M.; Daniele, G.; Ciociaro, D.; Cersosimo, E.; Tripathy, D.; Triplitt, C.; Fox, P.; Musi, N.; DeFronzo, R.; et al. Exenatide improves both hepatic and adipose tissue insulin resistance: A dynamic positron emission tomography study. Hepatology 2016, 64, 2028-2037. [CrossRef] [PubMed]

25. Nauck, M.A.; Wollschlager, D.; Werner, J.; Holst, J.J.; Orskov, C.; Creutzfeldt, W.; Willms, B. Effects of subcutaneous glucagon-like peptide 1 (GLP-1 [7-36 amide]) in patients with NIDDM. Diabetologia 1996, 39, 1546-1553. [CrossRef] [PubMed]

26. Daniele, G.; Iozzo, P.; Molina-Carrion, M.; Lancaster, J.; Ciociaro, D.; Cersosimo, E.; Tripathy, D.; Triplitt, C.; Fox, P.; Musi, N.; et al. Exenatide Regulates Cerebral Glucose Metabolism in Brain Areas Associated With Glucose Homeostasis and Reward System. Diabetes 2015, 64, 3406-3412. [CrossRef] [PubMed]

27. Holst, J.J. The incretin system in healthy humans: The role of GIP and GLP-1. Metabolism 2019, 96, 46-55. [CrossRef]

28. Muscogiuri, G.; DeFronzo, R.A.; Gastaldelli, A.; Holst, J.J. Glucagon-like Peptide-1 and the Central/Peripheral Nervous System: Crosstalk in Diabetes. Trends Endocrinol. Metab. 2017, 28, 88-103. [CrossRef]

29. Flint, A.; Raben, A.; Astrup, A.; Holst, J.J. Glucagon-like peptide 1 promotes satiety and suppresses energy intake in humans. J. Clin. Investig. 1998, 101, 515-520. [CrossRef]

30. Gasbjerg, L.S.; Helsted, M.M.; Hartmann, B.; Jensen, M.H.; Gabe, M.B.N.; Sparre-Ulrich, A.H.; Veedfald, S.; Stensen, S.; Lanng, A.R.; Bergmann, N.C.; et al. Separate and Combined Glucometabolic Effects of Endogenous Glucose-Dependent Insulinotropic Polypeptide and Glucagon-like Peptide 1 in Healthy Individuals. Diabetes 2019, 68, 906-917. [CrossRef]

31. Vilsboll, T.; Krarup, T.; Sonne, J.; Madsbad, S.; Volund, A.; Juul, A.G.; Holst, J.J. Incretin secretion in relation to meal size and body weight in healthy subjects and people with type 1 and type 2 diabetes mellitus. J. Clin. Endocrinol. Metab. 2003, 88, 2706-2713. [CrossRef] [PubMed]

32. Iepsen, E.W.; Lundgren, J.; Holst, J.J.; Madsbad, S.; Torekov, S.S. Successful weight loss maintenance includes long-term increased meal responses of GLP-1 and PYY3-36. Eur. J. Endocrinol. 2016, 174, 775-784. [CrossRef] [PubMed]

33. Ueda, S.Y.; Yoshikawa, T.; Katsura, Y.; Usui, T.; Fujimoto, S. Comparable effects of moderate intensity exercise on changes in anorectic gut hormone levels and energy intake to high intensity exercise. J. Endocrinol. 2009, 203, 357-364. [CrossRef] [PubMed]

34. Vilsboll, T.; Christensen, M.; Junker, A.E.; Knop, F.K.; Gluud, L.L. Effects of glucagon-like peptide-1 receptor agonists on weight loss: Systematic review and meta-analyses of randomised controlled trials. BMJ 2012, 344, d7771. [CrossRef] [PubMed]

35. Bunck, M.C.; Corner, A.; Eliasson, B.; Heine, R.J.; Shaginian, R.M.; Taskinen, M.R.; Smith, U.; Yki-Jarvinen, H.; Diamant, M. Effects of exenatide on measures of beta-cell function after 3 years in metformin-treated patients with type 2 diabetes. Diabetes Care 2011, 34, 2041-2047. [CrossRef] 
36. Nauck, M.; Frid, A.; Hermansen, K.; Thomsen, A.B.; During, M.; Shah, N.; Tankova, T.; Mitha, I.; Matthews, D.R. Long-term efficacy and safety comparison of liraglutide, glimepiride and placebo, all in combination with metformin in type 2 diabetes: 2-year results from the LEAD-2 study. Diabetesobesity Metab. 2013, 15, 204-212. [CrossRef]

37. Buse, J.B.; Nauck, M.; Forst, T.; Sheu, W.H.; Shenouda, S.K.; Heilmann, C.R.; Hoogwerf, B.J.; Gao, A.; Boardman, M.K.; Fineman, M.; et al. Exenatide once weekly versus liraglutide once daily in patients with type 2 diabetes (DURATION-6): A randomised, open-label study. Lancet 2013, 381, 117-124. [CrossRef]

38. DeFronzo, R.A.; Triplitt, C.; Qu, Y.; Lewis, M.S.; Maggs, D.; Glass, L.C. Effects of exenatide plus rosiglitazone on beta-cell function and insulin sensitivity in subjects with type 2 diabetes on metformin. Diabetes Care 2010, 33, 951-957. [CrossRef]

39. Grimm, M.; Han, J.; Weaver, C.; Griffin, P.; Schulteis, C.T.; Dong, H.; Malloy, J. Efficacy, safety, and tolerability of exenatide once weekly in patients with type 2 diabetes mellitus: An integrated analysis of the DURATION trials. Postgrad. Med. 2013, 125, 47-57. [CrossRef]

40. Choi, I.Y.; Kim, J.K.; Lee, J.S.; Park, E.; Kim, Y.H.; Jung, S.Y.; Kim, S.J. Effect of a Novel Long-Acting GLP-1/GIP/Glucagon Triple Agonist (HM15211) in a NASH and Fibrosis Animal Model. Diabetes 2018, 67, 1106-P. [CrossRef]

41. Choi, J.; Kim, J.K.; Lee, S.M.; Kwon, H.; Lee, J.; Bae, S.; Kim, D.; Choi, I.Y. 1830-P: Therapeutic Effect of a Novel Long-Acting GLP-1/GIP/Glucagon Triple Agonist (HM15211) in CDHFD-Induced NASH and Fibrosis Mice. Diabetes 2020, 69, 1830-P. [CrossRef]

42. Choi, J.D.; Baek, S.; Kim, Y.; Eun, K.; Kwon, S.C.; Morrow, L.; Hompesch, M.; Kang, J. 982-P: A DoubleBlinded, Placebo Controlled, Single Ascending Dose Study for Safety, Tolerability, Pharmacokinetics, and Pharmacodynamics after Subcutaneous Administration of Novel Long-Acting GLP-1/GIP/Glucagon Triple Agonist (HM15211) in Healthy Obese Subjects. Diabetes 2019, 68, 982-P. [CrossRef]

43. DePaoli, A.; Bashir, M.; Phung, V.; Yan, A.; Ling, L.; Baxter, B.; Tian, H. PS-108-NGM, a novel activator of beta-Klotho/FGFR1c: A single dose significantly reduces steatosis (liver fat by MRI-PDFF), inflammation (ALT, AST) and fibrogenic activity (Pro-C3) in NAFLD subjects. J. Hepatol. 2019, 70, e68-e69. [CrossRef]

44. Depaoli, A.; Phung, V.A.N.; Bashir, M.R.; Morrow, L.; Beysen, C.; Yan, A.; Ling, L.E.I.; Baxter, B.; Luskey, K.L.; Olefsky, J.M. 140-LB: NGM313, a Novel Activator of b-Klotho/FGFR1c, Improves Insulin Resistance and Reduces Hepatic Fat in Obese, Nondiabetic Subjects. Diabetes 2019, 68, 140-LB. [CrossRef]

45. Heise, T.; Morrow, L.; Hompesch, M.; Haring, H.U.; Kapitza, C.; Abt, M.; Ramsauer, M.; Magnone, M.C.; Fuerst-Recktenwald, S. Safety, efficacy and weight effect of two 11beta-HSD1 inhibitors in metformin-treated patients with type 2 diabetes. Diabetes Obes. Metab. 2014, 16, 1070-1077. [CrossRef] [PubMed]

46. Stefan, N.; Ramsauer, M.; Jordan, P.; Nowotny, B.; Kantartzis, K.; Machann, J.; Hwang, J.H.; Nowotny, P.; Kahl, S.; Harreiter, J.; et al. Inhibition of 11beta-HSD1 with RO5093151 for non-alcoholic fatty liver disease: A multicentre, randomised, double-blind, placebo-controlled trial. Lancet Diabetes Endocrinol. 2014, 2, 406-416. [CrossRef]

47. Acton, J.J., 3rd; Akiyama, T.E.; Chang, C.H.; Colwell, L.; Debenham, S.; Doebber, T.; Einstein, M.; Liu, K.; McCann, M.E.; Moller, D.E.; et al. Discovery of (2R)-2-(3-\{3-[(4-Methoxyphenyl)carbonyl]-2methyl-6-(trifluoromethoxy)-1H-indol-1 -yl\}phenoxy)butanoic acid (MK-0533): A novel selective peroxisome proliferator-activated receptor gamma modulator for the treatment of type 2 diabetes mellitus with a reduced potential to increase plasma and extracellular fluid volume. J. Med. Chem. 2009, 52, 3846-3854. [CrossRef]

48. Ida, S.; Kaneko, R.; Murata, K. Efficacy and safety of pemafibrate administration in patients with dyslipidemia: A systematic review and meta-analysis. Cardiovasc. Diabetol. 2019, 18, 38. [CrossRef]

49. Kaul, U.; Parmar, D.; Manjunath, K.; Shah, M.; Parmar, K.; Patil, K.P.; Jaiswal, A. New dual peroxisome proliferator activated receptor agonist-Saroglitazar in diabetic dyslipidemia and non-alcoholic fatty liver disease: Integrated analysis of the real world evidence. Cardiovasc. Diabetol. 2019, 18, 80. [CrossRef]

50. Roy, S.; Ghosh, A. Significant Reduction of Elevated Triglycerides and Liver Fibrosis in Diabetic Dyslipidemia with Saroglitazar: A Case Report. Cureus 2019, 11, e6361. [CrossRef]

51. Zydus Cadila. World's First Drug for the Treatment of Non-Cirrhotic NASH. Press Release March 5. 2020. Available online: https://zyduscadila.com/public/pdf/pressrelease/Zydus_announces_world \T1\textquoteri ghts_first_drug_for_the_treatment_of_Non_Cirrhotic_NASH.pdf (accessed on 4 August 2020). 
52. Boubia, B.; Poupardin, O.; Barth, M.; Binet, J.; Peralba, P.; Mounier, L.; Jacquier, E.; Gauthier, E.; Lepais, V.; Chatar, M.; et al. Design, Synthesis, and Evaluation of a Novel Series of Indole Sulfonamide Peroxisome Proliferator Activated Receptor (PPAR) alpha/gamma/delta Triple Activators: Discovery of Lanifibranor, a New Antifibrotic Clinical Candidate. J. Med. Chem. 2018, 61, 2246-2265. [CrossRef] [PubMed]

53. Inventiva. Lanifibranor Meets the Primary and Key Secondary Endpoints in the Phase IIb NATIVE Cinical Trial in Non-alcoholic Steatohepatitis (NASH). Press Release June 15. 2020. Available online: https://www.globenewswire.com/news-release/2020/06/15/2048284/0/en/Inventiva-s-lanifibranor-meets-th e-primary-and-key-secondary-endpoints-in-the-Phase-IIb-NATIVE-clinical-trial-in-non-alcoholic-steato hepatitis-NASH.html (accessed on 4 August 2020).

54. Lucas, K.J.; Lopez, P.; Lawitz, E.; Sheikh, A.; Aizenberg, D.; Hsia, S.; Bee, G.G.B.; Vierling, J.; Frias, J.; White, J.; et al. Tropifexor, a highly potent FXR agonist, produces robust and dose-dependent reductions in hepatic fat and serum alanine aminotransferase in patients with fibrotic NASH after 12 weeks of therapy: FLIGHT-FXR Part C interim results. Dig. Liver Dis. 2020, 52, e38. [CrossRef]

55. Tully, D.C.; Rucker, P.V.; Chianelli, D.; Williams, J.; Vidal, A.; Alper, P.B.; Mutnick, D.; Bursulaya, B.; Schmeits, J.; Wu, X.; et al. Discovery of Tropifexor (LJN452), a Highly Potent Non-bile Acid FXR Agonist for the Treatment of Cholestatic Liver Diseases and Nonalcoholic Steatohepatitis (NASH). J. Med. Chem. 2017, 60, 9960-9973. [CrossRef] [PubMed]

56. Patel, K.; Harrison, S.A.; Elkashab, M.; Trotter, J.F.; Herring, R.; Rojter, S.; Kayali, Z.; Wong, V.W.; Greenbloom, S.; Jayakumar, S.; et al. Cilofexor, a Nonsteroidal FXR Agonist, in Non-Cirrhotic Patients with Nonalcoholic Steatohepatitis: A Phase 2 Randomized Controlled Trial. Hepatology 2020, 72, 58-71. [CrossRef]

57. Trauner, M.; Gulamhusein, A.; Hameed, B.; Caldwell, S.; Shiffman, M.L.; Landis, C.; Eksteen, B.; Agarwal, K.; Muir, A.; Rushbrook, S.; et al. The Nonsteroidal Farnesoid X Receptor Agonist Cilofexor (GS-9674) Improves Markers of Cholestasis and Liver Injury in Patients With Primary Sclerosing Cholangitis. Hepatology 2019, 70, 788-801. [CrossRef]

58. DePaoli, A.M.; Zhou, M.; Kaplan, D.D.; Hunt, S.C.; Adams, T.D.; Learned, R.M.; Tian, H.; Ling, L. FGF19 Analog as a Surgical Factor Mimetic That Contributes to Metabolic Effects Beyond Glucose Homeostasis. Diabetes 2019, 68, 1315-1328. [CrossRef] [PubMed]

59. Harrison, S.A.; Rinella, M.E.; Abdelmalek, M.F.; Trotter, J.F.; Paredes, A.H.; Arnold, H.L.; Kugelmas, M.; Bashir, M.R.; Jaros, M.J.; Ling, L.; et al. NGM282 for treatment of non-alcoholic steatohepatitis: A multicentre, randomised, double-blind, placebo-controlled, phase 2 trial. Lancet 2018, 391, 1174-1185. [CrossRef]

60. Harrison, S.A.; Rossi, S.J.; Paredes, A.H.; Trotter, J.F.; Bashir, M.R.; Guy, C.D.; Banerjee, R.; Jaros, M.J.; Owers, S.; Baxter, B.A.; et al. NGM282 Improves Liver Fibrosis and Histology in 12 Weeks in Patients With Nonalcoholic Steatohepatitis. Hepatology 2020, 71, 1198-1212. [CrossRef]

61. Hirschfield, G.M.; Chazouilleres, O.; Drenth, J.P.; Thorburn, D.; Harrison, S.A.; Landis, C.S.; Mayo, M.J.; Muir, A.J.; Trotter, J.F.; Leeming, D.J.; et al. Effect of NGM282, an FGF19 analogue, in primary sclerosing cholangitis: A multicenter, randomized, double-blind, placebo-controlled phase II trial. J. Hepatol. 2019, 70, 483-493. [CrossRef]

62. Rinella, M.E.; Trotter, J.F.; Abdelmalek, M.F.; Paredes, A.H.; Connelly, M.A.; Jaros, M.J.; Ling, L.; Rossi, S.J.; DePaoli, A.M.; Harrison, S.A. Rosuvastatin improves the FGF19 analogue NGM282-associated lipid changes in patients with non-alcoholic steatohepatitis. J. Hepatol. 2019, 70, 735-744. [CrossRef]

63. Zhou, M.; Learned, R.M.; Rossi, S.J.; Tian, H.; DePaoli, A.M.; Ling, L. Therapeutic FGF19 promotes HDL biogenesis and transhepatic cholesterol efflux to prevent atherosclerosis. J. Lipid Res. 2019, 60, 550-565. [CrossRef] [PubMed]

64. Ambery, P.; Parker, V.E.; Stumvoll, M.; Posch, M.G.; Heise, T.; Plum-Moerschel, L.; Tsai, L.F.; Robertson, D.; Jain, M.; Petrone, M.; et al. MEDI0382, a GLP-1 and glucagon receptor dual agonist, in obese or overweight patients with type 2 diabetes: A randomised, controlled, double-blind, ascending dose and phase 2a study. Lancet 2018, 391, 2607-2618. [CrossRef]

65. Parker, V.E.R.; Robertson, D.; Wang, T.; Hornigold, D.C.; Petrone, M.; Cooper, A.T.; Posch, M.G.; Heise, T.; Plum-Moerschel, L.; Schlichthaar, H.; et al. Efficacy, Safety, and Mechanistic Insights of Cotadutide, a Dual Receptor Glucagon-Like Peptide-1 and Glucagon Agonist. J. Clin. Endocrinol. Metab. 2020, 105. [CrossRef] [PubMed] 
66. Skarbaliene, J.; Madsen, A.N.; Mouritzen, U.; Bak, H.H.; Just, R. Exploring the therapeutic potential of Glucagon/GLP-1 dual agonist ZP2929 in a mouse model of diet induced and biopsy-confirmed non-alcoholic steatohepatitis. J. Hepatol. 2017, 66, S102. [CrossRef]

67. Brandt, S.J.; Gotz, A.; Tschop, M.H.; Muller, T.D. Gut hormone polyagonists for the treatment of type 2 diabetes. Peptides 2018, 100, 190-201. [CrossRef]

68. He, Y.L.; Haynes, W.; Meyers, C.D.; Amer, A.; Zhang, Y.; Mahling, P.; Mendonza, A.E.; Ma, S.; Chutkow, W.; Bachman, E. The effects of licogliflozin, a dual SGLT1/2 inhibitor, on body weight in obese patients with or without diabetes. Diabetes Obes. Metab. 2019, 21, 1311-1321. [CrossRef]

69. Yokote, K.; Sano, M.; Tsumiyama, I.; Keefe, D. Dose-dependent reduction in body weight with LIK066 (licogliflozin) treatment in Japanese patients with obesity. Diabetes Obes. Metab. 2020, 22, 1102-1110. [CrossRef]

70. Rosenstock, M.; Ayalon, M.; Mansbach, H.; Liu, Y.; Margalit, M. LBP29 BIO89-100, a novel PEG-FGF21 analogue, is efficacious following weekly and every 2-week subcutaneous dosing in spontaneous diabetic cynomolgus monkeys. J. Hepatol. 2019, 70, e141-e382. [CrossRef]

71. Calle, R.; Bergman, A.; Somayaji, V.; Chidsey, K.; Kazierad, D. PS-110-Ketohexokinase inhibitor PF-06835919 administered for 6 weeks reduces whole liver fat as measured by magnetic resonance imaging-proton density fat fraction in subjects with non-alcoholic fatty liver disease. J. Hepatol. 2019, 70, e69-e70. [CrossRef]

72. Syed-Abdul, M.M.; Parks, E.J.; Gaballah, A.H.; Bingham, K.; Hammoud, G.M.; Kemble, G.; Buckley, D.; McCulloch, W.; Manrique-Acevedo, C. Fatty Acid Synthase Inhibitor TVB-2640 Reduces Hepatic de Novo Lipogenesis in Males With Metabolic Abnormalities. Hepatology 2019, 72, 103-118. [CrossRef]

73. Lawitz, E.J.; Coste, A.; Poordad, F.; Alkhouri, N.; Loo, N.; McColgan, B.J.; Tarrant, J.M.; Nguyen, T.; Han, L.; Chung, C.; et al. Acetyl-CoA Carboxylase Inhibitor GS-0976 for 12 Weeks Reduces Hepatic De Novo Lipogenesis and Steatosis in Patients With Nonalcoholic Steatohepatitis. Clin. Gastroenterol. Hepatol. Off. Clin. Pract. J. Am. Gastroenterol. Assoc. 2018, 16, 1983-1991.e3. [CrossRef] [PubMed]

74. Harrison, S.A.; Bashir, M.R.; Guy, C.D.; Zhou, R.; Moylan, C.A.; Frias, J.P.; Alkhouri, N.; Bansal, M.B.; Baum, S.; Neuschwander-Tetri, B.A.; et al. Resmetirom (MGL-3196) for the treatment of non-alcoholic steatohepatitis: A multicentre, randomised, double-blind, placebo-controlled, phase 2 trial. Lancet 2019, 394, 2012-2024. [CrossRef]

75. Colca, J.R.; McDonald, W.G.; Adams, W.J. MSDC-0602K, a metabolic modulator directed at the core pathology of non-alcoholic steatohepatitis. Expert Opin. Investig. Drugs 2018, 27, 631-636. [CrossRef] [PubMed]

76. Harrison, S.A.; Alkhouri, N.; Davison, B.A.; Sanyal, A.; Edwards, C.; Colca, J.R.; Lee, B.H.; Loomba, R.; Cusi, K.; Kolterman, O.; et al. Insulin sensitizer MSDC-0602K in non-alcoholic steatohepatitis: A randomized, double-blind, placebo-controlled phase Ilb study. J. Hepatol. 2020, 72, 613-626. [CrossRef]

77. Lee, Y.H.; Kim, J.H.; Kim, S.R.; Jin, H.Y.; Rhee, E.J.; Cho, Y.M.; Lee, B.W. Lobeglitazone, a Novel Thiazolidinedione, Improves Non-Alcoholic Fatty Liver Disease in Type 2 Diabetes: Its Efficacy and Predictive Factors Related to Responsiveness. J. Korean Med. Sci. 2017, 32, 60-69. [CrossRef]

78. DePaoli, A.M.; Higgins, L.S.; Henry, R.R.; Mantzoros, C.; Dunn, F.L.; Group, I.N.T.S. Can a selective PPARgamma modulator improve glycemic control in patients with type 2 diabetes with fewer side effects compared with pioglitazone? Diabetes Care 2014, 37, 1918-1923. [CrossRef]

79. Ratziu, V.; Harrison, S.A.; Francque, S.; Bedossa, P.; Lehert, P.; Serfaty, L.; Romero-Gomez, M.; Boursier, J.; Abdelmalek, M.; Caldwell, S.; et al. Elafibranor, an Agonist of the Peroxisome Proliferator-Activated Receptor-alpha and -delta, Induces Resolution of Nonalcoholic Steatohepatitis Without Fibrosis Worsening. Gastroenterology 2016, 150, 1147-1159.e5. [CrossRef]

80. Genfit. Results from Interim Analysis of RESOLVE-IT Phase 3 Trial of Elafibranor in Adults with NASH and Fibrosis. Press Release May 11. 2020. Available online: https://ml-eu.globenewswire.com/Resource/Downl $\mathrm{oad} / 38 \mathrm{e} 085 \mathrm{e} 1-66 \mathrm{f5}-4251-8 \mathrm{abe}-648 \mathrm{d0e7b} 9 \mathrm{ed1}$ (accessed on 4 August 2020).

81. Younossi, Z.M.; Ratziu, V.; Loomba, R.; Rinella, M.; Anstee, Q.M.; Goodman, Z.; Bedossa, P.; Geier, A.; Beckebaum, S.; Newsome, P.N.; et al. Obeticholic acid for the treatment of non-alcoholic steatohepatitis: Interim analysis from a multicentre, randomised, placebo-controlled phase 3 trial. Lancet 2019, 394, 2184-2196. [CrossRef]

82. Mudaliar, S.; Henry, R.R.; Sanyal, A.J.; Morrow, L.; Marschall, H.U.; Kipnes, M.; Adorini, L.; Sciacca, C.I.; Clopton, P.; Castelloe, E.; et al. Efficacy and safety of the farnesoid X receptor agonist obeticholic acid in patients with type 2 diabetes and nonalcoholic fatty liver disease. Gastroenterology 2013, 145, 574-582. [CrossRef] 
83. Neuschwander-Tetri, B.A.; Loomba, R.; Sanyal, A.J.; Lavine, J.E.; Van Natta, M.L.; Abdelmalek, M.F.; Chalasani, N.; Dasarathy, S.; Diehl, A.M.; Hameed, B.; et al. Farnesoid X nuclear receptor ligand obeticholic acid for non-cirrhotic, non-alcoholic steatohepatitis (FLINT): A multicentre, randomised, placebo-controlled trial. Lancet 2015, 385, 956-965. [CrossRef]

84. Frias, J.P.; Nauck, M.A.; Van, J.; Kutner, M.E.; Cui, X.; Benson, C.; Urva, S.; Gimeno, R.E.; Milicevic, Z.; Robins, D.; et al. Efficacy and safety of LY3298176, a novel dual GIP and GLP-1 receptor agonist, in patients with type 2 diabetes: A randomised, placebo-controlled and active comparator-controlled phase 2 trial. Lancet 2018, 392, 2180-2193. [CrossRef]

85. Hartman, M.L.; Sanyal, A.J.; Loomba, R.; Wilson, J.M.; Nikooienejad, A.; Bray, R.; Karanikas, C.A.; Duffin, K.L.; Robins, D.A.; Haupt, A. Effects of Novel Dual GIP and GLP-1 Receptor Agonist Tirzepatide on Biomarkers of Nonalcoholic Steatohepatitis in Patients With Type 2 Diabetes. Diabetes Care 2020, 43, 1352-1355. [CrossRef] [PubMed]

86. Frias, J.P.; Nauck, M.A.; Van, J.; Benson, C.; Bray, R.; Cui, X.; Milicevic, Z.; Urva, S.; Haupt, A.; Robins, D.A. Efficacy and tolerability of tirzepatide, a dual glucose-dependent insulinotropic peptide and glucagon-like peptide-1 receptor agonist in patients with type 2 diabetes: A 12-week, randomized, double-blind, placebo-controlled study to evaluate different dose-escalation regimens. Diabetes Obes. Metab. 2020, 22, 938-946. [CrossRef] [PubMed]

87. Frias, J.P.; Bastyr, E.J., 3rd; Vignati, L.; Tschop, M.H.; Schmitt, C.; Owen, K.; Christensen, R.H.; DiMarchi, R.D. The Sustained Effects of a Dual GIP/GLP-1 Receptor Agonist, NNC0090-2746, in Patients with Type 2 Diabetes. Cell Metab. 2017, 26, 343-352. [CrossRef] [PubMed]

88. Charles, E.D.; Neuschwander-Tetri, B.A.; Pablo Frias, J.; Kundu, S.; Luo, Y.; Tirucherai, G.S.; Christian, R. Pegbelfermin (BMS-986036), PEGylated FGF21, in Patients with Obesity and Type 2 Diabetes: Results from a Randomized Phase 2 Study. Obes. Silver Spring 2019, 27, 41-49. [CrossRef] [PubMed]

89. Sanyal, A.; Charles, E.D.; Neuschwander-Tetri, B.A.; Loomba, R.; Harrison, S.A.; Abdelmalek, M.F.; Lawitz, E.J.; Halegoua-DeMarzio, D.; Kundu, S.; Noviello, S.; et al. Pegbelfermin (BMS-986036), a PEGylated fibroblast growth factor 21 analogue, in patients with non-alcoholic steatohepatitis: A randomised, double-blind, placebo-controlled, phase 2a trial. Lancet 2019, 392, 2705-2717. [CrossRef]

90. Iruarrizaga-Lejarreta, M.; Varela-Rey, M.; Fernandez-Ramos, D.; Martinez-Arranz, I.; Delgado, T.C.; Simon, J.; Juan, V.G.; delaCruz-Villar, L.; Azkargorta, M.; Lavin, J.L.; et al. Role of Aramchol in steatohepatitis and fibrosis in mice. Hepatol. Commun. 2017, 1, 911-927. [CrossRef]

91. Safadi, R.; Konikoff, F.M.; Mahamid, M.; Zelber-Sagi, S.; Halpern, M.; Gilat, T.; Oren, R.; Group, F. The fatty acid-bile acid conjugate Aramchol reduces liver fat content in patients with nonalcoholic fatty liver disease. Clin. Gastroenterol. Hepatol. Off. Clin. Pract. J. Am. Gastroenterol. Assoc. 2014, 12, 2085-2091.e1. [CrossRef]

92. Belfort, R.; Harrison, S.A.; Brown, K.; Darland, C.; Finch, J.; Hardies, J.; Balas, B.; Gastaldelli, A.; Tio, F.; Pulcini, J.; et al. A placebo-controlled trial of pioglitazone in subjects with nonalcoholic steatohepatitis. N. Engl. J. Med. 2006, 355, 2297-2307. [CrossRef]

93. Sanyal, A.J.; Chalasani, N.; Kowdley, K.V.; McCullough, A.; Diehl, A.M.; Bass, N.M.; Neuschwander-Tetri, B.A.; Lavine, J.E.; Tonascia, J.; Unalp, A.; et al. Pioglitazone, vitamin E, or placebo for nonalcoholic steatohepatitis. N. Engl. J. Med. 2010, 362, 1675-1685. [CrossRef]

94. Bril, F.; Kalavalapalli, S.; Clark, V.C.; Lomonaco, R.; Soldevila-Pico, C.; Liu, I.C.; Orsak, B.; Tio, F.; Cusi, K. Response to Pioglitazone in Patients With Nonalcoholic Steatohepatitis With vs Without Type 2 Diabetes. Clin. Gastroenterol. Hepatol. Off. Clin. Pract. J. Am. Gastroenterol. Assoc. 2018, 16, 558-566. [CrossRef] [PubMed]

95. Cusi, K.; Orsak, B.; Bril, F.; Lomonaco, R.; Hecht, J.; Ortiz-Lopez, C.; Tio, F.; Hardies, J.; Darland, C.; Musi, N.; et al. Long-Term Pioglitazone Treatment for Patients With Nonalcoholic Steatohepatitis and Prediabetes or Type 2 Diabetes Mellitus: A Randomized Trial. Ann. Intern. Med. 2016, 165, 305-315. [CrossRef] [PubMed]

96. Belfort, R.; Berria, R.; Cornell, J.; Cusi, K. Fenofibrate reduces systemic inflammation markers independent of its effects on lipid and glucose metabolism in patients with the metabolic syndrome. J. Clin. Endocrinol. Metab. 2010, 95, 829-836. [CrossRef] [PubMed]

97. Yaghoubi, M.; Jafari, S.; Sajedi, B.; Gohari, S.; Akbarieh, S.; Heydari, A.H.; Jameshoorani, M. Comparison of fenofibrate and pioglitazone effects on patients with nonalcoholic fatty liver disease. Eur. J. Gastroenterol. Hepatol. 2017, 29, 1385-1388. [CrossRef] 
98. Fernandez-Miranda, C.; Perez-Carreras, M.; Colina, F.; Lopez-Alonso, G.; Vargas, C.; Solis-Herruzo, J.A. A pilot trial of fenofibrate for the treatment of non-alcoholic fatty liver disease. Dig. Liver Dis. 2008, 40, $200-205$. [CrossRef]

99. Corpechot, C.; Chazouilleres, O.; Rousseau, A.; Le Gruyer, A.; Habersetzer, F.; Mathurin, P.; Goria, O.; Potier, P.; Minello, A.; Silvain, C.; et al. A Placebo-Controlled Trial of Bezafibrate in Primary Biliary Cholangitis. N. Engl. J. Med. 2018, 378, 2171-2181. [CrossRef]

100. Karhapaa, P.; Uusitupa, M.; Voutilainen, E.; Laakso, M. Effects of bezafibrate on insulin sensitivity and glucose tolerance in subjects with combined hyperlipidemia. Clin. Pharm. 1992, 52, 620-626. [CrossRef]

101. Day, A.P.; Feher, M.D.; Chopra, R.; Mayne, P.D. The effect of bezafibrate treatment on serum alkaline phosphatase isoenzyme activities. Metabolism 1993, 42, 839-842. [CrossRef]

102. Armstrong, M.J.; Hull, D.; Guo, K.; Barton, D.; Hazlehurst, J.M.; Gathercole, L.L.; Nasiri, M.; Yu, J.; Gough, S.C.; Newsome, P.N.; et al. Glucagon-like peptide 1 decreases lipotoxicity in non-alcoholic steatohepatitis. J. Hepatol. 2016, 64, 399-408. [CrossRef]

103. Armstrong, M.J.; Gaunt, P.; Aithal, G.P.; Barton, D.; Hull, D.; Parker, R.; Hazlehurst, J.M.; Guo, K.; Team, L.T.; Abouda, G.; et al. Liraglutide safety and efficacy in patients with non-alcoholic steatohepatitis (LEAN): A multicentre, double-blind, randomised, placebo-controlled phase 2 study. Lancet 2016, 387, 679-690. [CrossRef]

104. Matikainen, N.; Soderlund, S.; Bjornson, E.; Pietilainen, K.; Hakkarainen, A.; Lundbom, N.; Taskinen, M.R.; Boren, J. Liraglutide treatment improves postprandial lipid metabolism and cardiometabolic risk factors in humans with adequately controlled type 2 diabetes: A single-centre randomized controlled study. Diabetesobesity Metab. 2019, 21, 84-94. [CrossRef] [PubMed]

105. Newsome, P.; Francque, S.; Harrison, S.; Ratziu, V.; Van Gaal, L.; Calanna, S.; Hansen, M.; Linder, M.; Sanyal, A. Effect of semaglutide on liver enzymes and markers of inflammation in subjects with type 2 diabetes and/or obesity. Aliment. Pharm. 2019, 50, 193-203. [CrossRef] [PubMed]

106. Cusi, K.; Sattar, N.; Garcia-Perez, L.E.; Pavo, I.; Yu, M.; Robertson, K.E.; Karanikas, C.A.; Haupt, A. Dulaglutide decreases plasma aminotransferases in people with Type 2 diabetes in a pattern consistent with liver fat reduction: A post hoc analysis of the AWARD programme. Diabet Med. 2018, 35, 1434-1439. [CrossRef] [PubMed]

107. Seko, Y.; Sumida, Y.; Tanaka, S.; Mori, K.; Taketani, H.; Ishiba, H.; Hara, T.; Okajima, A.; Umemura, A.; Nishikawa, T.; et al. Effect of 12-week dulaglutide therapy in Japanese patients with biopsy-proven non-alcoholic fatty liver disease and type 2 diabetes mellitus. Hepatol. Res. 2017, 47, 1206-1211. [CrossRef] [PubMed]

108. Bi, Y.; Zhang, B.; Xu, W.; Yang, H.; Feng, W.; Li, C.; Tong, G.; Li, M.; Wang, X.; Shen, S.; et al. Effects of exenatide, insulin, and pioglitazone on liver fat content and body fat distributions in drug-naive subjects with type 2 diabetes. Acta Diabetol. 2014, 51, 865-873. [CrossRef]

109. Shao, N.; Kuang, H.Y.; Hao, M.; Gao, X.Y.; Lin, W.J.; Zou, W. Benefits of exenatide on obesity and non-alcoholic fatty liver disease with elevated liver enzymes in patients with type 2 diabetes. Diabetes/Metab. Res. Rev. 2014, 30, 521-529. [CrossRef]

110. Klonoff, D.C.; Buse, J.B.; Nielsen, L.L.; Guan, X.; Bowlus, C.L.; Holcombe, J.H.; Wintle, M.E.; Maggs, D.G. Exenatide effects on diabetes, obesity, cardiovascular risk factors and hepatic biomarkers in patients with type 2 diabetes treated for at least 3 years. Curr. Med. Res. Opin. 2008, 24, 275-286. [CrossRef]

111. Gastaldelli, A.; Repetto, E.; Guja, C.; Hardy, E.; Han, J.; Jabbour, S.A.; Ferrannini, E. Exenatide and dapagliflozin combination improves markers of liver steatosis and fibrosis in patients with type 2 diabetes. Diabetesobesity Metab. 2020, 22, 393-403. [CrossRef]

112. Liu, L.; Yan, H.; Xia, M.; Zhao, L.; Lv, M.; Zhao, N.; Rao, S.; Yao, X.; Wu, W.; Pan, B.; et al. Efficacy of exenatide and insulin glargine on nonalcoholic fatty liver disease in patients with type 2 diabetes. Diabetes Metab. Res. Rev. 2020, e3292. [CrossRef]

113. Gluud, L.L.; Knop, F.K.; Vilsboll, T. Effects of lixisenatide on elevated liver transaminases: Systematic review with individual patient data meta-analysis of randomised controlled trials on patients with type 2 diabetes. BMJ Open 2014, 4, e005325. [CrossRef]

114. Cui, J.; Philo, L.; Nguyen, P.; Hofflich, H.; Hernandez, C.; Bettencourt, R.; Richards, L.; Salotti, J.; Bhatt, A.; Hooker, J.; et al. Sitagliptin vs. placebo for non-alcoholic fatty liver disease: A randomized controlled trial. J. Hepatol. 2016, 65, 369-376. [CrossRef] [PubMed] 
115. Watanabe, T.; Tamura, Y.; Kakehi, S.; Funayama, T.; Gastaldelli, A.; Takeno, K.; Kawaguchi, M.; Yamamoto, R.; Sato, F.; Ikeda, S.; et al. Effects of sitagliptin on ectopic fat contents and glucose metabolism in type 2 diabetic patients with fatty liver: A pilot study. J. Diabetes Investig. 2015, 6, 164-172. [CrossRef] [PubMed]

116. Joy, T.R.; McKenzie, C.A.; Tirona, R.G.; Summers, K.; Seney, S.; Chakrabarti, S.; Malhotra, N.; Beaton, M.D. Sitagliptin in patients with non-alcoholic steatohepatitis: A randomized, placebo-controlled trial. World J. Gastroenterol. 2017, 23, 141-150. [CrossRef] [PubMed]

117. Seko, Y.; Sumida, Y.; Tanaka, S.; Mori, K.; Taketani, H.; Ishiba, H.; Hara, T.; Okajima, A.; Umemura, A.; Nishikawa, T.; et al. Effect of sodium glucose cotransporter 2 inhibitor on liver function tests in Japanese patients with non-alcoholic fatty liver disease and type 2 diabetes mellitus. Hepatol. Res. 2017, 47, 1072-1078. [CrossRef]

118. Kahl, S.; Gancheva, S.; Strassburger, K.; Herder, C.; Machann, J.; Katsuyama, H.; Kabisch, S.; Henkel, E.; Kopf, S.; Lagerpusch, M.; et al. Empagliflozin Effectively Lowers Liver Fat Content in Well-Controlled Type 2 Diabetes: A Randomized, Double-Blind, Phase 4, Placebo-Controlled Trial. Diabetes Care 2020, 43, 298-305. [CrossRef]

119. Kuchay, M.S.; Krishan, S.; Mishra, S.K.; Farooqui, K.J.; Singh, M.K.; Wasir, J.S.; Bansal, B.; Kaur, P.; Jevalikar, G.; Gill, H.K.; et al. Effect of Empagliflozin on Liver Fat in Patients With Type 2 Diabetes and Nonalcoholic Fatty Liver Disease: A Randomized Controlled Trial (E-LIFT Trial). Diabetes Care 2018, 41, 1801-1808. [CrossRef]

120. Lai, L.L.; Vethakkan, S.R.; Nik Mustapha, N.R.; Mahadeva, S.; Chan, W.K. Empagliflozin for the Treatment of Nonalcoholic Steatohepatitis in Patients with Type 2 Diabetes Mellitus. Dig. Dis. Sci. 2020, 65, 623-631. [CrossRef]

121. Cusi, K.; Bril, F.; Barb, D.; Polidori, D.; Sha, S.; Ghosh, A.; Farrell, K.; Sunny, N.E.; Kalavalapalli, S.; Pettus, J.; et al. Effect of canagliflozin treatment on hepatic triglyceride content and glucose metabolism in patients with type 2 diabetes. Diabetes Obes. Metab. 2019, 21, 812-821. [CrossRef]

122. Inoue, M.; Hayashi, A.; Taguchi, T.; Arai, R.; Sasaki, S.; Takano, K.; Inoue, Y.; Shichiri, M. Effects of canagliflozin on body composition and hepatic fat content in type 2 diabetes patients with non-alcoholic fatty liver disease. J. Diabetes Investig. 2019, 10, 1004-1011. [CrossRef]

123. Itani, T.; Ishihara, T. Efficacy of canagliflozin against nonalcoholic fatty liver disease: A prospective cohort study. Obes. Sci Pr. 2018, 4, 477-482. [CrossRef]

124. Leiter, L.A.; Forst, T.; Polidori, D.; Balis, D.A.; Xie, J.; Sha, S. Effect of canagliflozin on liver function tests in patients with type 2 diabetes. Diabetes Metab. 2016, 42, 25-32. [CrossRef] [PubMed]

125. Li, B.; Wang, Y.; Ye, Z.; Yang, H.; Cui, X.; Wang, Z.; Liu, L. Effects of Canagliflozin on Fatty Liver Indexes in Patients with Type 2 Diabetes: A Meta-analysis of Randomized Controlled Trials. J. Pharm. Pharm. Sci. 2018, 21, 222-235. [CrossRef] [PubMed]

126. Seko, Y.; Nishikawa, T.; Umemura, A.; Yamaguchi, K.; Moriguchi, M.; Yasui, K.; Kimura, M.; Iijima, H.; Hashimoto, T.; Sumida, Y.; et al. Efficacy and safety of canagliflozin in type 2 diabetes mellitus patients with biopsy-proven nonalcoholic steatohepatitis classified as stage 1-3 fibrosis. Diabetes Metab. Syndr. Obes. 2018, 11, 835-843. [CrossRef] [PubMed]

127. Lee, P.C.H.; Gu, Y.; Yeung, M.Y.; Fong, C.H.Y.; Woo, Y.C.; Chow, W.S.; Tan, K.; Lam, K.S.L. Dapagliflozin and Empagliflozin Ameliorate Hepatic Dysfunction Among Chinese Subjects with Diabetes in Part Through Glycemic Improvement: A Single-Center, Retrospective, Observational Study. Diabetes 2018, 9, $285-295$. [CrossRef] [PubMed]

128. Bailey, C.J.; Gross, J.L.; Pieters, A.; Bastien, A.; List, J.F. Effect of dapagliflozin in patients with type 2 diabetes who have inadequate glycaemic control with metformin: A randomised, double-blind, placebo-controlled trial. Lancet 2010, 375, 2223-2233. [CrossRef]

129. Tobita, H.; Sato, S.; Miyake, T.; Ishihara, S.; Kinoshita, Y. Effects of Dapagliflozin on Body Composition and Liver Tests in Patients with Nonalcoholic Steatohepatitis Associated with Type 2 Diabetes Mellitus: A Prospective, Open-label, Uncontrolled Study. Curr Res. Clin. Exp. 2017, 87, 13-19. [CrossRef]

130. Eriksson, J.W.; Lundkvist, P.; Jansson, P.A.; Johansson, L.; Kvarnstrom, M.; Moris, L.; Miliotis, T.; Forsberg, G.B.; Riserus, U.; Lind, L.; et al. Effects of dapagliflozin and n-3 carboxylic acids on non-alcoholic fatty liver disease in people with type 2 diabetes: A double-blind randomised placebo-controlled study. Diabetologia 2018, 61, 1923-1934. [CrossRef] 
131. Liu, J.; Tarasenko, L.; Terra, S.G.; Huyck, S.; Wu, L.; Pong, A.; Calle, R.A.; Gallo, S.; Darekar, A.; Mancuso, J.P. Efficacy of ertugliflozin in monotherapy or combination therapy in patients with type 2 diabetes: A pooled analysis of placebo-controlled studies. Diab Vasc Dis. Res. 2019, 16, 415-423. [CrossRef]

132. Han, E.; Lee, Y.H.; Lee, B.W.; Kang, E.S.; Cha, B.S. Ipragliflozin Additively Ameliorates Non-Alcoholic Fatty Liver Disease in Patients with Type 2 Diabetes Controlled with Metformin and Pioglitazone: A 24-Week Randomized Controlled Trial. J. Clin. Med. 2020, 9, 259. [CrossRef]

133. Miyake, T.; Yoshida, S.; Furukawa, S.; Sakai, T.; Tada, F.; Senba, H.; Yamamoto, S.; Koizumi, Y.; Yoshida, O.; Hirooka, M.; et al. Ipragliflozin Ameliorates Liver Damage in Non-alcoholic Fatty Liver Disease. Open Med. 2018, 13, 402-409. [CrossRef]

134. Ohki, T.; Isogawa, A.; Toda, N.; Tagawa, K. Effectiveness of Ipragliflozin, a Sodium-Glucose Co-transporter 2 Inhibitor, as a Second-line Treatment for Non-Alcoholic Fatty Liver Disease Patients with Type 2 Diabetes Mellitus Who Do Not Respond to Incretin-Based Therapies Including Glucagon-like Peptide-1 Analogs and Dipeptidyl Peptidase-4 Inhibitors. Clin. Drug Investig. 2016, 36, 313-319. [CrossRef] [PubMed]

135. Ito, D.; Shimizu, S.; Inoue, K.; Saito, D.; Yanagisawa, M.; Inukai, K.; Akiyama, Y.; Morimoto, Y.; Noda, M.; Shimada, A. Comparison of Ipragliflozin and Pioglitazone Effects on Nonalcoholic Fatty Liver Disease in Patients With Type 2 Diabetes: A Randomized, 24-Week, Open-Label, Active-Controlled Trial. Diabetes Care 2017, 40, 1364-1372. [CrossRef] [PubMed]

136. Takase, T.; Nakamura, A.; Miyoshi, H.; Yamamoto, C.; Atsumi, T. Amelioration of fatty liver index in patients with type 2 diabetes on ipragliflozin: An association with glucose-lowering effects. Endocr. J. 2017, 64, 363-367. [CrossRef] [PubMed]

137. Ohta, A.; Kato, H.; Ishii, S.; Sasaki, Y.; Nakamura, Y.; Nakagawa, T.; Nagai, Y.; Tanaka, Y. Ipragliflozin, a sodium glucose co-transporter 2 inhibitor, reduces intrahepatic lipid content and abdominal visceral fat volume in patients with type 2 diabetes. Expert Opin. Pharmacother. 2017, 18, 1433-1438. [CrossRef]

138. Bando, Y.; Ogawa, A.; Ishikura, K.; Kanehara, H.; Hisada, A.; Notumata, K.; Okafuji, K.; Toya, D. The effects of ipragliflozin on the liver-to-spleen attenuation ratio as assessed by computed tomography and on alanine transaminase levels in Japanese patients with type 2 diabetes mellitus. Diabetol. Int. 2017, 8, 218-227. [CrossRef]

139. Ozaki, A.; Yoneda, M.; Kessoku, T.; Iwaki, M.; Kobayashi, T.; Honda, Y.; Ogawa, Y.; Imajo, K.; Sakai, E.; Taguri, M.; et al. Effect of tofogliflozin and pioglitazone on hepatic steatosis in non-alcoholic fatty liver disease patients with type 2 diabetes mellitus: A randomized, open-label pilot study (ToPiND study). Contemp. Clin. Trials Commun. 2020, 17, 100516. [CrossRef]

140. Shibuya, T.; Fushimi, N.; Kawai, M.; Yoshida, Y.; Hachiya, H.; Ito, S.; Kawai, H.; Ohashi, N.; Mori, A. Luseogliflozin improves liver fat deposition compared to metformin in type 2 diabetes patients with non-alcoholic fatty liver disease: A prospective randomized controlled pilot study. Diabetes Obes. Metab. 2018, 20, 438-442. [CrossRef]

141. Sumida, Y.; Murotani, K.; Saito, M.; Tamasawa, A.; Osonoi, Y.; Yoneda, M.; Osonoi, T. Effect of luseogliflozin on hepatic fat content in type 2 diabetes patients with non-alcoholic fatty liver disease: A prospective, single-arm trial (LEAD trial). Hepatol. Res. 2019, 49, 64-71. [CrossRef]

142. Tang, A.; Rabasa-Lhoret, R.; Castel, H.; Wartelle-Bladou, C.; Gilbert, G.; Massicotte-Tisluck, K.; Chartrand, G.; Olivie, D.; Julien, A.S.; de Guise, J.; et al. Effects of Insulin Glargine and Liraglutide Therapy on Liver Fat as Measured by Magnetic Resonance in Patients With Type 2 Diabetes: A Randomized Trial. Diabetes Care 2015, 38, 1339-1346. [CrossRef]

143. Yan, J.; Yao, B.; Kuang, H.; Yang, X.; Huang, Q.; Hong, T.; Li, Y.; Dou, J.; Yang, W.; Qin, G.; et al. Liraglutide, Sitagliptin, and Insulin Glargine Added to Metformin: The Effect on Body Weight and Intrahepatic Lipid in Patients With Type 2 Diabetes Mellitus and Nonalcoholic Fatty Liver Disease. Hepatology 2019, 69, 2414-2426. [CrossRef]

144. Buse, J.B.; Klonoff, D.C.; Nielsen, L.L.; Guan, X.; Bowlus, C.L.; Holcombe, J.H.; Maggs, D.G.; Wintle, M.E. Metabolic effects of two years of exenatide treatment on diabetes, obesity, and hepatic biomarkers in patients with type 2 diabetes: An interim analysis of data from the open-label, uncontrolled extension of three double-blind, placebo-controlled trials. Clin. Ther. 2007, 29, 139-153. [CrossRef] [PubMed]

145. Jendle, J.; Nauck, M.A.; Matthews, D.R.; Frid, A.; Hermansen, K.; During, M.; Zdravkovic, M.; Strauss, B.J.; Garber, A.J.; LEAD-2 and LEAD-3 Study Groups; et al. Weight loss with liraglutide, a once-daily human glucagon-like peptide-1 analogue for type 2 diabetes treatment as monotherapy or added to metformin, is primarily as a result of a reduction in fat tissue. Diabetesobesity Metab. 2009, 11, 1163-1172. [CrossRef] 
146. Kenny, P.R.; Brady, D.E.; Torres, D.M.; Ragozzino, L.; Chalasani, N.; Harrison, S.A. Exenatide in the treatment of diabetic patients with non-alcoholic steatohepatitis: A case series. Am. J. Gastroenterol. 2010, 105, 2707-2709. [CrossRef]

147. Sathyanarayana, P.; Jogi, M.; Muthupillai, R.; Krishnamurthy, R.; Samson, S.L.; Bajaj, M. Effects of combined exenatide and pioglitazone therapy on hepatic fat content in type 2 diabetes. Obes. Silver Spring 2011, 19, 2310-2315. [CrossRef]

148. Yilmaz, Y.; Yonal, O.; Deyneli, O.; Celikel, C.A.; Kalayci, C.; Duman, D.G. Effects of sitagliptin in diabetic patients with nonalcoholic steatohepatitis. Acta Gastro Enterol. Belg. 2012, 75, 240-244.

149. Ohki, T.; Isogawa, A.; Iwamoto, M.; Ohsugi, M.; Yoshida, H.; Toda, N.; Tagawa, K.; Omata, M.; Koike, K. The effectiveness of liraglutide in nonalcoholic fatty liver disease patients with type 2 diabetes mellitus compared to sitagliptin and pioglitazone. Sci. World J. 2012, 2012, 496453. [CrossRef] [PubMed]

150. Cuthbertson, D.J.; Irwin, A.; Gardner, C.J.; Daousi, C.; Purewal, T.; Furlong, N.; Goenka, N.; Thomas, E.L.; Adams, V.L.; Pushpakom, S.P.; et al. Improved glycaemia correlates with liver fat reduction in obese, type 2 diabetes, patients given glucagon-like peptide-1 (GLP-1) receptor agonists. PLoS ONE 2012, 7, e50117. [CrossRef]

151. Fan, H.; Pan, Q.; Xu, Y.; Yang, X. Exenatide improves type 2 diabetes concomitant with non-alcoholic fatty liver disease. Arq. Bras. De Endocrinol. E Metabol. 2013, 57, 702-708. [CrossRef]

152. Suzuki, D.; Toyoda, M.; Kimura, M.; Miyauchi, M.; Yamamoto, N.; Sato, H.; Tanaka, E.; Kuriyama, Y.; Miyatake, H.; Abe, M.; et al. Effects of liraglutide, a human glucagon-like peptide-1 analogue, on body weight, body fat area and body fat-related markers in patients with type 2 diabetes mellitus. Intern. Med. 2013, 52, 1029-1034. [CrossRef] [PubMed]

153. Bergenstal, R.M.; Li, Y.; Porter, T.K.; Weaver, C.; Han, J. Exenatide once weekly improved glycaemic control, cardiometabolic risk factors and a composite index of an $\mathrm{HbA} 1 \mathrm{c}<7 \%$, without weight gain or hypoglycaemia, over 52 weeks. Diabetes Obes. Metab. 2013, 15, 264-271. [CrossRef] [PubMed]

154. Blaslov, K.; Zibar, K.; Bulum, T.; Duvnjak, L. Effect of exenatide therapy on hepatic fat quantity and hepatic biomarkers in type 2 diabetic patients. Clin. Res. Hepatol. Gastroenterol. 2014, 38, e61-e63. [CrossRef] [PubMed]

155. Eguchi, Y.; Kitajima, Y.; Hyogo, H.; Takahashi, H.; Kojima, M.; Ono, M.; Araki, N.; Tanaka, K.; Yamaguchi, M.; Matsuda, Y.; et al. Pilot study of liraglutide effects in non-alcoholic steatohepatitis and non-alcoholic fatty liver disease with glucose intolerance in Japanese patients (LEAN-J). Hepatol. Res. 2015, 45, 269-278. [CrossRef] [PubMed]

156. Smits, M.M.; Tonneijck, L.; Muskiet, M.H.; Kramer, M.H.; Pouwels, P.J.; Pieters-van den Bos, I.C.; Hoekstra, T.; Diamant, M.; van Raalte, D.H.; Cahen, D.L. Twelve week liraglutide or sitagliptin does not affect hepatic fat in type 2 diabetes: A randomised placebo-controlled trial. Diabetologia 2016, 59, 2588-2593. [CrossRef] [PubMed]

157. Petit, J.M.; Cercueil, J.P.; Loffroy, R.; Denimal, D.; Bouillet, B.; Fourmont, C.; Chevallier, O.; Duvillard, L.; Verges, B. Effect of Liraglutide Therapy on Liver Fat Content in Patients with Inadequately Controlled Type 2 Diabetes: The Lira-NAFLD Study. J. Clin. Endocrinol. Metab. 2017, 102, 407-415. [CrossRef]

158. Feng, W.; Gao, C.; Bi, Y.; Wu, M.; Li, P.; Shen, S.; Chen, W.; Yin, T.; Zhu, D. Randomized trial comparing the effects of gliclazide, liraglutide, and metformin on diabetes with non-alcoholic fatty liver disease. J. Diabetes 2017, 9, 800-809. [CrossRef]

159. Khoo, J.; Hsiang, J.; Taneja, R.; Law, N.M.; Ang, T.L. Comparative effects of liraglutide 3 mg vs structured lifestyle modification on body weight, liver fat and liver function in obese patients with non-alcoholic fatty liver disease: A pilot randomized trial. Diabetesobesity Metab. 2017, 19, 1814-1817. [CrossRef]

160. Ding, X.; Saxena, N.K.; Lin, S.; Gupta, N.A.; Anania, F.A. Exendin-4, a glucagon-like protein-1 (GLP-1) receptor agonist, reverses hepatic steatosis in ob/ob mice. Hepatology 2006, 43, 173-181. [CrossRef]

161. Samson, S.L.; Gonzalez, E.V.; Yechoor, V.; Bajaj, M.; Oka, K.; Chan, L. Gene therapy for diabetes: Metabolic effects of helper-dependent adenoviral exendin 4 expression in a diet-induced obesity mouse model. Mol. Ther. 2008, 16, 1805-1812. [CrossRef]

162. Samson, S.L.; Sathyanarayana, P.; Jogi, M.; Gonzalez, E.V.; Gutierrez, A.; Krishnamurthy, R.; Muthupillai, R.; Chan, L.; Bajaj, M. Exenatide decreases hepatic fibroblast growth factor 21 resistance in non-alcoholic fatty liver disease in a mouse model of obesity and in a randomised controlled trial. Diabetologia 2011, 54, 3093-3100. [CrossRef] 
163. Sharma, S.; Mells, J.E.; Fu, P.P.; Saxena, N.K.; Anania, F.A. GLP-1 analogs reduce hepatocyte steatosis and improve survival by enhancing the unfolded protein response and promoting macroautophagy. PLoS ONE 2011, 6, e25269. [CrossRef]

164. Armstrong, M.J.; Houlihan, D.D.; Rowe, I.A.; Clausen, W.H.; Elbrond, B.; Gough, S.C.; Tomlinson, J.W.; Newsome, P.N. Safety and efficacy of liraglutide in patients with type 2 diabetes and elevated liver enzymes: Individual patient data meta-analysis of the LEAD program. Aliment. Pharmacol. Ther. 2013, 37, $234-242$. [CrossRef] [PubMed]

165. Trevaskis, J.L.; Griffin, P.S.; Wittmer, C.; Neuschwander-Tetri, B.A.; Brunt, E.M.; Dolman, C.S.; Erickson, M.R.; Napora, J.; Parkes, D.G.; Roth, J.D. Glucagon-like peptide-1 receptor agonism improves metabolic, biochemical, and histopathological indices of nonalcoholic steatohepatitis in mice. Am. J. Physiol. 2012, 302, G762-G772. [CrossRef] [PubMed]

166. Dong, Y.; Lv, Q.; Li, S.; Wu, Y.; Li, L.; Li, J.; Zhang, F.; Sun, X.; Tong, N. Efficacy and safety of glucagon-like peptide-1 receptor agonists in non-alcoholic fatty liver disease: A systematic review and meta-analysis. Clin. Res. Hepatol. Gastroenterol. 2017, 41, 284-295. [CrossRef] [PubMed]

167. Prigeon, R.L.; Quddusi, S.; Paty, B.; D'Alessio, D.A. Suppression of glucose production by GLP-1 independent of islet hormones: A novel extrapancreatic effect. Am. J. Physiol. Endocrinol. Metab. 2003, 285, E701-E707. [CrossRef] [PubMed]

168. Seghieri, M.; Rebelos, E.; Gastaldelli, A.; Astiarraga, B.D.; Casolaro, A.; Barsotti, E.; Pocai, A.; Nauck, M.; Muscelli, E.; Ferrannini, E. Direct effect of GLP-1 infusion on endogenous glucose production in humans. Diabetologia 2013, 56, 156-161. [CrossRef] [PubMed]

169. Gupta, N.A.; Kolachala, V.L.; Jiang, R.; Abramowsky, C.; Romero, R.; Fifadara, N.; Anania, F.; Knechtle, S.; Kirk, A. The glucagon-like peptide-1 receptor agonist Exendin 4 has a protective role in ischemic injury of lean and steatotic liver by inhibiting cell death and stimulating lipolysis. Am. J. Pathol. 2012, 181, 1693-1701. [CrossRef]

170. Svegliati-Baroni, G.; Saccomanno, S.; Rychlicki, C.; Agostinelli, L.; De Minicis, S.; Candelaresi, C.; Faraci, G.; Pacetti, D.; Vivarelli, M.; Nicolini, D.; et al. Glucagon-like peptide-1 receptor activation stimulates hepatic lipid oxidation and restores hepatic signalling alteration induced by a high-fat diet in nonalcoholic steatohepatitis. Liver Int. Off. J. Int. Assoc. Study Liver 2011, 31, 1285-1297. [CrossRef]

171. Cersosimo, E.; Gastaldelli, A.; Cervera, A.; Wajcberg, E.; Sriwijilkamol, A.; Fernandez, M.; Zuo, P.; Petz, R.; Triplitt, C.; Musi, N.; et al. Effect of exenatide on splanchnic and peripheral glucose metabolism in type 2 diabetic subjects. J. Clin. Endocrinol. Metab. 2011, 96, 1763-1770. [CrossRef]

172. Vahl, T.P.; Tauchi, M.; Durler, T.S.; Elfers, E.E.; Fernandes, T.M.; Bitner, R.D.; Ellis, K.S.; Woods, S.C.; Seeley, R.J.; Herman, J.P.; et al. Glucagon-like peptide-1 (GLP-1) receptors expressed on nerve terminals in the portal vein mediate the effects of endogenous GLP-1 on glucose tolerance in rats. Endocrinology 2007, 148, 4965-4973. [CrossRef]

173. Pyke, C.; Heller, R.S.; Kirk, R.K.; Orskov, C.; Reedtz-Runge, S.; Kaastrup, P.; Hvelplund, A.; Bardram, L.; Calatayud, D.; Knudsen, L.B. GLP-1 receptor localization in monkey and human tissue: Novel distribution revealed with extensively validated monoclonal antibody. Endocrinology 2014, 155, 1280-1290. [CrossRef]

174. Wei, Y.; Mojsov, S. Tissue-specific expression of the human receptor for glucagon-like peptide-I: Brain, heart and pancreatic forms have the same deduced amino acid sequences. Febs Lett. 1995, 358, $219-224$. [CrossRef]

175. Seo, D.; Faintuch, B.L.; Aparecida de Oliveira, E.; Faintuch, J. Pancreas and liver uptake of new radiolabeled incretins (GLP-1 and Exendin-4) in models of diet-induced and diet-restricted obesity. Nucl. Med. Biol. 2017, 49, 57-64. [CrossRef] [PubMed]

176. DeFronzo, R.A.; Okerson, T.; Viswanathan, P.; Guan, X.; Holcombe, J.H.; MacConell, L. Effects of exenatide versus sitagliptin on postprandial glucose, insulin and glucagon secretion, gastric emptying, and caloric intake: A randomized, cross-over study. Curr. Med. Res. Opin. 2008, 24, 2943-2952. [CrossRef] [PubMed]

177. Matikainen, N.; Manttari, S.; Schweizer, A.; Ulvestad, A.; Mills, D.; Dunning, B.E.; Foley, J.E.; Taskinen, M.R. Vildagliptin therapy reduces postprandial intestinal triglyceride-rich lipoprotein particles in patients with type 2 diabetes. Diabetologia 2006, 49, 2049-2057. [CrossRef] [PubMed]

178. Camastra, S.; Astiarraga, B.; Tura, A.; Frascerra, S.; Ciociaro, D.; Mari, A.; Gastaldelli, A.; Ferrannini, E. Effect of exenatide on postprandial glucose fluxes, lipolysis, and ss-cell function in non-diabetic, morbidly obese patients. Diabetes Obes. Metab. 2017, 19, 412-420. [CrossRef] 
179. Ben-Shlomo, S.; Zvibel, I.; Shnell, M.; Shlomai, A.; Chepurko, E.; Halpern, Z.; Barzilai, N.; Oren, R.; Fishman, S. Glucagon-like peptide-1 reduces hepatic lipogenesis via activation of AMP-activated protein kinase. J. Hepatol. 2011, 54, 1214-1223. [CrossRef]

180. Parlevliet, E.T.; Wang, Y.; Geerling, J.J.; Schroder-Van der Elst, J.P.; Picha, K.; O’Neil, K.; Stojanovic-Susulic, V.; Ort, T.; Havekes, L.M.; Romijn, J.A.; et al. GLP-1 receptor activation inhibits VLDL production and reverses hepatic steatosis by decreasing hepatic lipogenesis in high-fat-fed APOE*3-Leiden mice. PLoS ONE 2012, 7, e49152. [CrossRef]

181. Gupta, N.A.; Mells, J.; Dunham, R.M.; Grakoui, A.; Handy, J.; Saxena, N.K.; Anania, F.A. Glucagon-like peptide-1 receptor is present on human hepatocytes and has a direct role in decreasing hepatic steatosis in vitro by modulating elements of the insulin signaling pathway. Hepatology 2010, 51, 1584-1592. [CrossRef]

182. Lee, Y.S.; Park, M.S.; Choung, J.S.; Kim, S.S.; Oh, H.H.; Choi, C.S.; Ha, S.Y.; Kang, Y.; Kim, Y.; Jun, H.S. Glucagon-like peptide-1 inhibits adipose tissue macrophage infiltration and inflammation in an obese mouse model of diabetes. Diabetologia 2012, 55, 2456-2468. [CrossRef]

183. Shirakawa, J.; Fujii, H.; Ohnuma, K.; Sato, K.; Ito, Y.; Kaji, M.; Sakamoto, E.; Koganei, M.; Sasaki, H.; Nagashima, Y.; et al. Diet-induced adipose tissue inflammation and liver steatosis are prevented by DPP-4 inhibition in diabetic mice. Diabetes 2011, 60, 1246-1257. [CrossRef]

184. Zhang, L.; Yang, M.; Ren, H.; Hu, H.; Boden, G.; Li, L.; Yang, G. GLP-1 analogue prevents NAFLD in ApoE KO mice with diet and Acrp30 knockdown by inhibiting c-JNK. Liver Int. Off. J. Int. Assoc. Study Liver 2013, 33, 794-804. [CrossRef] [PubMed]

185. Schwartz, E.A.; Koska, J.; Mullin, M.P.; Syoufi, I.; Schwenke, D.C.; Reaven, P.D. Exenatide suppresses postprandial elevations in lipids and lipoproteins in individuals with impaired glucose tolerance and recent onset type 2 diabetes mellitus. Atherosclerosis 2010, 212, 217-222. [CrossRef] [PubMed]

186. Hermansen, K.; Baekdal, T.A.; During, M.; Pietraszek, A.; Mortensen, L.S.; Jorgensen, H.; Flint, A. Liraglutide suppresses postprandial triglyceride and apolipoprotein B48 elevations after a fat-rich meal in patients with type 2 diabetes: A randomized, double-blind, placebo-controlled, cross-over trial. Diabetesobesity Metab. 2013, 15, 1040-1048. [CrossRef] [PubMed]

187. Whyte, M.B.; Shojaee-Moradie, F.; Sharaf, S.E.; Jackson, N.C.; Fielding, B.; Hovorka, R.; Mendis, J.; Russell-Jones, D.; Umpleby, A.M. Lixisenatide Reduces Chylomicron Triacylglycerol by Increased Clearance. J. Clin. Endocrinol. Metab. 2019, 104, 359-368. [CrossRef] [PubMed]

188. Miyazaki, M.; Kato, M.; Tanaka, K.; Tanaka, M.; Kohjima, M.; Nakamura, K.; Enjoji, M.; Nakamuta, M.; Kotoh, K.; Takayanagi, R. Increased hepatic expression of dipeptidyl peptidase-4 in non-alcoholic fatty liver disease and its association with insulin resistance and glucose metabolism. Mol. Med. Rep. 2012, 5, 729-733. [CrossRef]

189. Firneisz, G.; Varga, T.; Lengyel, G.; Feher, J.; Ghyczy, D.; Wichmann, B.; Selmeci, L.; Tulassay, Z.; Racz, K.; Somogyi, A. Serum dipeptidyl peptidase-4 activity in insulin resistant patients with non-alcoholic fatty liver disease: A novel liver disease biomarker. PLOS ONE 2010, 5, e12226. [CrossRef]

190. Balaban, Y.H.; Korkusuz, P.; Simsek, H.; Gokcan, H.; Gedikoglu, G.; Pinar, A.; Hascelik, G.; Asan, E.; Hamaloglu, E.; Tatar, G. Dipeptidyl peptidase IV (DDP IV) in NASH patients. Ann. Hepatol. 2007, 6, 242-250. [CrossRef]

191. Olivares, M.; Schuppel, V.; Hassan, A.M.; Beaumont, M.; Neyrinck, A.M.; Bindels, L.B.; Benitez-Paez, A.; Sanz, Y.; Haller, D.; Holzer, P.; et al. The Potential Role of the Dipeptidyl Peptidase-4-Like Activity From the Gut Microbiota on the Host Health. Front. Microbiol. 2018, 9, 1900. [CrossRef]

192. Mulvihill, E.E.; Varin, E.M.; Gladanac, B.; Campbell, J.E.; Ussher, J.R.; Baggio, L.L.; Yusta, B.; Ayala, J.; Burmeister, M.A.; Matthews, D.; et al. Cellular Sites and Mechanisms Linking Reduction of Dipeptidyl Peptidase-4 Activity to Control of Incretin Hormone Action and Glucose Homeostasis. Cell Metab. 2017, 25, 152-165. [CrossRef]

193. Sanchez-Garrido, M.A.; Brandt, S.J.; Clemmensen, C.; Muller, T.D.; DiMarchi, R.D.; Tschop, M.H. GLP-1/glucagon receptor co-agonism for treatment of obesity. Diabetologia 2017, 60, 1851-1861. [CrossRef]

194. Seghieri, M.; Christensen, A.S.; Andersen, A.; Solini, A.; Knop, F.K.; Vilsboll, T. Future Perspectives on GLP-1 Receptor Agonists and GLP-1/glucagon Receptor Co-agonists in the Treatment of NAFLD. Front. Endocrinology 2018, 9, 649. [CrossRef] [PubMed]

195. Brandt, S.J.; Muller, T.D.; DiMarchi, R.D.; Tschop, M.H.; Stemmer, K. Peptide-based multi-agonists: A new paradigm in metabolic pharmacology. J. Intern. Med. 2018, 284, 581-602. [CrossRef] [PubMed] 
196. Asmar, M.; Simonsen, L.; Madsbad, S.; Stallknecht, B.; Holst, J.J.; Bulow, J. Glucose-dependent insulinotropic polypeptide may enhance fatty acid re-esterification in subcutaneous abdominal adipose tissue in lean humans. Diabetes 2010, 59, 2160-2163. [CrossRef] [PubMed]

197. Carlson, M.G.; Snead, W.L.; Campbell, P.J. Regulation of free fatty acid metabolism by glucagon. J. Clin. Endocrinol. Metab. 1993, 77, 11-15. [CrossRef] [PubMed]

198. Gerich, J.E.; Lorenzi, M.; Bier, D.M.; Tsalikian, E.; Schneider, V.; Karam, J.H.; Forsham, P.H. Effects of physiologic levels of glucagon and growth hormone on human carbohydrate and lipid metabolism. Studies involving administration of exogenous hormone during suppression of endogenous hormone secretion with somatostatin. J. Clin. Investig. 1976, 57, 875-884. [CrossRef]

199. Tillner, J.; Posch, M.G.; Wagner, F.; Teichert, L.; Hijazi, Y.; Einig, C.; Keil, S.; Haack, T.; Wagner, M.; Bossart, M.; et al. A novel dual glucagon-like peptide and glucagon receptor agonist SAR425899: Results of randomized, placebo-controlled first-in-human and first-in-patient trials. Diabetesobesity Amp Metab. 2019, 21, 120-128. [CrossRef]

200. You, S.; Mcdonald, M.; Case, M.; Steiner, D.; Tat, T.; Jenkinson, C.; Pick, R.; Hart, J.; Moreno, V.; Parise, J.; et al. Long-Acting GLP-1 and Glucagon Receptor Dual Agonists for the Treatment of Type 2 Diabetes. Diabetes 2016, 65 (Suppl. 1), A221-A360. [CrossRef]

201. Hershkovitz, O.; Bar-IIan, A.; Hart, G.; Fima, E. The long-acting dual GLP-1/Glucagon Agonist, MOD-6030 improves glycaemic control and induces a prolonged weight loss in diet induced obesity mice following a once weekly administration. In Proceedings of the Endocrine Society's 95th Annual Meeting and Expo, San Francisco, CA, USA, 15-18 June 2013.

202. Day, J.W.; Ottaway, N.; Patterson, J.T.; Gelfanov, V.; Smiley, D.; Gidda, J.; Findeisen, H.; Bruemmer, D.; Drucker, D.J.; Chaudhary, N.; et al. A new glucagon and GLP-1 co-agonist eliminates obesity in rodents. Nat. Chem. Biol. 2009, 5, 749-757. [CrossRef]

203. Day, J.W.; Gelfanov, V.; Smiley, D.; Carrington, P.E.; Eiermann, G.; Chicchi, G.; Erion, M.D.; Gidda, J.; Thornberry, N.A.; Tschop, M.H.; et al. Optimization of co-agonism at GLP-1 and glucagon receptors to safely maximize weight reduction in DIO-rodents. Biopolymers 2012, 98, 443-450. [CrossRef]

204. Pocai, A.; Carrington, P.E.; Adams, J.R.; Wright, M.; Eiermann, G.; Zhu, L.; Du, X.; Petrov, A.; Lassman, M.E.; Jiang, G.; et al. Glucagon-like peptide 1/glucagon receptor dual agonism reverses obesity in mice. Diabetes 2009, 58, 2258-2266. [CrossRef]

205. Valdecantos, M.P.; Pardo, V.; Ruiz, L.; Castro-Sanchez, L.; Lanzon, B.; Fernandez-Millan, E.; Garcia-Monzon, C.; Arroba, A.I.; Gonzalez-Rodriguez, A.; Escriva, F.; et al. A novel glucagon-like peptide 1/glucagon receptor dual agonist improves steatohepatitis and liver regeneration in mice. Hepatology 2017, 65, 950-968. [CrossRef]

206. Clemmensen, C.; Chabenne, J.; Finan, B.; Sullivan, L.; Fischer, K.; Kuchler, D.; Sehrer, L.; Ograjsek, T.; Hofmann, S.M.; Schriever, S.C.; et al. GLP-1/glucagon coagonism restores leptin responsiveness in obese mice chronically maintained on an obesogenic diet. Diabetes 2014, 63, 1422-1427. [CrossRef]

207. Patel, V.; Joharapurkar, A.; Kshirsagar, S.; Sutariya, B.; Patel, M.; Patel, H.; Pandey, D.; Patel, D.; Ranvir, R.; Kadam, S.; et al. Coagonist of GLP-1 and Glucagon Receptor Ameliorates Development of Non-Alcoholic Fatty Liver Disease. Cardiovasc. Hematol. Agents Med. Chem. 2018, 16, 35-43. [CrossRef]

208. Henderson, S.J.; Konkar, A.; Hornigold, D.C.; Trevaskis, J.L.; Jackson, R.; Fritsch Fredin, M.; Jansson-Lofmark, R.; Naylor, J.; Rossi, A.; Bednarek, M.A.; et al. Robust anti-obesity and metabolic effects of a dual GLP-1/glucagon receptor peptide agonist in rodents and non-human primates. Diabetesobesity Metab. 2016, 18, 1176-1190. [CrossRef]

209. Schmitt, C.; Portron, A.; Jadidi, S.; Sarkar, N.; DiMarchi, R. Pharmacodynamics, pharmacokinetics and safety of multiple ascending doses of the novel dual glucose-dependent insulinotropic polypeptide/glucagon-like peptide-1 agonist RG7697 in people with type 2 diabetes mellitus. Diabetesobesity Metab. 2017, 19, 1436-1445. [CrossRef]

210. Finan, B.; Yang, B.; Ottaway, N.; Smiley, D.L.; Ma, T.; Clemmensen, C.; Chabenne, J.; Zhang, L.; Habegger, K.M.; Fischer, K.; et al. A rationally designed monomeric peptide triagonist corrects obesity and diabetes in rodents. Nat. Med. 2015, 21, 27-36. [CrossRef]

211. Jall, S.; Sachs, S.; Clemmensen, C.; Finan, B.; Neff, F.; DiMarchi, R.D.; Tschop, M.H.; Muller, T.D.; Hofmann, S.M. Monomeric GLP-1/GIP/glucagon triagonism corrects obesity, hepatosteatosis, and dyslipidemia in female mice. Mol. Metab. 2017, 6, 440-446. [CrossRef] 
212. Nicholson, J.K.; Holmes, E.; Kinross, J.; Burcelin, R.; Gibson, G.; Jia, W.; Pettersson, S. Host-gut microbiota metabolic interactions. Science 2012, 336, 1262-1267. [CrossRef]

213. Jia, W.; Xie, G.; Jia, W. Bile acid-microbiota crosstalk in gastrointestinal inflammation and carcinogenesis. Nat. Rev. Gastroenterol. Hepatol. 2018, 15, 111-128. [CrossRef]

214. Flint, H.J.; Scott, K.P.; Louis, P.; Duncan, S.H. The role of the gut microbiota in nutrition and health. Nat. Rev. Gastroenterol. Hepatol. 2012, 9, 577-589. [CrossRef]

215. Donaldson, G.P.; Lee, S.M.; Mazmanian, S.K. Gut biogeography of the bacterial microbiota. Nat. Rev. Microbiol. 2016, 14, 20-32. [CrossRef] [PubMed]

216. Human Microbiome Project, C. Structure, function and diversity of the healthy human microbiome. Nature 2012, 486, 207-214. [CrossRef] [PubMed]

217. Neish, A.S. Microbes in gastrointestinal health and disease. Gastroenterology 2009, 136, 65-80. [CrossRef] [PubMed]

218. Sommer, F.; Backhed, F. The gut microbiota-masters of host development and physiology. Nat. Rev. Microbiol. 2013, 11, 227-238. [CrossRef] [PubMed]

219. Turnbaugh, P.J.; Ley, R.E.; Mahowald, M.A.; Magrini, V.; Mardis, E.R.; Gordon, J.I. An obesity-associated gut microbiome with increased capacity for energy harvest. Nature 2006, 444, 1027-1031. [CrossRef]

220. Leclercq, S.; Matamoros, S.; Cani, P.D.; Neyrinck, A.M.; Jamar, F.; Starkel, P.; Windey, K.; Tremaroli, V.; Backhed, F.; Verbeke, K.; et al. Intestinal permeability, gut-bacterial dysbiosis, and behavioral markers of alcohol-dependence severity. Proc. Natl. Acad. Sci. USA 2014, 111, E4485-E4493. [CrossRef]

221. Bajaj, J.S.; Idilman, R.; Mabudian, L.; Hood, M.; Fagan, A.; Turan, D.; White, M.B.; Karakaya, F.; Wang, J.; Atalay, R.; et al. Diet affects gut microbiota and modulates hospitalization risk differentially in an international cirrhosis cohort. Hepatology 2018, 68, 234-247. [CrossRef]

222. Davis, B.C.; Bajaj, J.S. The Human Gut Microbiome in Liver Diseases. Semin. Liver Dis. 2017, 37, 128-140. [CrossRef]

223. Llorente, C.; Jepsen, P.; Inamine, T.; Wang, L.; Bluemel, S.; Wang, H.J.; Loomba, R.; Bajaj, J.S.; Schubert, M.L.; Sikaroodi, M.; et al. Gastric acid suppression promotes alcoholic liver disease by inducing overgrowth of intestinal Enterococcus. Nat. Commun. 2017, 8, 837. [CrossRef]

224. Mouzaki, M.; Comelli, E.M.; Arendt, B.M.; Bonengel, J.; Fung, S.K.; Fischer, S.E.; McGilvray, I.D.; Allard, J.P. Intestinal microbiota in patients with nonalcoholic fatty liver disease. Hepatology 2013, 58, 120-127. [CrossRef]

225. Zhu, L.; Baker, S.S.; Gill, C.; Liu, W.; Alkhouri, R.; Baker, R.D.; Gill, S.R. Characterization of gut microbiomes in nonalcoholic steatohepatitis (NASH) patients: A connection between endogenous alcohol and NASH. Hepatology 2013, 57, 601-609. [CrossRef] [PubMed]

226. Henao-Mejia, J.; Elinav, E.; Jin, C.; Hao, L.; Mehal, W.Z.; Strowig, T.; Thaiss, C.A.; Kau, A.L.; Eisenbarth, S.C.; Jurczak, M.J.; et al. Inflammasome-mediated dysbiosis regulates progression of NAFLD and obesity. Nature 2012, 482, 179-185. [CrossRef] [PubMed]

227. Pierantonelli, I.; Rychlicki, C.; Agostinelli, L.; Giordano, D.M.; Gaggini, M.; Fraumene, C.; Saponaro, C.; Manghina, V.; Sartini, L.; Mingarelli, E.; et al. Lack of NLRP3-inflammasome leads to gut-liver axis derangement, gut dysbiosis and a worsened phenotype in a mouse model of NAFLD. Sci. Rep. 2017, 7, 12200. [CrossRef] [PubMed]

228. De Minicis, S.; Rychlicki, C.; Agostinelli, L.; Saccomanno, S.; Candelaresi, C.; Trozzi, L.; Mingarelli, E.; Facinelli, B.; Magi, G.; Palmieri, C.; et al. Dysbiosis contributes to fibrogenesis in the course of chronic liver injury in mice. Hepatology 2014, 59, 1738-1749. [CrossRef]

229. Ponziani, F.R.; Bhoori, S.; Castelli, C.; Putignani, L.; Rivoltini, L.; Del Chierico, F.; Sanguinetti, M.; Morelli, D.; Paroni Sterbini, F.; Petito, V.; et al. Hepatocellular Carcinoma Is Associated With Gut Microbiota Profile and Inflammation in Nonalcoholic Fatty Liver Disease. Hepatology 2019, 69, 107-120. [CrossRef]

230. Boursier, J.; Mueller, O.; Barret, M.; Machado, M.; Fizanne, L.; Araujo-Perez, F.; Guy, C.D.; Seed, P.C.; Rawls, J.F.; David, L.A.; et al. The severity of nonalcoholic fatty liver disease is associated with gut dysbiosis and shift in the metabolic function of the gut microbiota. Hepatology 2016, 63, 764-775. [CrossRef]

231. Del Chierico, F.; Nobili, V.; Vernocchi, P.; Russo, A.; De Stefanis, C.; Gnani, D.; Furlanello, C.; Zandona, A.; Paci, P.; Capuani, G.; et al. Gut microbiota profiling of pediatric nonalcoholic fatty liver disease and obese patients unveiled by an integrated meta-omics-based approach. Hepatology 2017, 65, 451-464. [CrossRef] 
232. Loomba, R.; Seguritan, V.; Li, W.; Long, T.; Klitgord, N.; Bhatt, A.; Dulai, P.S.; Caussy, C.; Bettencourt, R.; Highlander, S.K.; et al. Gut Microbiome-Based Metagenomic Signature for Non-invasive Detection of Advanced Fibrosis in Human Nonalcoholic Fatty Liver Disease. Cell Metab. 2017, 25, 1054-1062.e5. [CrossRef]

233. Hoyles, L.; Fernandez-Real, J.M.; Federici, M.; Serino, M.; Abbott, J.; Charpentier, J.; Heymes, C.; Luque, J.L.; Anthony, E.; Barton, R.H.; et al. Molecular phenomics and metagenomics of hepatic steatosis in non-diabetic obese women. Nat. Med. 2018, 24, 1070-1080. [CrossRef]

234. Leung, C.; Rivera, L.; Furness, J.B.; Angus, P.W. The role of the gut microbiota in NAFLD. Nat. Rev. Gastroenterol. Hepatol. 2016, 13, 412-425. [CrossRef]

235. den Besten, G.; van Eunen, K.; Groen, A.K.; Venema, K.; Reijngoud, D.J.; Bakker, B.M. The role of short-chain fatty acids in the interplay between diet, gut microbiota, and host energy metabolism. J. Lipid Res. 2013, 54, 2325-2340. [CrossRef] [PubMed]

236. Chu, H.; Duan, Y.; Yang, L.; Schnabl, B. Small metabolites, possible big changes: A microbiota-centered view of non-alcoholic fatty liver disease. Gut 2019, 68, 359-370. [CrossRef] [PubMed]

237. Tolhurst, G.; Heffron, H.; Lam, Y.S.; Parker, H.E.; Habib, A.M.; Diakogiannaki, E.; Cameron, J.; Grosse, J.; Reimann, F.; Gribble, F.M. Short-chain fatty acids stimulate glucagon-like peptide-1 secretion via the G-protein-coupled receptor FFAR2. Diabetes 2012, 61, 364-371. [CrossRef] [PubMed]

238. Bashiardes, S.; Shapiro, H.; Rozin, S.; Shibolet, O.; Elinav, E. Non-alcoholic fatty liver and the gut microbiota. Mol. Metab. 2016, 5, 782-794. [CrossRef]

239. Cani, P.D. Human gut microbiome: Hopes, threats and promises. Gut 2018, 67, 1716-1725. [CrossRef]

240. Marra, F.; Svegliati-Baroni, G. Lipotoxicity and the gut-liver axis in NASH pathogenesis. J. Hepatol. 2018, 68, 280-295. [CrossRef]

241. Sandler, N.G.; Koh, C.; Roque, A.; Eccleston, J.L.; Siegel, R.B.; Demino, M.; Kleiner, D.E.; Deeks, S.G.; Liang, T.J.; Heller, T.; et al. Host response to translocated microbial products predicts outcomes of patients with HBV or HCV infection. Gastroenterology 2011, 141, 1220-1230.e3. [CrossRef]

242. Arab, J.P.; Karpen, S.J.; Dawson, P.A.; Arrese, M.; Trauner, M. Bile acids and nonalcoholic fatty liver disease: Molecular insights and therapeutic perspectives. Hepatology 2017, 65, 350-362. [CrossRef]

243. Thomas, C.; Pellicciari, R.; Pruzanski, M.; Auwerx, J.; Schoonjans, K. Targeting bile-acid signalling for metabolic diseases. Nat. Rev. Drug Discov. 2008, 7, 678-693. [CrossRef]

244. Trauner, M.; Fuchs, C.D.; Halilbasic, E.; Paumgartner, G. New therapeutic concepts in bile acid transport and signaling for management of cholestasis. Hepatology 2017, 65, 1393-1404. [CrossRef]

245. Yoshimoto, S.; Loo, T.M.; Atarashi, K.; Kanda, H.; Sato, S.; Oyadomari, S.; Iwakura, Y.; Oshima, K.; Morita, H.; Hattori, M.; et al. Obesity-induced gut microbial metabolite promotes liver cancer through senescence secretome. Nature 2013, 499, 97-101. [CrossRef] [PubMed]

246. David, L.A.; Maurice, C.F.; Carmody, R.N.; Gootenberg, D.B.; Button, J.E.; Wolfe, B.E.; Ling, A.V.; Devlin, A.S.; Varma, Y.; Fischbach, M.A.; et al. Diet rapidly and reproducibly alters the human gut microbiome. Nature 2014, 505, 559-563. [CrossRef] [PubMed]

247. Puri, P.; Daita, K.; Joyce, A.; Mirshahi, F.; Santhekadur, P.K.; Cazanave, S.; Luketic, V.A.; Siddiqui, M.S.; Boyett, S.; Min, H.K.; et al. The presence and severity of nonalcoholic steatohepatitis is associated with specific changes in circulating bile acids. Hepatology 2018, 67, 534-548. [CrossRef] [PubMed]

248. Xie, G.; Wang, X.; Huang, F.; Zhao, A.; Chen, W.; Yan, J.; Zhang, Y.; Lei, S.; Ge, K.; Zheng, X.; et al. Dysregulated hepatic bile acids collaboratively promote liver carcinogenesis. Int. J. Cancer 2016, 139, 1764-1775. [CrossRef]

249. Xie, G.; Wang, X.; Liu, P.; Wei, R.; Chen, W.; Rajani, C.; Hernandez, B.Y.; Alegado, R.; Dong, B.; Li, D.; et al. Distinctly altered gut microbiota in the progression of liver disease. Oncotarget 2016, 7, 19355-19366. [CrossRef]

250. Fuchs, C.D.; Traussnigg, S.A.; Trauner, M. Nuclear Receptor Modulation for the Treatment of Nonalcoholic Fatty Liver Disease. Semin. Liver Dis. 2016, 36, 69-86. [CrossRef]

251. Fickert, P.; Fuchsbichler, A.; Moustafa, T.; Wagner, M.; Zollner, G.; Halilbasic, E.; Stoger, U.; Arrese, M.; Pizarro, M.; Solis, N.; et al. Farnesoid X receptor critically determines the fibrotic response in mice but is expressed to a low extent in human hepatic stellate cells and periductal myofibroblasts. Am. J. Pathol. 2009, 175, 2392-2405. [CrossRef]

252. Intercept Pharmaceuticals. Intercept Receives Complete Response Letter from FDA for Obeticholic Acid for the Treatment of Fibrosis Due to NASH; Intercept Pharmaceuticals: New York, NY, USA, 2020. 
253. Yang, F.; Huang, X.; Yi, T.; Yen, Y.; Moore, D.D.; Huang, W. Spontaneous development of liver tumors in the absence of the bile acid receptor farnesoid X receptor. Cancer Res. 2007, 67, 863-867. [CrossRef]

254. Degirolamo, C.; Modica, S.; Vacca, M.; Di Tullio, G.; Morgano, A.; D’Orazio, A.; Kannisto, K.; Parini, P.; Moschetta, A. Prevention of spontaneous hepatocarcinogenesis in farnesoid $\mathrm{X}$ receptor-null mice by intestinal-specific farnesoid $X$ receptor reactivation. Hepatology 2015, 61, 161-170. [CrossRef]

255. Fang, S.; Suh, J.M.; Reilly, S.M.; Yu, E.; Osborn, O.; Lackey, D.; Yoshihara, E.; Perino, A.; Jacinto, S.; Lukasheva, Y.; et al. Intestinal FXR agonism promotes adipose tissue browning and reduces obesity and insulin resistance. Nat. Med. 2015, 21, 159-165. [CrossRef]

256. Jiang, C.; Xie, C.; Lv, Y.; Li, J.; Krausz, K.W.; Shi, J.; Brocker, C.N.; Desai, D.; Amin, S.G.; Bisson, W.H.; et al. Intestine-selective farnesoid $\mathrm{X}$ receptor inhibition improves obesity-related metabolic dysfunction. Nat. Commun. 2015, 6, 10166. [CrossRef] [PubMed]

257. Jiang, C.; Xie, C.; Li, F.; Zhang, L.; Nichols, R.G.; Krausz, K.W.; Cai, J.; Qi, Y.; Fang, Z.Z.; Takahashi, S.; et al. Intestinal farnesoid $X$ receptor signaling promotes nonalcoholic fatty liver disease. J. Clin. Investig. 2015, 125, 386-402. [CrossRef] [PubMed]

258. Kliewer, S.A.; Mangelsdorf, D.J. Bile Acids as Hormones: The FXR-FGF15/19 Pathway. Dig. Dis. 2015, 33, 327-331. [CrossRef] [PubMed]

259. Nicholes, K.; Guillet, S.; Tomlinson, E.; Hillan, K.; Wright, B.; Frantz, G.D.; Pham, T.A.; Dillard-Telm, L.; Tsai, S.P.; Stephan, J.P.; et al. A mouse model of hepatocellular carcinoma: Ectopic expression of fibroblast growth factor 19 in skeletal muscle of transgenic mice. Am. J. Pathol. 2002, 160, 2295-2307. [CrossRef]

260. Miura, S.; Mitsuhashi, N.; Shimizu, H.; Kimura, F.; Yoshidome, H.; Otsuka, M.; Kato, A.; Shida, T.; Okamura, D.; Miyazaki, M. Fibroblast growth factor 19 expression correlates with tumor progression and poorer prognosis of hepatocellular carcinoma. BMC Cancer 2012, 12, 56. [CrossRef]

261. Zhou, M.; Yang, H.; Learned, R.M.; Tian, H.; Ling, L. Non-cell-autonomous activation of IL-6/STAT3 signaling mediates FGF19-driven hepatocarcinogenesis. Nat. Commun. 2017, 8, 15433. [CrossRef]

262. Zhou, M.; Wang, X.; Phung, V.; Lindhout, D.A.; Mondal, K.; Hsu, J.Y.; Yang, H.; Humphrey, M.; Ding, X.; Arora, T.; et al. Separating Tumorigenicity from Bile Acid Regulatory Activity for Endocrine Hormone FGF19. Cancer Res. 2014, 74, 3306-3316. [CrossRef]

263. Zhou, M.; Learned, R.M.; Rossi, S.J.; DePaoli, A.M.; Tian, H.; Ling, L. Engineered FGF19 eliminates bile acid toxicity and lipotoxicity leading to resolution of steatohepatitis and fibrosis in mice. Hepatol. Commun. 2017, 1, 1024-1042. [CrossRef]

264. Zhou, M.; Luo, J.; Chen, M.; Yang, H.; Learned, R.M.; DePaoli, A.M.; Tian, H.; Ling, L. Mouse species-specific control of hepatocarcinogenesis and metabolism by FGF19/FGF15. J. Hepatol. 2017, 66, 1182-1192. [CrossRef]

265. Pearce, S.C.; Al-Jawadi, A.; Kishida, K.; Yu, S.; Hu, M.; Fritzky, L.F.; Edelblum, K.L.; Gao, N.; Ferraris, R.P. Marked differences in tight junction composition and macromolecular permeability among different intestinal cell types. BMC Biol. 2018, 16, 19. [CrossRef]

266. Fasano, A. Intestinal permeability and its regulation by zonulin: Diagnostic and therapeutic implications. Clin. Gastroenterol. Hepatol. 2012, 10, 1096-1100. [CrossRef] [PubMed]

267. Fasano, A. Regulation of intercellular tight junctions by zonula occludens toxin and its eukaryotic analogue zonulin. Ann. N. Y. Acad. Sci. 2000, 915, 214-222. [CrossRef] [PubMed]

268. Wang, W.; Uzzau, S.; Goldblum, S.E.; Fasano, A. Human zonulin, a potential modulator of intestinal tight junctions. J. Cell Sci. 2000, 113 Pt 24, 4435-4440.

269. Sturgeon, C.; Lan, J.; Fasano, A. Zonulin transgenic mice show altered gut permeability and increased morbidity/mortality in the DSS colitis model. Ann. N. Y. Acad. Sci. 2017, 1397, 130-142. [CrossRef]

270. Scheppach, W. Effects of short chain fatty acids on gut morphology and function. Gut 1994, 35, S35-S38. [CrossRef] [PubMed]

271. Wirth, R.; Bodi, N.; Maroti, G.; Bagyanszki, M.; Talapka, P.; Fekete, E.; Bagi, Z.; Kovacs, K.L. Regionally distinct alterations in the composition of the gut microbiota in rats with streptozotocin-induced diabetes. PLoS ONE 2014, 9, e110440. [CrossRef] [PubMed]

272. Graziani, C.; Talocco, C.; De Sire, R.; Petito, V.; Lopetuso, L.R.; Gervasoni, J.; Persichilli, S.; Franceschi, F.; Ojetti, V.; Gasbarrini, A.; et al. Intestinal permeability in physiological and pathological conditions: Major determinants and assessment modalities. Eur. Rev. Med. Pharmacol. Sci. 2019, 23, 795-810. [CrossRef] [PubMed] 
273. Luther, J.; Garber, J.J.; Khalili, H.; Dave, M.; Bale, S.S.; Jindal, R.; Motola, D.L.; Luther, S.; Bohr, S.; Jeoung, S.W.; et al. Hepatic Injury in Nonalcoholic Steatohepatitis Contributes to Altered Intestinal Permeability. Cell. Mol. Gastroenterol. Hepatol. 2015, 1, 222-232. [CrossRef]

274. Thaiss, C.A.; Levy, M.; Grosheva, I.; Zheng, D.; Soffer, E.; Blacher, E.; Braverman, S.; Tengeler, A.C.; Barak, O.; Elazar, M.; et al. Hyperglycemia drives intestinal barrier dysfunction and risk for enteric infection. Science 2018, 359, 1376-1383. [CrossRef]

275. Gao, J.H.; Wen, S.L.; Tong, H.; Wang, C.H.; Yang, W.J.; Tang, S.H.; Yan, Z.P.; Tai, Y.; Ye, C.; Liu, R.; et al. Inhibition of cyclooxygenase-2 alleviates liver cirrhosis via improvement of the dysfunctional gut-liver axis in rats. Am. J. Physiol. 2016, 310, G962-G972. [CrossRef]

276. Cani, P.D.; Bibiloni, R.; Knauf, C.; Waget, A.; Neyrinck, A.M.; Delzenne, N.M.; Burcelin, R. Changes in gut microbiota control metabolic endotoxemia-induced inflammation in high-fat diet-induced obesity and diabetes in mice. Diabetes 2008, 57, 1470-1481. [CrossRef] [PubMed]

277. De Minicis, S.; Agostinelli, L.; Rychlicki, C.; Sorice, G.P.; Saccomanno, S.; Candelaresi, C.; Giaccari, A.; Trozzi, L.; Pierantonelli, I.; Mingarelli, E.; et al. HCC development is associated to peripheral insulin resistance in a mouse model of NASH. PLoS ONE 2014, 9, e97136. [CrossRef] [PubMed]

278. Giorgio, V.; Miele, L.; Principessa, L.; Ferretti, F.; Villa, M.P.; Negro, V.; Grieco, A.; Alisi, A.; Nobili, V. Intestinal permeability is increased in children with non-alcoholic fatty liver disease, and correlates with liver disease severity. Dig. Liver Dis. Off. J. Ital. Soc. Gastroenterol. Ital. Assoc. Stud. Liver 2014, 46, 556-560. [CrossRef] [PubMed]

279. Carpino, G.; Del Ben, M.; Pastori, D.; Carnevale, R.; Baratta, F.; Overi, D.; Francis, H.; Cardinale, V.; Onori, P.; Safarikia, S.; et al. Increased Liver Localization of Lipopolysaccharides in Human and Experimental NAFLD. Hepatology 2019, 10. [CrossRef]

280. Mouries, J.; Brescia, P.; Silvestri, A.; Spadoni, I.; Sorribas, M.; Wiest, R.; Mileti, E.; Galbiati, M.; Invernizzi, P.; Adorini, L.; et al. Microbiota-driven gut vascular barrier disruption is a prerequisite for non-alcoholic steatohepatitis development. J. Hepatol. 2019, 71, 1216-1228. [CrossRef] [PubMed]

281. Miura, K.; Ohnishi, H. Role of gut microbiota and Toll-like receptors in nonalcoholic fatty liver disease. World J. Gastroenterol. 2014, 20, 7381-7391. [CrossRef]

282. Csak, T.; Velayudham, A.; Hritz, I.; Petrasek, J.; Levin, I.; Lippai, D.; Catalano, D.; Mandrekar, P.; Dolganiuc, A.; Kurt-Jones, E.; et al. Deficiency in myeloid differentiation factor-2 and toll-like receptor 4 expression attenuates nonalcoholic steatohepatitis and fibrosis in mice. Am. J. Physiol. 2011, 300, G433-G441. [CrossRef]

283. Miura, K.; Kodama, Y.; Inokuchi, S.; Schnabl, B.; Aoyama, T.; Ohnishi, H.; Olefsky, J.M.; Brenner, D.A.; Seki, E. Toll-like receptor 9 promotes steatohepatitis by induction of interleukin-1beta in mice. Gastroenterology 2010, 139, 323-334. [CrossRef]

284. Fuchs, M.; Sanyal, A.J. Lipotoxicity in NASH. J. Hepatol. 2012, 56, 291-293. [CrossRef]

285. Yu, L.X.; Yan, H.X.; Liu, Q.; Yang, W.; Wu, H.P.; Dong, W.; Tang, L.; Lin, Y.; He, Y.Q.; Zou, S.S.; et al. Endotoxin accumulation prevents carcinogen-induced apoptosis and promotes liver tumorigenesis in rodents. Hepatology 2010, 52, 1322-1333. [CrossRef]

286. Machida, K.; Tsukamoto, H.; Mkrtchyan, H.; Duan, L.; Dynnyk, A.; Liu, H.M.; Asahina, K.; Govindarajan, S.; Ray, R.; Ou, J.H.; et al. Toll-like receptor 4 mediates synergism between alcohol and HCV in hepatic oncogenesis involving stem cell marker Nanog. Proc. Natl. Acad. Sci. USA 2009, 106, 1548-1553. [CrossRef] [PubMed]

287. Dapito, D.H.; Mencin, A.; Gwak, G.Y.; Pradere, J.P.; Jang, M.K.; Mederacke, I.; Caviglia, J.M.; Khiabanian, H.; Adeyemi, A.; Bataller, R.; et al. Promotion of hepatocellular carcinoma by the intestinal microbiota and TLR4. Cancer Cell 2012, 21, 504-516. [CrossRef] [PubMed]

288. Mridha, A.R.; Wree, A.; Robertson, A.A.B.; Yeh, M.M.; Johnson, C.D.; Van Rooyen, D.M.; Haczeyni, F.; Teoh, N.C.; Savard, C.; Ioannou, G.N.; et al. NLRP3 inflammasome blockade reduces liver inflammation and fibrosis in experimental NASH in mice. J. Hepatol. 2017, 66, 1037-1046. [CrossRef] [PubMed]

289. Wree, A.; McGeough, M.D.; Pena, C.A.; Schlattjan, M.; Li, H.; Inzaugarat, M.E.; Messer, K.; Canbay, A.; Hoffman, H.M.; Feldstein, A.E. NLRP3 inflammasome activation is required for fibrosis development in NAFLD. J. Mol. Med. 2014, 92, 1069-1082. [CrossRef]

290. Vandanmagsar, B.; Youm, Y.H.; Ravussin, A.; Galgani, J.E.; Stadler, K.; Mynatt, R.L.; Ravussin, E.; Stephens, J.M.; Dixit, V.D. The NLRP3 inflammasome instigates obesity-induced inflammation and insulin resistance. Nat. Med. 2011, 17, 179-188. [CrossRef] 
291. Stienstra, R.; van Diepen, J.A.; Tack, C.J.; Zaki, M.H.; van de Veerdonk, F.L.; Perera, D.; Neale, G.A.; Hooiveld, G.J.; Hijmans, A.; Vroegrijk, I.; et al. Inflammasome is a central player in the induction of obesity and insulin resistance. Proc. Natl. Acad. Sci. USA 2011, 108, 15324-15329. [CrossRef]

292. Zaki, M.H.; Boyd, K.L.; Vogel, P.; Kastan, M.B.; Lamkanfi, M.; Kanneganti, T.D. The NLRP3 inflammasome protects against loss of epithelial integrity and mortality during experimental colitis. Immunity 2010, 32, 379-391. [CrossRef]

293. Miele, L.; Valenza, V.; La Torre, G.; Montalto, M.; Cammarota, G.; Ricci, R.; Masciana, R.; Forgione, A.; Gabrieli, M.L.; Perotti, G.; et al. Increased intestinal permeability and tight junction alterations in nonalcoholic fatty liver disease. Hepatology 2009, 49, 1877-1887. [CrossRef]

294. Damms-Machado, A.; Louis, S.; Schnitzer, A.; Volynets, V.; Rings, A.; Basrai, M.; Bischoff, S.C. Gut permeability is related to body weight, fatty liver disease, and insulin resistance in obese individuals undergoing weight reduction. Am. J. Clin. Nutr. 2017, 105, 127-135. [CrossRef]

295. Volynets, V.; Kuper, M.A.; Strahl, S.; Maier, I.B.; Spruss, A.; Wagnerberger, S.; Konigsrainer, A.; Bischoff, S.C.; Bergheim, I. Nutrition, intestinal permeability, and blood ethanol levels are altered in patients with nonalcoholic fatty liver disease (NAFLD). Dig. Dis. Sci. 2012, 57, 1932-1941. [CrossRef]

296. Bardella, M.T.; Valenti, L.; Pagliari, C.; Peracchi, M.; Fare, M.; Fracanzani, A.L.; Fargion, S. Searching for coeliac disease in patients with non-alcoholic fatty liver disease. Dig. Liver Dis. 2004, 36, 333-336. [CrossRef] [PubMed]

297. Reilly, N.R.; Lebwohl, B.; Hultcrantz, R.; Green, P.H.; Ludvigsson, J.F. Increased risk of non-alcoholic fatty liver disease after diagnosis of celiac disease. J. Hepatol. 2015, 62, 1405-1411. [CrossRef] [PubMed]

298. Duarte, N.; Coelho, I.C.; Patarrao, R.S.; Almeida, J.I.; Penha-Goncalves, C.; Macedo, M.P. How Inflammation Impinges on NAFLD: A Role for Kupffer Cells. Biomed. Res. Int. 2015, 2015, 984578. [CrossRef]

299. Meli, R.; Mattace Raso, G.; Calignano, A. Role of Innate Immune Response in Non-Alcoholic Fatty Liver Disease: Metabolic Complications and Therapeutic Tools. Front. Immunol. 2014, 5, 177. [CrossRef] [PubMed]

300. Dixon, L.J.; Barnes, M.; Tang, H.; Pritchard, M.T.; Nagy, L.E. Kupffer cells in the liver. Compr. Physiol. 2013, 3, 785-797. [CrossRef]

301. Leroux, A.; Ferrere, G.; Godie, V.; Cailleux, F.; Renoud, M.L.; Gaudin, F.; Naveau, S.; Prevot, S.; Makhzami, S.; Perlemuter, G.; et al. Toxic lipids stored by Kupffer cells correlates with their pro-inflammatory phenotype at an early stage of steatohepatitis. J. Hepatol. 2012, 57, 141-149. [CrossRef]

302. Duarte, N.; Coelho, I.; Holovanchuk, D.; Ines Almeida, J.; Penha-Goncalves, C.; Paula Macedo, M. Dipeptidyl Peptidase-4 Is a Pro-Recovery Mediator During Acute Hepatotoxic Damage and Mirrors Severe Shifts in Kupffer Cells. Hepatol. Commun. 2018, 2, 1080-1094. [CrossRef]

303. Cheng, C.; Tan, J.; Qian, W.; Zhang, L.; Hou, X. Gut inflammation exacerbates hepatic injury in the high-fat diet induced NAFLD mouse: Attention to the gut-vascular barrier dysfunction. Life Sci. 2018, 209, 157-166. [CrossRef]

304. de la Cuesta-Zuluaga, J.; Mueller, N.T.; Corrales-Agudelo, V.; Velasquez-Mejia, E.P.; Carmona, J.A.; Abad, J.M.; Escobar, J.S. Metformin Is Associated With Higher Relative Abundance of Mucin-Degrading Akkermansia muciniphila and Several Short-Chain Fatty Acid-Producing Microbiota in the Gut. Diabetes Care 2017, 40, 54-62. [CrossRef]

305. Xue, Y.; Zhang, H.; Sun, X.; Zhu, M.J. Metformin Improves Ileal Epithelial Barrier Function in Interleukin-10 Deficient Mice. PLOS ONE 2016, 11, e0168670. [CrossRef]

306. Zhou, Z.Y.; Ren, L.W.; Zhan, P.; Yang, H.Y.; Chai, D.D.; Yu, Z.W. Metformin exerts glucose-lowering action in high-fat fed mice via attenuating endotoxemia and enhancing insulin signaling. Acta Pharm. Sin. 2016, 37, 1063-1075. [CrossRef] [PubMed]

307. Yan, X.; Feng, B.; Li, P.; Tang, Z.; Wang, L. Microflora Disturbance during Progression of Glucose Intolerance and Effect of Sitagliptin: An Animal Study. J. Diabetes Res. 2016, 2016, 10. [CrossRef]

308. Zhang, Q.; Xiao, X.; Li, M.; Yu, M.; Ping, F.; Zheng, J.; Wang, T.; Wang, X. Vildagliptin increases butyrate-producing bacteria in the gut of diabetic rats. PLOS ONE 2017, 12, e0184735. [CrossRef] [PubMed]

309. Zhang, Q.; Xiao, X.; Zheng, J.; Li, M.; Yu, M.; Ping, F.; Wang, T.; Wang, X. Featured article: Structure moderation of gut microbiota in liraglutide-treated diabetic male rats. Exp. Biol. Med. 2018, 243, 34-44. [CrossRef] [PubMed] 
310. Lee, D.M.; Battson, M.L.; Jarrell, D.K.; Hou, S.; Ecton, K.E.; Weir, T.L.; Gentile, C.L. SGLT2 inhibition via dapagliflozin improves generalized vascular dysfunction and alters the gut microbiota in type 2 diabetic mice. Cardiovasc. Diabetol. 2018, 17, 62. [CrossRef]

311. Pathak, P.; Xie, C.; Nichols, R.G.; Ferrell, J.M.; Boehme, S.; Krausz, K.W.; Patterson, A.D.; Gonzalez, F.J.; Chiang, J.Y.L. Intestine farnesoid $X$ receptor agonist and the gut microbiota activate G-protein bile acid receptor-1 signaling to improve metabolism. Hepatology 2018, 68, 1574-1588. [CrossRef]

312. Plovier, H.; Everard, A.; Druart, C.; Depommier, C.; Van Hul, M.; Geurts, L.; Chilloux, J.; Ottman, N.; Duparc, T.; Lichtenstein, L.; et al. A purified membrane protein from Akkermansia muciniphila or the pasteurized bacterium improves metabolism in obese and diabetic mice. Nat. Med. 2017, 23, 107-113. [CrossRef]

313. Dao, M.C.; Everard, A.; Aron-Wisnewsky, J.; Sokolovska, N.; Prifti, E.; Verger, E.O.; Kayser, B.D.; Levenez, F.; Chilloux, J.; Hoyles, L.; et al. Akkermansia muciniphila and improved metabolic health during a dietary intervention in obesity: Relationship with gut microbiome richness and ecology. Gut 2016, 65, 426-436. [CrossRef]

314. Depommier, C.; Everard, A.; Druart, C.; Plovier, H.; Van Hul, M.; Vieira-Silva, S.; Falony, G.; Raes, J.; Maiter, D.; Delzenne, N.M.; et al. Supplementation with Akkermansia muciniphila in overweight and obese human volunteers: A proof-of-concept exploratory study. Nat. Med. 2019, 25, 1096-1103. [CrossRef]

315. Suez, J.; Zmora, N.; Zilberman-Schapira, G.; Mor, U.; Dori-Bachash, M.; Bashiardes, S.; Zur, M.; Regev-Lehavi, D.; Ben-Zeev Brik, R.; Federici, S.; et al. Post-Antibiotic Gut Mucosal Microbiome Reconstitution Is Impaired by Probiotics and Improved by Autologous FMT. Cell 2018, 174, 1406-1423. [CrossRef]

316. Vrieze, A.; Van Nood, E.; Holleman, F.; Salojarvi, J.; Kootte, R.S.; Bartelsman, J.F.; Dallinga-Thie, G.M.; Ackermans, M.T.; Serlie, M.J.; Oozeer, R.; et al. Transfer of intestinal microbiota from lean donors increases insulin sensitivity in individuals with metabolic syndrome. Gastroenterology 2012, 143, 913-916. [CrossRef] [PubMed]

(C) 2020 by the authors. Licensee MDPI, Basel, Switzerland. This article is an open access article distributed under the terms and conditions of the Creative Commons Attribution (CC BY) license (http://creativecommons.org/licenses/by/4.0/). 